\title{
New metal and glass finds from the Late Iron Age in South Moravia (CZ). The contribution of citizen science to knowledge of the La Tène settlement structure in the Břeclav Region
}

\author{
Nové nálezy kovových a skleněných předmětů z mladší doby \\ železné na jižní Moravě. Přínos občanské spolupráce k poznání \\ laténského osídlení na Břeclavsku
}

- Petra Golán̆ová*, Balázs Komoróczy, Matěj Kmošek, Eva Kolníková, Marek Vlach, Michaela Zelíková -

\section{KEYWORDS:}

Late Iron Age - metal detector prospection - XRF elemental composition analysis - metal artefacts - coins - glass

\section{ABSTRACT}

The 'Celts Beneath the Pálava Hills' exhibition was installed at the end of the summer of 2020 at the Regional Museum in Mikulov. The museum prepared the exhibition in cooperation with the Moravian Museum and the Institute of Archaeology of the Czech Academy of Sciences, Brno. Along with other unique exhibits, an assemblage of 70 metal artefacts stored in Dolni Dunajovice in the study collection of the Research Centre for the Roman and Great Migration periods of the Institute of Archaeology of the Czech Academy of Sciences, Brno, was chosen to be displayed for this event.

The article presents 47 small artefacts made of copper alloys, 18 coins and five glass artefacts from 17 cadastral units, which enriched the exhibition with a variety of characteristic LT C and D1 finds. They do not form a complete collection, as their common denominator is that they were found in 2011-2017 solely by metal detectorists working together with the archaeologists from the workplace where the finds are stored. These never-before-published artefacts and the qualities of each deserve to be presented both to the public and the professional community. These artefacts include finds which, in the context of the Late Iron Age of south Moravia, are unique objects (including two bronze figurines) that are significant contributions to the clarification and differentiation of the topography of the La Tène settlement structure in the studied region.
* Corresponding author -E-mail address: golanova@phil.muni.cz

\section{Introduction}

The Celts Beneath the Pálava Hills exhibition prepared in cooperation with the Moravian Museum and the Institute of Archaeology of the Czech Academy of Sciences, Brno, was installed at the Regional Museum in Mikulov in 2020. Among other items, a set of 70 small objects from the inventory of metal finds held in the study collection of the Research Centre for the Roman Period and the Migration Period of the Institute of Archaeology of the Czech Academy of Sciences, Brno in Dolní Dunajovice, was selected for this event. These are finds that have not yet been published, and their individual qualities deserve to be made available to the professional public. Not only do the artefacts include those representing highly unique items in the context of the Late Iron Age of south Moravia, they also significantly contribute to the specification and differentiation of the topography of La Tène settlement in the given region.

Although the Břeclav region and especially the narrower territory below the Pavlov Hills are considered to be one of the most intensively researched areas with La Tène settlement in Moravia (mainly due to excavations prior to the construction of the Nové Mlýny waterworks system; for a summary see Čižmář 2002b, 249-271), the increasing number of metal detector finds provide evidence of Late Iron Age settlement (and to a lesser extent perhaps also burial) activities in hitherto unknown places while also enriching our knowledge of individual sites with a range of finds that previous excavations or surface surveys did not capture (cf. Goláňová, Kysela 2019). A systematic detector survey of the Břeclav region or its parts conducted using a uniform professional methodology under institutional control (not only focused on the La Tène period) has not yet taken place. As it is also questionable whether such an endeavour is even within the possibilities of the scientific field, are not small (mostly metal) artefacts discovered by the public and registered at individual archaeological workplaces potentially the most representative source for the archaeological topography of the respective era?

This article presents a total of 47 artefacts made of copper alloys, 18 coins and five glass specimens, which enriched the exhibition with a characteristic spectrum of finds from survey. While they do not represent a coherent assemblage, their unifying characteristic is the fact that they were found in 2011-2017 exclusively by so-called detectorists cooperating for years with the workplace where objects are stored (generally on the issue of detectorists - collaborators with archaeological workplaces, see Komoróczy et al. 2019a). There is no uniform approach in Moravian archaeology to the publication of finds from detector surveys conducted by the public and regularly handed over to authorised organisations. More than 10 years ago, M. Čižmářrs initiated attempt to preliminarily publish detector finds (Čižmář 


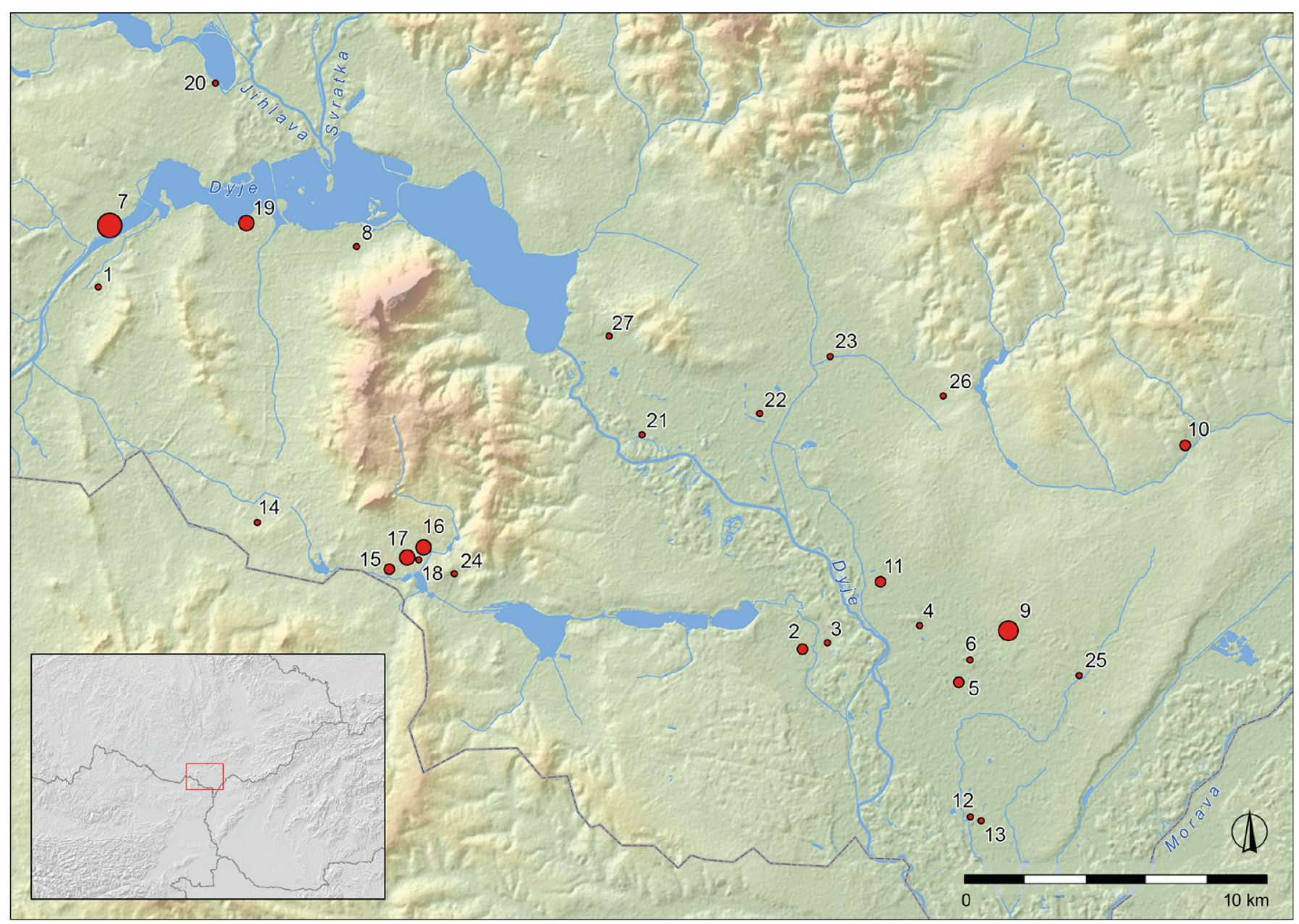

Fig. 1. Geographical distribution of the finds included in the catalogue part of the text. Source of map base: SRTM 30m (c) NASA.

1 Brod nad Dyjí - Pod Silnicí; 2 Břeclav - Hrudy; 3 Břeclav - Lúbež; 4 Břeclav - Nivečky; 5 Břeclav - Přední čtvrtky; 6 Břeclav - Žleby; 7 Drnholec - Roviny; 8 Horní Věstonice Pod Transformátorem; 9 Hrušky - Tvrdonické podsedky; 10 Josefov - Pod Rozhranskem; 11 Ladná - Padělky; 12 Lanžhot - Horní Štěpnice; 13 Lanžhot - Padělky; 14 Mikulov Liščí hony; 15 Mikulov - Na Mikulovsku; 16 Mikulov - Nad Valtickou silnicí; 17 Mikulov - U Aleje; 18 Mikulov - U Vodárny; 19 Mušov - Na Pískách; 20 Pasohlávky - Drobné př́děly; 21 Př́tluky - U Hluboké vody; 22 Rakvice - Díly; 23 Rakvice - Rybníčky; 24 Sedlec - Za Čelovským; 25 Tvrdonice - Pole od Týnecka; 26 Velké Bílovice - Od Čejkovska; 27 Zaječí - U Obalovny.

Obr. 1. Mapa tratí, z nichž pocházejí nálezy zařazené do katalogové části textu. Zdroj mapového podkladu: SRTM 30m (c) NASA.

1 Brod nad Dyjí - Pod Silnicí; 2 Břeclav - Hrudy; 3 Břeclav - Lúbež; 4 Břeclav - Nivečky; 5 Břeclav - Přední čtvrtky; 6 Břeclav - Žleby; 7 Drnholec - Roviny; 8 Horní Věstonice Pod Transformátorem; 9 Hrušky - Tvrdonické podsedky; 10 Josefov - Pod Rozhranskem; 11 Ladná - Padělky; 12 Lanžhot - Horní Štěpnice; 13 Lanžhot - Padělky; 14 Mikulov Liščí hony; 15 Mikulov - Na Mikulovsku; 16 Mikulov - Nad Valtickou silnicí; 17 Mikulov - U Aleje; 18 Mikulov - U Vodárny; 19 Mušov - Na Pískách; 20 Pasohlávky - Drobné př́́děly; 21 Př́tluky - U Hluboké vody; 22 Rakvice - Díly; 23 Rakvice - Rybníčky; 24 Sedlec - Za Čelovským; 25 Tvrdonice - Pole od Týnecka; 26 Velké Bílovice - Od Čejkovska; 27 ZaječíU Obalovny.

et al. 2008; 2010a; 2011) was apparently inspired by the pattern of an older, 'pre-restrictive' era of Austrian archaeology (i.e., until 1999, see Karl 2019), but there were no details and time differentiation corresponding to previously published articles in the journal Fundberichte aus Österreich. Later, this plan was not continued and the predominant form of publishing detector finds is either reports on individual artefacts (e.g., Kuča, Ženožičková 2017, 192-193), or thematically, mostly inventory or synthesising works arranged according to a certain category of finds (e.g., Čižmářová 2014, 655-665). The Research Centre for the Roman Period and the Migration Period of the Institute of Archaeology of the Czech Academy of Sciences, Brno, has been dealing with detectorist finds for a long time, attempting to transparently develop all methodological aspects of their acquisition, documentation and evaluation (see e.g., Komoróczy et al. 2014; 2017; 2019b). Therefore, the Centre could also contribute to the mentioned exhibition project with this collection. Apparently, a similar approach is also being applied in a number of institutions that care for collections in the region in question and elsewhere. However, the information and utilisation of the data obtained by them for topographic or other analytical processing will probably not improve until Czech archaeology adopts some form of elementary publication standard or generally binding data storage in a system environment corresponding to the British Portable Antiquity Scheme (PAS; see, e.g., Bland 2005).

The finds published here come from a total of 17 cadastral areas (Fig. 1), of which 14 are located in the district of Břeclav, two in the southern part of the Brno-venkov district (Pasohlávky, Mušov), and one is in the district of Hodonín (Josefov). Within these cadastral areas, they were scattered into 27 locations, though this fact does not necessarily mean, without further detailed analysis, that they represent the same number of separate La Tène sites. The vast majority of the represented locations show a multicultural character in the assemblages of detector finds (Tab. 1). In the collection presented here we find a characteristic spectrum of finds which, thanks to the use of detectors, we know from La Tène lowland (e.g., Čižmář et al. 2008; 2010b; Danielisová et al. 2018a; Goláňová, Kysela 2019; Vích 2017) and highland sites (e.g., Čižmář, 


\begin{tabular}{|c|c|c|c|c|c|c|}
\hline Location & Eneolithic & Bronze Age & Iron Age & $\begin{array}{l}\text { Roman } \\
\text { period }\end{array}$ & $\begin{array}{l}\text { Migration } \\
\text { Period }\end{array}$ & References \\
\hline Brod nad Dyjí - Pod Silnicí & - & + & + & + & - & \\
\hline Břeclav - Hrudy & - & + & + & + & + & \\
\hline Břeclav - Lúbež & - & + & + & + & - & \\
\hline Břeclav - Nivečky & - & + & + & + & - & Čižmářová 2004, 155 \\
\hline Břeclav - Přední čtvrtky & - & - & + & + & - & Čižmářová 2004, 155 \\
\hline Břeclav - Žleby & - & - & + & - & - & Čižmářová 2004, 155 \\
\hline Drnholec - Roviny & - & + & + & + & + & $\begin{array}{l}\text { Čižmář et al. 2010a, 129; } \\
\text { Čižmářová 2004, 172; } \\
\text { Jelínková, Kavánová 2002, 274; } \\
\text { Komoróczy et al. 2019b }\end{array}$ \\
\hline Horní Věstonice - Pod Transformátorem & - & - & + & - & - & \\
\hline Hrušky - Tvrdonické podsedky & + & - & + & + & - & \\
\hline Josefov - Pod Rozhranskem & - & + & + & + & - & Čižmářová 2004, 202 \\
\hline Ladná - Padělky & - & - & + & - & - & Čižmářová 2004, 218 \\
\hline Lanžhot - Horní Štěpnice & - & - & + & + & - & \\
\hline Lanžhot - Padělky & - & - & + & - & - & Čižmářová 2004, 218 \\
\hline Mikulov - Liščí hony & - & + & + & - & - & \\
\hline $\begin{array}{l}\text { Mikulov - Na Mikulovsku, Nad Valtickou } \\
\text { silnicí, U Aleje, U Vodárny }\end{array}$ & - & + & + & + & + & Čižmářová 2004, 238 \\
\hline Mušov - Na Pískách & - & + & + & + & + & $\begin{array}{l}\text { Čižmářová 2004, 250; } \\
\text { Jelínková, Kavánová 2002, } \\
\text { 277-278 }\end{array}$ \\
\hline Pasohlávky - Drobné př́íděly & - & + & + & + & + & \\
\hline Přítluky - U Hluboké vody & - & + & + & + & - & \\
\hline Rakvice - Díly, Rybníčky & - & - & + & + & - & Čižmářová 2004, 296 \\
\hline Sedlec - Za Čelovským & - & - & + & - & - & \\
\hline Tvrdonice - Pole od Týnecka & - & - & + & + & - & Čižmářová 2004, 327 \\
\hline Velké Bílovice - Od Čejkovska & - & - & + & - & - & \\
\hline Zaječí - U Obalovny & - & - & + & + & - & \\
\hline
\end{tabular}

Tab. 1. The principal archaeological periods (Eneolithic to the Migration period) represented in the individual locations by the metal objects obtained by detectorists collaborating with the Research Centre for the Roman Period and the Migration Period of the Institute of Archaeology of the Czech Academy of Sciences, Brno and presented in the catalogue.

Tab. 1. Zastoupení hlavních metalických etap v kolekcích kovových předmětů získaných detektorářskými spolupracovníky Střediska pro výzkum doby římské a stěhování národů Archeologického ústavu AV ČR, Brno, v. v. i. vtratích, z nichž pocházejí do katalogu zahrnuté artefakty.

Salaš 2009; Goláňová, Navrátil 2017). In the majority of cases, the contexts of these finds cannot yet be clearly defined (with the exception of the Drnholec site, the 'Roviny' location, which is better known in the literature as the 'Holenická pole' location; cf. Komoróczy et al. 2019b), whereas the forms represented here repeatedly appear in detector collections from purely La Tène, and even more frequently from repeatedly occupied sites (cf. in addition to Drnholec, also the sites in the work of Čižmář et al. 2010a; 2011).

\section{Catalogue of finds}

The catalogue of finds lists all artefacts that were selected as exhibits for the aforementioned Celts Beneath the Pálava Hills exhibition. The catalogue is organised by individual locations and its structure and descriptive system corresponds to the form in which the finds made by detectorists collaboratorating with the Research Centre for the Roman Period and the Migration Period of the Institute of Archaeology of the Czech Academy of Sciences, Brno, are registered in the relational attribute and spatial database at this workplace (cf. Komoróczy et al. 2017).
1. Brod nad Dyjí (Břeclav district) 'Pod Silnicí' (Fig. 2: 1) Ring with biconvex cross-section, ground to a circular cross-section in one place by wear.

Diameter: $16.8 \mathrm{~mm}$, inner diameter: $10.5 \mathrm{~mm}$, weight: $2 \mathrm{~g}$ Material (XRF surface measurement, \%): Fe 3; Cu 29.1; Sn 30.4; $\mathrm{Pb} 37.5$

Finder: Martin Wollmuth

Held at: Institute of Archaeology of the Czech Academy of Sciences, Brno (inv. no. 612642-3/11)

2. Břeclav (Břeclav district) 'Hrudy' (Fig. 2: 2)

A fragment of a belt chain link damaged by fire. A model with a globular central element lined on each side by ribs followed by bar-like tapering and rectangular side plates (with three chainlet holes in each). Bulge on the side of the plate and on one of its surfaces; deformed, porous.

Preserved length of link: $26.6 \mathrm{~mm}$, cross-section of central part: c. $10.2 \times 10.8 \mathrm{~mm}$, original width of plate: c. $15.4 \mathrm{~mm}$, weight: $7.49 \mathrm{~g}$ Material (XRF surface measurement, \%): Fe 0.46; $\mathrm{Cu} 42.01$; 
New metal and glass finds from the Late Iron Age in South Moravia (CZ). The contribution of citizen science to knowledge... Goláňová, P., Komoróczy, B., Kmošek, M., Kolníková, E., Vlach, M., Zelíková, M. • Přehled výzkumů 61/2, 2020 • 9-41

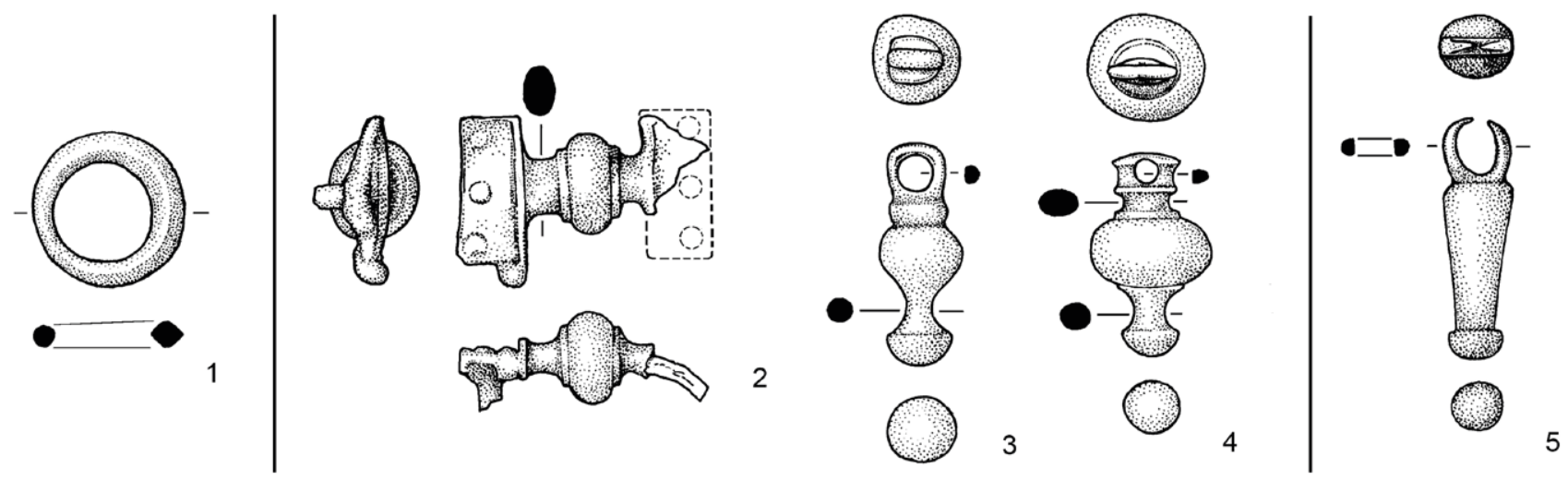

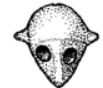
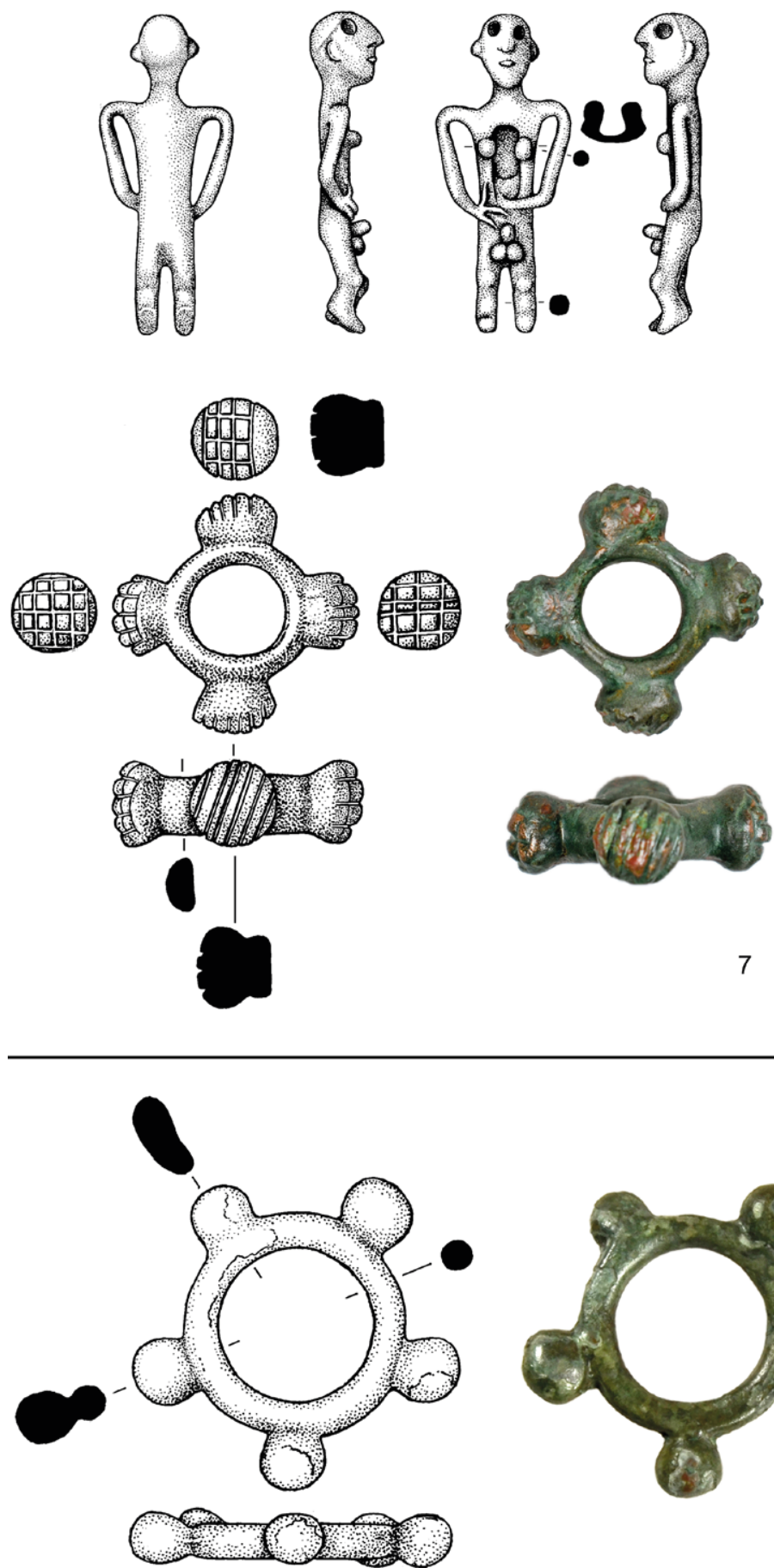
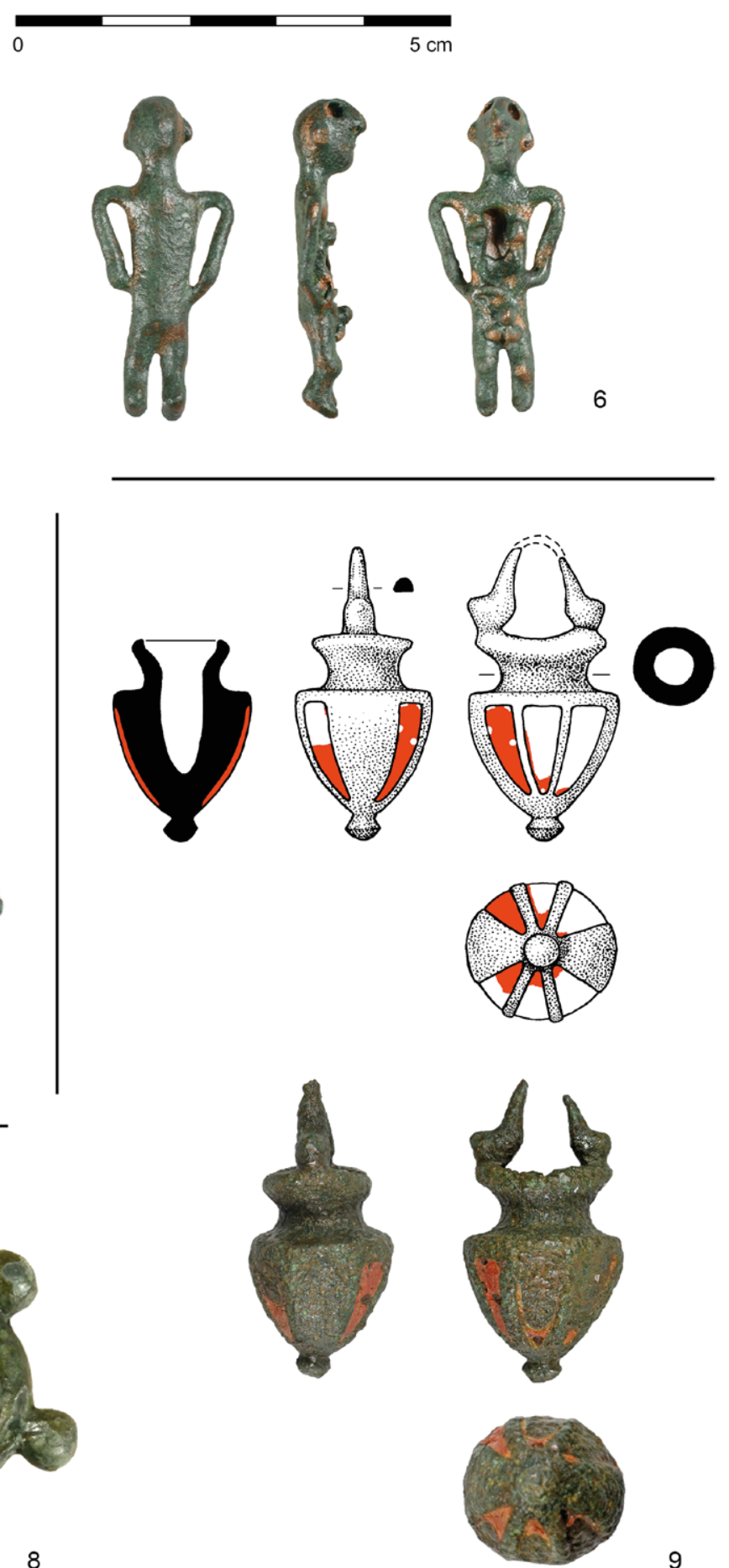
Zn 0.12; Sn 22.49; Pb 34.09; Ag 0.21; Sb 0.19; Bi $0.31 \mathrm{Zr} 0.03$ Finder: Štěpán Kurial

Held at: Institute of Archaeology of the Czech Academy of Sciences, Brno (inv. no. 613584-1/13)

\section{Břeclav (Břeclav district) 'Hrudy' (Fig. 2: 3)}

Conical vase-shaped pendant with a shaft eyelet, offset by a single thick rib. The lower part continues in an asymmetrical cone with a hemispherical termination.

Length: $26.6 \mathrm{~mm}$, maximum width: $10 \mathrm{~mm}$, outer dimensions of rectangular eyelet with rounded corners: $6.7 \times 6.9 \mathrm{~mm}$, inner diameter: $3.4 \mathrm{~mm}$, weight: $6.34 \mathrm{~g}$

Material (XRF surface measurement, \%): $\mathrm{Fe} 0.62$; $\mathrm{Cu} 24.57 ; \mathrm{Zn} \mathrm{0.1}$; Sn 31.32; Pb 41.09; Sb 0.26; Ti 0.34; Bi 1.6; Zr 0.03; Cr 0.13; V 0.11 Finder: Zdeněk Kovařík

Held at: Institute of Archaeology of the Czech Academy of Sciences, Brno (inv. no. 613584-2/13)

\section{Břeclav (Břeclav district) 'Hrudy' (Fig. 2: 4)}

Conical vase-shaped pendant with a shaft eyelet. The rectangular suspension piece is lined with two ribs and the circular chainlet hole has a diameter of $2 \mathrm{~mm}$; the suspension piece is separated from the body of the pendant by a thin neck. The actual body of the pendant consists of a slightly flattened sphere flanked by ribs on the sides. The lower conical part ends with a hemispherical knob.

Length: $21.8 \mathrm{~mm}$, eyelet dimensions: $7.4 \times 3.7 \mathrm{~mm}$, pendant body cross-section: $12.2 \times 11.4 \mathrm{~mm}$, knob cross-section: $6 \mathrm{~mm}$, weight: $7.08 \mathrm{~g}$

Material (XRF surface measurement, \%): $\mathrm{Fe} 0.2 ; \mathrm{Cu}$ 49.36; Zn 0.22; Sn 16.7; Pb 32.24; Ag 0.22; Sb 0.2; Ti 0.37; Bi 0.18; V 0.20 Finder: Zdeněk Kovař́k

Held at: Institute of Archaeology of the Czech Academy of Sciences, Brno (inv. no. 613584-3/13)

\section{Břeclav (Břeclav district) 'Lúbež’ (Fig. 2: 6)}

Anthropomorphic figurine of a standing human with arms folded at the abdomen and a hole in the chest.

Height: $36 \mathrm{~mm}$, maximum width: $8.2 \mathrm{~mm}$, weight: $6.36 \mathrm{~g}$

Material (XRF surface measurement, \%): Si 6.14; Fe 0.17; Cu 52; Sn 9.23; Pb 30.84; S 1.37; Au 0.26

Finder: Lukáš Kotásek

Held at: Institute of Archaeology of the Czech Academy of Sciences, Brno (inv. no. 613584-6/16)

\section{Břeclav (Břeclav district) 'Lúbež’ (Fig. 2: 7)}

Ring with four decorated knobs. Knobs decorated with grooves, with three of them featuring a grid pattern composed of grooves $(5 \times 4.4 \times 3.5 \times 3)$, the other has only six parallel grooves.

Maximum diameter with knobs: $28 \mathrm{~mm}$, outer diameter of ring: $17 \mathrm{~mm}$, inner diameter of ring: $10.7 \mathrm{~mm}$, ring cross-section (width): $6 \mathrm{~mm}$, diameter of knobs: $9.7 \mathrm{~mm}$, height of knobs: c. $6 \mathrm{~mm}$, weight: $17.17 \mathrm{~g}$

Material (XRF surface measurement, \%): Fe 0.09; Cu 51.52; $\mathrm{Sn} 25.93$; $\mathrm{Pb} 22.14$; $\mathrm{Sb} 0.32$

Finder: Lubomír Svoboda
Held at: Institute of Archaeology of the Czech Academy of Sciences, Brno (inv. no. 613584-7/16)

\section{Břeclav (Břeclav district) 'Nivečky’ (Fig. 2: 5)}

Drop-shaped pendant from a belt. Wider part at the eyelet (here slightly flattened), ending in the tapered part with a button. Damaged eyelet in the shape of a ring (worn by wear).

Preserved length $25.8 \mathrm{~mm}$, max. diameter $7.6 \mathrm{~mm}$, button diameter $5.8 \mathrm{~mm}$, outer diameter of eyelet $7 \mathrm{~mm}$, max. cross-section $1.8 \mathrm{~mm}$ Material (XRF surface measurement, \%): Fe 1.07; Cu 37.44; Zn 0.35; Sn 16.04; Pb 43.49; Ni 0.14; Sb 1.02; Ti 0.23; Bi 0.2; Zr 0.03 Finder: Lukáš Kotásek

Held at: Institute of Archaeology of the Czech Academy of Sciences, Brno (inv. no. 613584-1/17)

\section{Břeclav (Břeclav district) 'Přední čtvrtky' (Fig. 2: 8)}

Ring with five pea-shaped knobs. One knob is smaller, thinner and bent forward.

Outer diameter of ring: $25.4 \mathrm{~mm}$, inner diameter of ring: $17.5 \mathrm{~mm}$, maximum width: $37.5 \mathrm{~mm}$, width of knobs: $7.6 \mathrm{~mm}$ on the level of the ring and $6.5 \mathrm{~mm}$ on the axis of the ring, height of knob: $7 \mathrm{~mm}$, diameter of ring wire: $3.5-3.9 \mathrm{~mm}$, weight: $13.7 \mathrm{~g}$

Material (XRF surface measurement, \%): Fe 2.35; Cu 26.78; Zn 0.09; Sn 32.66; Pb 36.23; Ag 0.73; Ni 0.13; Sb 0.80; Bi 0.41; Zr 0.03 Finder: Zdeněk Omelka

Held at: Institute of Archaeology of the Czech Academy of Sciences, Brno (inv. no. 613584-4/14)

\section{Břeclav (Břeclav district) 'Přední čtvrtky' (Fig. 2: 9)}

Situla-shaped pendant decorated with enamel. A partially hollow pendant with the body of a vessel decorated with three strips of red enamel on both sides; the vessel body on the sides is undecorated. The enamel is embedded in shallow depressions and is only partially preserved. The walls of the vessel face a pointed end featuring a button-shaped protrusion. A handle set on the rim of the vessel has reinforced ends, broken off at the arch/ suspension.

Height: $33.1 \mathrm{~mm}$, maximum width: $17.4 \mathrm{~mm}$, weight: $16.27 \mathrm{~g}$

Material (XRF surface measurement, \%): Fe 0.79; Cu 38.91; Zn 0.45; Sn 28.03; Pb 30.19; Ag 0.41; Sb 0.34; Bi 0.87; Zr 0.02 Finder: Lukáš Kotásek

Held at: Institute of Archaeology of the Czech Academy of Sciences, Brno (inv. no. 613584-5/16)

\section{Břeclav (Břeclav district) ‘Žleby’ (Fig. 6: 1)}

Boii Celts, Au 1/8 stater, Athena Alkidemos type, first half of the $2^{\text {nd }}$ century BC.

Obverse: Irregular hump

Reverse: Figure of Athena Alkidemos type warrior to the left Lit.: Paulsen 1933, no. 134

$0.96 \mathrm{~g}, 8.71-8.73 \mathrm{~mm}$, thickness $1.80 \mathrm{~mm}$, preservation level 3 Material (XRF surface measurement, \%): Fe 0.17; Cu 0.9; Ag 3.26; Ni 0.07; Au 95.61

Finder: Lukáš Kotásek

Held at: Institute of Archaeology of the Czech Academy of Sciences, Brno (inv. no. 613584-2/16) 
New metal and glass finds from the Late Iron Age in South Moravia (CZ). The contribution of citizen science to knowledge... Goláňová, P., Komoróczy, B., Kmošek, M., Kolníková, E., Vlach, M., Zelíková, M. • Přehled výzkumů 61/2, 2020 • 9-41
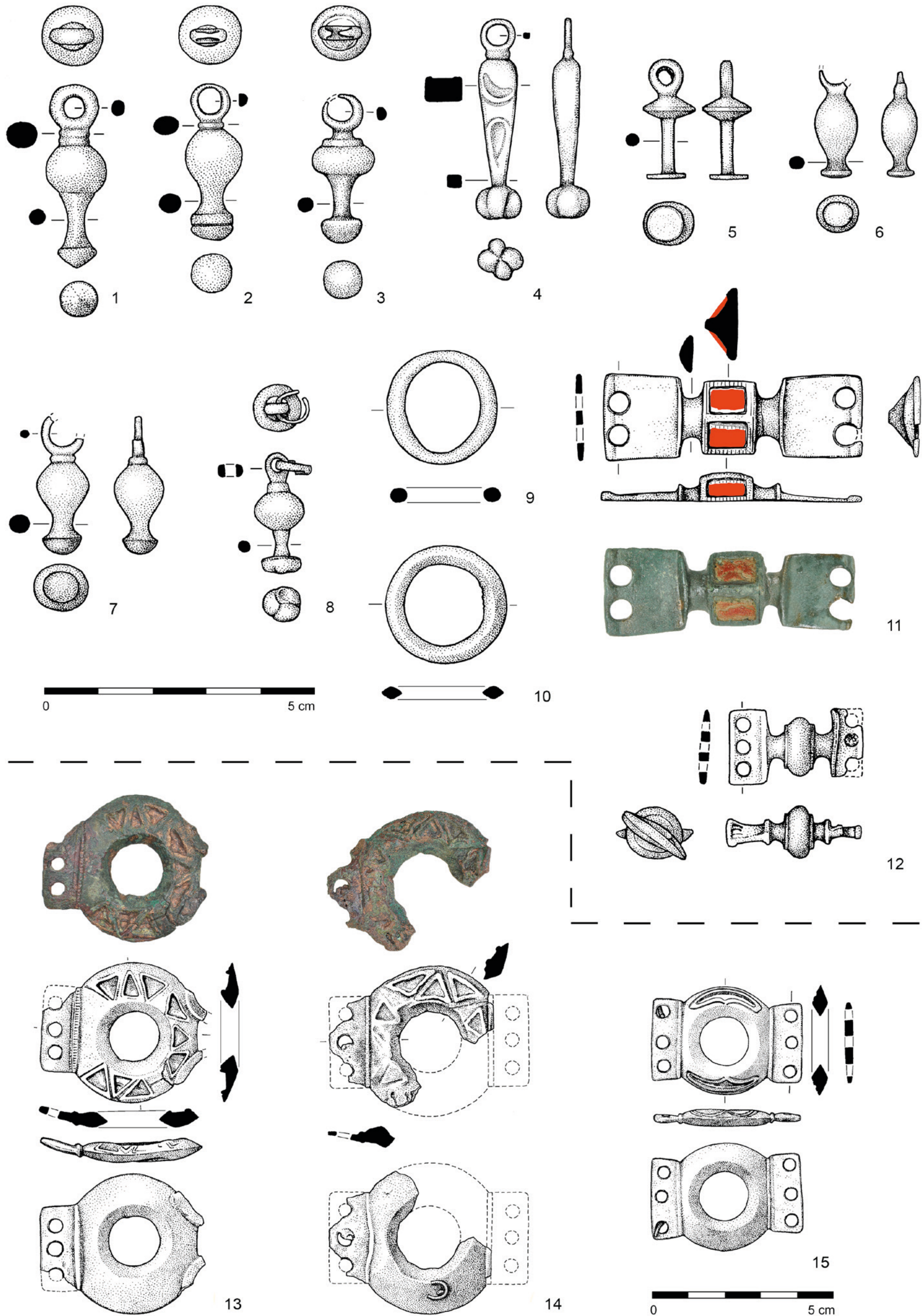
11. Drnholec (Břeclav district) 'Roviny’ (Fig. 3: 11)

A nearly completely preserved belt chain link with approximately square plates on the sides, each with two chainlet holes, in one plate one of the holes deformed by wear. The middle part of the link is rectangular and 'roof-shaped'. In the central part of the triangular cross-section, two rectangular depressions measuring $8 \times 5.6 \mathrm{~mm}$ are filled with red enamel. The reverse part is completely flat.

Lit.: Komoróczy et al. 2019b, Fig. 16: 16

Length: $47.8 \mathrm{~mm}$, dimensions of side plates: $14.6 \times 16.2 \mathrm{~mm}$, diameter of openings in side plates: $3.8 \mathrm{~mm}$, weight: $9.36 \mathrm{~g}$

Material (XRF surface measurement, \%): $\mathrm{Fe} 0.44 ; \mathrm{Cu} 37.1$; Sn 28.38; Pb 33.26; Ni 0.12; Sb 0.58; Au 0.13

Finders: František Kosour, Martin Wollmuth

Held at: Institute of Archaeology of the Czech Academy of Sciences, Brno (inv. no. 632520-45/13)

\section{Drnholec (Břeclav district) 'Roviny' (Fig. 3: 13)}

Link (belt hook?) from chain belt damaged by fire. The annular central part is decorated on the front side with deep irregular triangular notches (originally perhaps depressions for holding enamel, though no trace of it has been preserved). Preserved on one side is a rectangular plate originally with three chainlet holes, separated from the annular part by a thin relief rib that also runs on the reverse side. The outer rib is decorated and lined on the sides with strips of barely discernible short grooves. There must have been a different terminal on the side opposite the rectangular plate (the hook?), since two arms (now broken off) protrude from the ring and the annular central part at this point has its outer circumference (a side plate is not connected to it).

Lit.: Komoróczy et al. 2019b, Fig. 16: 15

Diameter of the annular part: c. $40 \mathrm{~mm}$, diameter of the central opening: $14 \mathrm{~mm}$, dimensions of rectangular plate: $24 \times 10 \mathrm{~mm}$, diameter of chainlet holes: $3.4 \mathrm{~mm}$, diameter of preserved arm: c. $35 \mathrm{~mm}$, weight: $25.3 \mathrm{~g}$

Material (XRF surface measurement, \%): Fe 0.38; Cu 54.18; Sn 16.11; Pb 28.43; Sb 0.9

Finders: František Kosour

Held at: Institute of Archaeology of the Czech Academy of Sciences, Brno (inv. no. 632520-58/13)

\section{Drnholec (Břeclav district) 'Roviny' (Fig. 3: 14)}

Fragment of a massive belt link damaged by heat. The originally annular central part is decorated on the front with embossed triangular notches. One side part is not preserved, the other is a heavily damaged side plate, originally with three chainlet holes (now only one preserved, with a fused fragment of a chainlet link); the side plate is separated from the annular part by a thin relief rib that also runs on the reverse side. On the back of the annular part, two fragments of a bent wire (chainlet links?) are fused in one place. The dimensions, number of holes for chainlets and decoration correspond to the link of belt no. 12 (inv. no. 632520-58/13). Lit.: Komoróczy et al. 2019b, Fig. 16: 15

Diameter of annular part: $45.9 \mathrm{~mm}$, diameter of chainlet hole: c. $4 \mathrm{~mm}$, wire lengths: c. 7 and $10 \mathrm{~mm}$, wire diameter: $1 \mathrm{~mm}$, weight: $19.2 \mathrm{~g}$
Material (XRF surface measurement, \%): Fe 0.57; Cu 42.68; Sn 12.81; Pb 43.25; Ag 0.19; Sb 0.48

Finder: František Kosour

Held at: Institute of Archaeology of the Czech Academy of Sciences, Brno (inv. no. 632520-65/14)

\section{Drnholec (Břeclav district) 'Roviny' (Fig. 3: 15)}

Fully preserved belt link. The middle part is annular with a rhombic cross section. On the outside, the annular part is decorated at the top and bottom with engraved arches, perhaps originally for filling with enamel. On the sides are narrow rectangular plates, each with three chainlet holes. The side plates are separated from the annular part by a thin relief rib, which also runs on the reverse side. A fragment of bronze wire (chainlet link) is preserved in one of the edge chainlet holes.

Lit.: Komoróczy et al. 2019b, Fig. 16: 12

Outer diameter of ring part: $30 \mathrm{~mm}$, inner diameter of annular part: $13.2 \mathrm{~mm}$, maximum thickness: $4.5 \mathrm{~mm}$, plate dimensions: $22.4 \times 7.4 \mathrm{~mm}$ and $22.8 \times 7.4 \mathrm{~mm}$, plate thickness: $2.7 \mathrm{~mm}$, chainlet hole diameter: $3.4 \mathrm{~mm}$, diameter of preserved wire: $1.1 \mathrm{~mm}$, weight: $16.9 \mathrm{~g}$

Material (XRF surface measurement, \%): $\mathrm{Fe}$ 0.57; $\mathrm{Cu} 42.68$; Sn 12.81; Pb 43.25; Ag 0.19; Sb 0.48

Finder: František Kosour

Held at: Institute of Archaeology of the Czech Academy of Sciences, Brno (inv. no. 632520-64/14)

\section{Drnholec (Břeclav district) 'Roviny’ (Fig. 3: 12)}

Fragment of a link from a belt chain, slightly deformed. A model with rectangular side plates with three chainlet holes and a central globular element flanked by ribs on each side followed by bar-like tapering. The rest of the chainlet link is in the only preserved (middle) hole on the fragmented side plate.

Lit.: Komoróczy et al. 2019b, Fig. 16: 13

Dimensions of preserved plate: $14.3 \times 7.2 \mathrm{~mm}$, plate thickness: $1.5 \mathrm{~mm}$, hole diameter: $2 \mathrm{~mm}$, cross-section of middle part: c. $10.2 \times 10.8 \mathrm{~mm}$, link length: $26.3 \mathrm{~mm}$, diameter of connecting wire: c. $1 \mathrm{~mm}$, weight: $6.6 \mathrm{~g}$

Material (XRF surface measurement, \%): Fe 0.18; Cu 68; Sn 14.27; $\mathrm{Pb}$ 16.38; Ag 0.21; Ni 0.11; Sb 0.17; Bi 0.4

Finder: František Kosour

Held at: Institute of Archaeology of the Czech Academy of Sciences, Brno (inv. no. 632520-66/14)

\section{Drnholec (Břeclav district) 'Roviny' (Fig. 3: 1)}

Conical vase-shaped pendant with a massive shaft eyelet separated from the globular part by two small ribs. The lower cone is offset from the large globular part, ending conically with a slight offset. Lit.: Komoróczy et al. 2019b, Fig. 16: 19

Outer diameter of eyelet: $8.8 \mathrm{~mm}$, inner diameter of eyelet: $3.7 \mathrm{~mm}$, diameter of globular part: $11.2 \mathrm{~mm}$, diameter of conical end: $7.7 \mathrm{~mm}$, overall length: $39.5 \mathrm{~mm}$, weight: $9.38 \mathrm{~g}$

Material (XRF surface measurement, \%): $\mathrm{Fe} \mathrm{0.2;} \mathrm{Cu}$ 60.17; Sn 19.45; Pb 19.74; Ni 0.06; Ti 0.2; Au 0.19

Finder: František Kosour

Held at: Institute of Archaeology of the Czech Academy of Sciences, Brno (inv. no. 632520-43/13) 


\section{Drnholec (Břeclav district) 'Roviny' (Fig. 3: 2)}

Conical vase-shaped pendant with a shaft eyelet, offset from the central globular part by a single slender rib. Ring eyelet with plano-convex cross-section, thinned in one place by wear. The lower cone ends with a lenticular knob with a horizontal groove. Lit.: Komoróczy et al. 2019b, Fig. 16: 17

Diameter of globular part: $10.8 \mathrm{~mm}$, diameter of end knob: $7.5 \mathrm{~mm}$, outer diameter of eyelet: $7.4 \mathrm{~mm}$, inner diameter of eyelet: $4.2 \mathrm{~mm}$, weight: $8.3 \mathrm{~g}$

Material (XRF surface measurement, \%): Fe 0.39; $\mathrm{Cu} 31.99$; Sn 25.19; Pb 40.18; Ag 0.67; Sb 0.16; Bi 0.91

Finder: František Kosour

Held at: Institute of Archaeology of the Czech Academy of Sciences, Brno (inv. no. 632520-67/13)

\section{Drnholec (Břeclav district) 'Roviny' (Fig. 3: 3)}

Strongly articulated conical pendant. The eyelet, a section of which is worn away, is separated from the globular part and flanking rib by a neck. The hemispherical lower end is connected to the globular part by a conical middle part.

Lit.: Komoróczy et al. 2019b, Fig. 16: 18

Maximum diameter of globular part: $11 \mathrm{~mm}$, outer diameter of eyelet: $7.8 \mathrm{~mm}$, terminal diameter: $7.7 \mathrm{~mm}$, weight: $7.07 \mathrm{~g}$

Material (XRF surface measurement, \%): Fe 0.2; Cu 70.79; Zn 0.01; Sn 8.15; Pb 20.26; Ni 0.05; Sb 0.18

Finder: František Kosour

Held at: Institute of Archaeology of the Czech Academy of Sciences, Brno (inv. no. 632520-68/13)

\section{Drnholec (Břeclav district) 'Roviny' (Fig. 3: 4)}

Belt pendant. The body of the pendant is drop-shaped in front view, but has a rectangular cross-section; at the end it is provided with a globular shape divided by deep notches into 4 fields (resembling a swirling four-leaf clover when viewed from below). The ring eyelet is divided from the body by a small rib. The front of the body has depressions (probably for filling with enamel) in the shape of a semicircle and a drop pointing upwards.

Lit.: Komoróczy et al. 2019b, Fig. 16: 21

Length of pendant: $37.8 \mathrm{~mm}$, maximum body dimensions: $7.7 \times 5 \mathrm{~mm}$, diameter of lower end: $8 \times 7 \mathrm{~mm}$, outer diameter of eyelet: $6.5 \mathrm{~mm}$, inner diameter of eyelet: $3 \mathrm{~mm}$, weight: $6.86 \mathrm{~g}$ Material (XRF surface measurement, \%): Fe 0.16; Cu 55.93; Sn12.78; Pb 29.98; Ag 0.25; Sb 0.62

Finder: František Kosour

Held at: Institute of Archaeology of the Czech Academy of Sciences, Brno (inv. no. 632520-69/13)

\section{Drnholec (Břeclav district) 'Roviny' (Fig. 3: 5)}

Belt pendant of a bobbin-shaped form with a relatively massive eyelet. The eyelet is connected to a transverse flat disc, while the middle part is a slightly tapering bar ending with a smaller disc. Lit.: Komoróczy et al. 2019b, Fig. 16: 22

Length of pendant: $22.6 \mathrm{~mm}$, outer diameter of eyelet: $6.6 \mathrm{~mm}$, inner diameter of eyelet: $2.5 \mathrm{~mm}$, diameter of larger disc: $9.8 \mathrm{~mm}$, diameter of smaller disc: $7.6 \mathrm{~mm}$, weight: $3.06 \mathrm{~g}$

Material (XRF surface measurement, \%): $\mathrm{Fe} 0.06$; Cu 71.64; Sn 9.32; Pb 17.3; Ag 0.28; Sb 0.45; Bi 0.19

Finder: František Kosour

Held at: Institute of Archaeology of the Czech Academy of Sciences, Brno (inv. no. 632520-70/13)

\section{Drnholec (Břeclav district) 'Roviny' (Fig. 3: 6)}

Vase-shaped pendant with a flat discoid terminal of an oval cross-section. The shaft eyelet connected to the upper part is mostly broken off.

Lit.: Komoróczy et al. 2019b, Fig. 16: 23

Preserved length: $20.2 \mathrm{~mm}$, diameter of the upper part: $8.3 \times 7.3 \mathrm{~mm}$, diameter of lower end: $6 \times 5 \mathrm{~mm}$, weight: $3.8 \mathrm{~g}$

Material (XRF surface measurement, \%): Cu 57.21; Sn 5.33; $\mathrm{Pb}$ 35.2; Ag 0.34; Sb 1.42

Finder: František Kosour

Held at: Institute of Archaeology of the Czech Academy of Sciences, Brno (inv. no. 632520-71/13)

\section{Drnholec (Břeclav district) 'Roviny’ (Fig. 3: 7)}

Conical belt pendant with traces of heat damage. Part of the ring eyelet is broken off. The upper globular part of an oval cross-section is separated from the eyelet by a small rib; the semi-globular lower end is well pronounced with sharp edges.

Lit.: Komoróczy et al. 2019b, Fig. 16: 20

Preserved length: $25.6 \mathrm{~mm}$, diameter of upper globular part: $10.5 \times 9.8 \mathrm{~mm}$, cross-section of lower end: $6.8 \mathrm{~mm}$, weight: $6.34 \mathrm{~g}$ Material (XRF surface measurement, \%): $\mathrm{Fe}$ 1.28; Cu 47.61; Sn 17.71; Pb 32.37; Au 0.13; Bi 0.9

Finder: Martin Wollmuth

Held at: Institute of Archaeology of the Czech Academy of Sciences, Brno (inv. no. 632520-25/14)

\section{Drnholec (Břeclav district) 'Roviny' (Fig. 3: 8)}

Conical belt pendant. The upper spherical part of the pendant is connected to the eyelet by a rib. The bar-shaped lower part, narrowed in the middle, is followed by a disc-shaped terminal, the bottom of which features a whirling trefoil motif. A slightly opened link from a bronze chainlet is preserved in the shaft eyelet. Overall length: $25.6 \mathrm{~mm}$, greatest diameter: $9.3 \mathrm{~mm}$, diameter of chainlet link: $6.8 \mathrm{~mm}$, link cross-section $0.9 \times 2 \mathrm{~mm}$, weight: $4.77 \mathrm{~g}$ Material (XRF surface measurement, \%): Cu 65.29; Sn 6.84; $\mathrm{Pb} 27.87$

Finder: Martin Wollmuth

Held at: Institute of Archaeology of the Czech Academy of Sciences, Brno (inv. no. 632520-26/14)

\section{Drnholec (Břeclav district) 'Roviny' (Fig. 3: 9)}

Ring of an oval cross-section, thinned by wear at two opposing spots. Outer diameter: 20.8-21.2 mm, inner diameter: 14.3-16.9 mm, cross-section: 2-3.4 mm, weight: $2.78 \mathrm{~g}$

Material (XRF surface measurement, \%): Fe 0.77; Cu 24.88; Sn 25.04; $\mathrm{Pb} 49.31$

Finder: František Kosour

Held at: Institute of Archaeology of the Czech Academy of Sciences, Brno (inv. no. 632520-54/13)

\section{Drnholec (Břeclav district) 'Roviny' (Fig. 3: 10)}

Ring of a biconvex cross-section, apparently damaged by heat. Outer diameter: $23 \mathrm{~mm}$, maximum inner diameter: $15.4 \mathrm{~mm}$, cross-section: $2.5-3.7 \mathrm{~mm}$, weight: $2.88 \mathrm{~g}$

Material (XRF surface measurement, \%): Fe 0.65; Cu 53.11; Zn 1.68; Sn 17.74; Pb 26.81

Finder: František Kosour

Held at: Institute of Archaeology of the Czech Academy of Sciences, Brno (inv. no. 632520-55/13) 


\section{Horní Věstonice (Břeclav district) 'Pod Transformátorem'} (Fig. 6: 17)

Celts, Pannonia, AE Tetradrachm, Kapos type, second half of the $1^{\text {st }}$ century BC.

Obverse: Head of Zeus in pearl roundel facing right

Reverse: Horse facing left, stylised rider, perhaps female (highlighted bust), arch above horse's head, dots at the ends

Lit.: Pink 1974, no. 484; Torbágyi 1998, 8

$8.97 \mathrm{~g}, 24.35-21.4 \mathrm{~mm}$

Material (XRF surface measurement, \%): Fe 0.87; Cu 53.48; Sn 13.42; Pb 11.65; Ag 19.96; Sb 0.22

Finder: Libor Štoudek

Held at: Institute of Archaeology of the Czech Academy of Sciences, Brno (inv. no. 644579-1/14)

27. Hrušky (Břeclav district) 'Tvrdonické podsedky' (Fig. 6: 2) Boii Celts, Ag obol, Roseldorf/Němčice type, first half of the $2^{\text {nd }}$ century BC.

Obverse: Hump over entire surface

Reverse: Horse facing left, above the horse an arch with bosses at the end, bosses in the middle and below the horse

Lit.: Kolníková 2012, 181, variant Bd

$0.74 \mathrm{~g}, 8.95-9.44 \mathrm{~mm}$, preservation level 1

Material (XRF surface measurement, \%): Cu 2.65; Sn 1.64; $\mathrm{Pb}$ 1.09; Ag 90.34; Au 3.96; Bi 0.09

Finder: Zdeněk Omelka

Held at: Institute of Archaeology of the Czech Academy of Sciences, Brno (inv. no. 648701-1/14)

28. Hrušky (Břeclav district) ‘Tvrdonické podsedky’ (Fig. 4: 1) Belt chain link, model with rectangular side plates with three chainlet holes and a central globular element (without flanking ribs or tapering). The link is apparently a semi-finished piece or a failed casting. One middle hole is poorly cast (irregular large hole with a diameter of $5 \mathrm{~mm}$ ), the adjacent hole is filled with metal (or not perforated), excess metal from casting not ground off around the central globular element; a sprue stub is also found on the side of one plate.

Plate dimensions: $17 \times 11.7 \mathrm{~mm}$ and $16.8 \times 10.4 \mathrm{~mm}$, plate thickness: $2.8 \mathrm{~mm}$, hole diameter: $1.8-2.2 \mathrm{~mm}$, cross-section of the central globular element: $10.4 \times 13 \mathrm{~mm}$, weight: $12.89 \mathrm{~g}$

Material (XRF surface measurement, \%): Fe 0.7; Cu 30.8; Sn 34.41; Pb 33.43; Sb 0.3; Ti 0.59; Bi 0.18; Zr 0.03; Cr 0.12; V 0.11 Finder: Libor Štoudek

Held at: Institute of Archaeology of the Czech Academy of Sciences, Brno (inv. no. 648701-2/14)

29. Hrušky (Břeclav district) 'Tvrdonické podsedky' (Fig. 4: 2) Fragment of a pendant in the form of a wheel. Half of pendant is broken off, originally perhaps four spokes (two preserved along with a trace of a third).

Outer diameter: $30.2 \mathrm{~mm}$, inner diameter: $5.8 \mathrm{~mm}$, round cross-section of wheel circumference: $4.1 \mathrm{~mm}$, round cross-section of hub: $3.2 \mathrm{~mm}$, weight: $5.96 \mathrm{~g}$

Material (XRF surface measurement, \%): Si 1.9; P 2.33; Fe 0.16; $\mathrm{Cu}$ 47.52; Zn 0.14; Sn 23.33; Pb 24.21; Ni 0.07; Sb 0.25; Bi 0.07; Zr 0.02

Finder: Zdeněk Omelka

Held at: Institute of Archaeology of the Czech Academy of Sciences, Brno (inv. no. 648701-8/14)
30. Hrušky (Břeclav district) 'Turdonické podsedky’ (Fig. 4: 3) Ring with a roughly round cross-section, worn thin on one side as a result of use.

Outer diameter: $16 \mathrm{~mm}$, inner diameter: $10.6 \mathrm{~mm}$, cross-section of bar: $3.5 \mathrm{~mm}$ (2.2 $\mathrm{mm}$ at thinner section), weight: $2.29 \mathrm{~g}$

Material (XRF surface measurement, \%): Cu 37.14; Sn 34.29; Pb 28.57 Finder: Petr Spálovský

Held at: Institute of Archaeology of the Czech Academy of Sciences, Brno (inv. no. 648701-1/15)

\section{Hrušky (Břeclav district) 'Tvrdonické podsedky' (Fig. 6: 3)} Boii Celts, Ag obol, Roseldorf/Němčice type, first half of the $2^{\text {nd }}$ century BC.

Obverse: Hump over entire surface

Reverse: Horse facing right, beneath the horse a lyre-shaped mark, full ring in the middle, symbol above horse is illegible Lit.: Kolníková 2012, 179, variant Ac

$0.72 \mathrm{~g}, 8.59-8.86 \mathrm{~mm}$, thickness $2.15 \mathrm{~mm}$, preservation level 2 Material (XRF surface measurement, \%): $\mathrm{Cu}$ 2.06; Pb 0.35; Ag 96.28; Ni 0.18; Au 0.7; Hg 0.44

Finder: Lukáš Kotásek

Held at: Institute of Archaeology of the Czech Academy of Sciences, Brno (inv. no. 648701-2/16)

32. Hrušky (Břeclav district) 'Tvrdonické podsedky' (Fig. 6: 4) Boii Celts, Ag obol, Roseldorf/Němčice type, first half of the $2^{\text {nd }}$ century BC.

Obverse: Hump over entire surface

Reverse: Horse facing left, incomplete arch below, full ring in the middle, illegible mark above the horse

Lit.: Kolníková 2012, 181, variant Bb2

$0.74 \mathrm{~g}, 7.87-8.42 \mathrm{~mm}$, thickness $2.14 \mathrm{~mm}$, preservation level 3

Material (XRF surface measurement, \%): $\mathrm{Fe} 0.25$; $\mathrm{Cu}$ 5.22; Sn 3.75; Pb 1.8; Ag 88.1; Au 0.31; Hg 0.56

Finder: Lukáš Kotásek

Held at: Institute of Archaeology of the Czech Academy of Sciences, Brno (inv. no. 648701-3/16)

33. Hrušky (Břeclav district) 'Tvrdonické podsedky' (Fig. 6: 5) Boii Celts, Ag obol, Roseldorf/Němčice type, first half of the $2^{\text {nd }}$ century BC.

Obverse: Smooth, unstruck, slightly convex

Reverse: Horse facing right, full ring with bar above horse, an illegible lyre-shaped symbol below

Lit.: Kolníková 2012, 179, variant Ac

$0.88 \mathrm{~g}$, 9.63-9.65 mm, thickness $2.05 \mathrm{~mm}$, preservation level 3

Material (XRF surface measurement, \%): $\mathrm{Fe}$ 0.2; Cu 3.24; Sn 0.86; Pb 0.86; Ag 93.91; Au 0.69; Hg 0.23

Finder: Lukáš Kotásek

Held at: Institute of Archaeology of the Czech Academy of Sciences, Brno (inv. no. 648701-4/16)

34. Hrušky (Břeclav district) 'Tvrdonické podsedky' (Fig. 6: 6) Boii Celts, Ag obol, Roseldorf/Němčice type, first half of the $2^{\text {nd }}$ century BC.

Obverse: Smooth, unstruck, slightly convex

Reverse: Horse galloping to the right, bar above horse, lyreshaped symbol below

Lit.: Kolníková 2012, 179, variant Ac

$0.98 \mathrm{~g}, 9.31-9.47 \mathrm{~mm}$, preservation level 2 
New metal and glass finds from the Late Iron Age in South Moravia (CZ). The contribution of citizen science to knowledge... Goláňová, P., Komoróczy, B., Kmošek, M., Kolníková, E., Vlach, M., Zelíková, M. • Přehled výzkumů 61/2, 2020 • 9-41
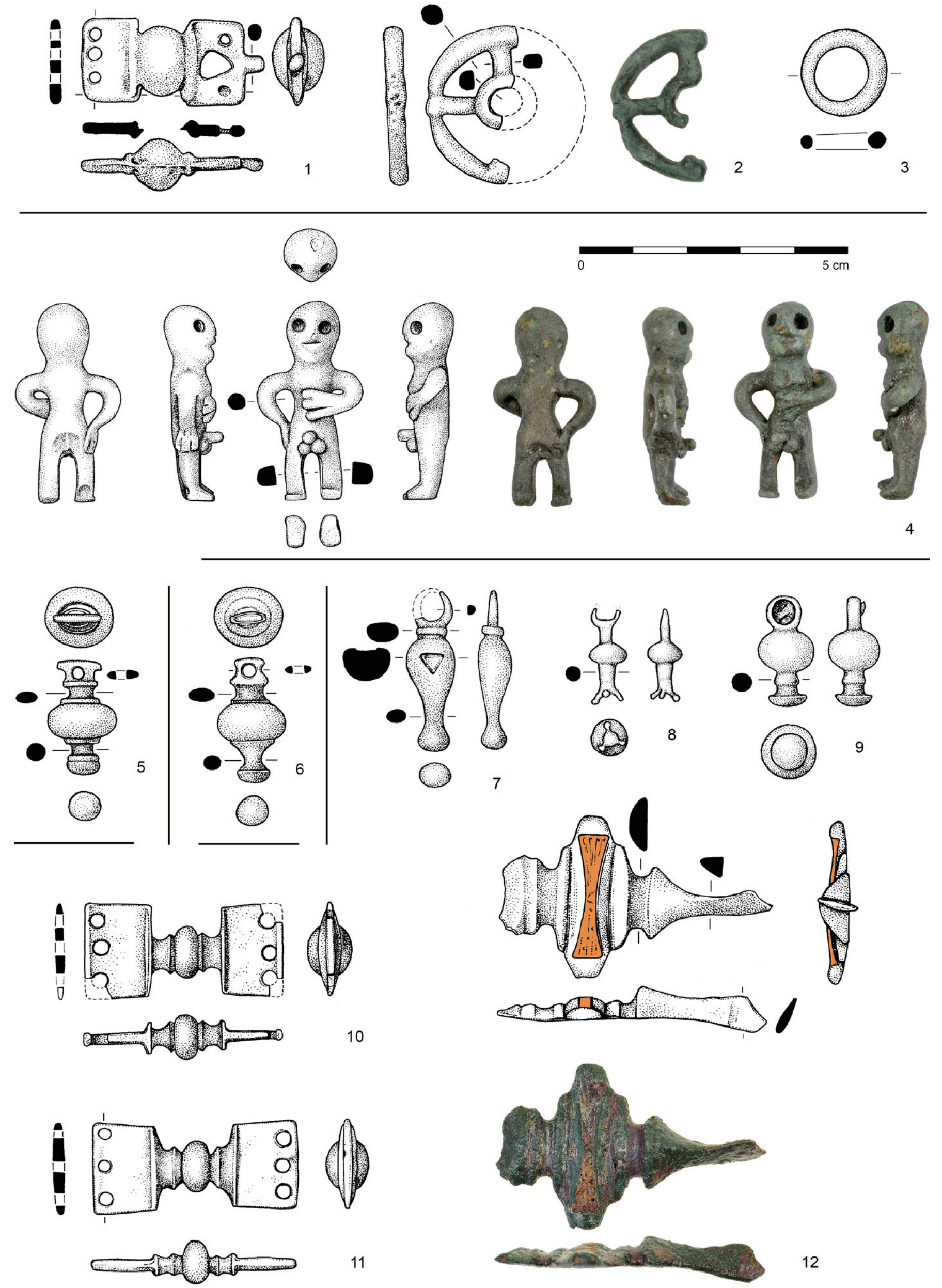
Material (XRF surface measurement, \%): Fe 0.1; $\mathrm{Cu} 2.18 ; \mathrm{Pb} 0.31$; Ag 96.32; Ni 0.16; Au 0.75; Hg 0.17

Finder: Zdeněk Omelka

Held at: Institute of Archaeology of the Czech Academy of Sciences, Brno (inv. no. 648701-7/16)

\section{Hrušky (Břeclav) 'Tvrdonické podsedky' (Fig. 6: 8)}

Boii Celts, Ag obol, Roseldorf/Němčice type, first half of the $2^{\text {nd }}$ century BC.

Obverse: Smooth, unstruck, wide hump

Reverse: Horse galloping to the left, bar and full circle above horse, full circle below

Lit.: Kolníková 2012, 181, variant Bd

$0.73 \mathrm{~g}, 8.96-9.63 \mathrm{~mm}$, preservation level 1

Material (XRF surface measurement, \%): Fe 0.78; Cu 3.56; Sn 0.91; $\mathrm{Pb} 0.65$; Ag 93.17; Ni 0.17; Au 0.77

Finder: Zdeněk Omelka

Held at: Institute of Archaeology of the Czech Academy of Sciences, Brno (inv. no. 648701-8/16)

36. Hrušky (Břeclav district) 'Tvrdonické podsedky' (Fig. 6: 7) Boii Celts, Ag obol, Roseldorf/Němčice type, first half of the $2^{\text {nd }}$ century BC.

Obverse: Smooth, unstruck, slightly convex

Reverse: Horse facing right, indiscernible attributes

Lit.: Kolníková 2012

$0.69 \mathrm{~g}, 8.89-9.66 \mathrm{~mm}$, thickness $1.54 \mathrm{~mm}$, preservation level 4

Material (XRF surface measurement, \%): Fe 0.78; Cu 1.04;

$\mathrm{Pb}$ 0.49; Ag 95.16; Ni 0.16; Au 0.52; Hg 1.80; Bi 0.05

Finder: Lukáš Kotásek

Held at: Institute of Archaeology of the Czech Academy of Sciences, Brno (inv. no. 648701-1/17)

37. Josefov (Hodonín district) 'Pod Rozhranskem’ (Fig. 6: 9) Boii Celts, Au 1/24 stater, first half of the $2^{\text {nd }}$ century BC.

Obverse: Irregular hump, indistinct head

Reverse: Figure of Athena Alkidemos type warrior

Lit.: Paulsen 1933, 141

$0.34 \mathrm{~g}, 6.01-6.04 \mathrm{~mm}$, thickness $1.14 \mathrm{~mm}$, preservation level 1

Material (XRF surface measurement, \%): $\mathrm{Fe} 0.57$; $\mathrm{Cu} 0.13$; Ag 1.27;

Au 98.03

Finder: Lukáš Kotásek

Held at: Institute of Archaeology of the Czech Academy of Sciences, Brno (inv. no. 661490-1/17)

38. Josefov (Hodonín district) ‘Pod Rozhranskem' (Fig. 6: 10) Boii Celts, Au 1/8 stater, first half of the $2^{\text {nd }}$ century BC.

Obverse: Irregular hump, indistinct head

Reverse: Figure of Athena Alkidemos type warrior

Lit.: Paulsen 1933, 108

$0.94 \mathrm{~g}, 9.06-9.66 \mathrm{~mm}$, thickness $1.65 \mathrm{~mm}$, preservation level 3

Material (XRF surface measurement, \%): Fe 0.22; Cu 0.52; Ag 2.49; Ni 0.09; Au 96.68

Finder: Lukáš Kotásek

Held at: Institute of Archaeology of the Czech Academy of Sciences, Brno (inv. no. 661490-2/17)
39. Ladná (Břeclav district) 'Padělky' (Fig. 4: 4)

Anthropomorphic figurine of a standing human with his hands resting on his chest and hip.

Height: $36.7 \mathrm{~mm}$, greatest width: $10 \mathrm{~mm}$, weight: $15.18 \mathrm{~g}$

Material (XRF surface measurement, \%): Fe 0.67; Cu 47.33; Zn 0.03; Sn 21.09; Pb 29.04; Ag 0.5; Ni 0.06; Sb 0.84; Ti 0.24; Bi 0.17; Zr 0.02

Finder: Albert Mihalovič

Held at: Institute of Archaeology of the Czech Academy of Sciences, Brno (inv. no. 678872-1/16)

\section{Ladná (Břeclav district) 'Padělky' (Fig. 4: 5)}

Conical belt pendant. Rectangular plate-like eyelet lined by two ribs, the upper of which is significantly longer. The chainlet hole is round and the eyelet is separated from the body of the pendant by a thin neck. The actual body of the pendant is a slightly flattened sphere with an oval cross-section, with two fine ribs on the sides. The lower conical part ends with a button in the shape of a flattened sphere, flanked by a rib.

Length: $21.8 \mathrm{~mm}$, dimensions of upper part: $8.6 \times 4.9 \mathrm{~mm}$, diameter of opening: $1.9 \mathrm{~mm}$, body cross-section: $12.8 \times 12 \mathrm{~mm}$, cross-section of lower part: $6.2 \mathrm{~mm}$, weight: $7.67 \mathrm{~g}$

Material (XRF surface measurement, \%): $\mathrm{Fe} 0.37 ; \mathrm{Cu} 35.24$; Zn 0.16; Sn 17.35; Pb 45.58; Ni 0.1; Sb 0.37; Ti 0.28; Bi 0.31; Zr 0.04 Finder: Albert Mihalovič

Held at: Institute of Archaeology of the Czech Academy of Sciences, Brno (inv. no. 678872-2/16)

\section{Lanžhot (Břeclav district) 'Horní Štěpnice' (Fig. 4: 6)}

Conical belt pendant. The rectangular plate-like eyelet with a round chainlet hole is separated from the body of the pendant by a thin neck. The actual body of the pendant is a slightly flattened sphere, with a rib in the upper part and an offset in the lower part. The lower conical part ends with a hemispherical button.

Length of pendant: $22.8 \mathrm{~mm}$, rib dimensions: $7.2 \times 4.3 \mathrm{~mm}$, diameter of opening: $2.2 \mathrm{~mm}$, body cross-section: $12.9 \times 11.6 \mathrm{~mm}$, button cross-section: $6.2 \times 5.8 \mathrm{~mm}$, weight: $7.37 \mathrm{~g}$

Material (XRF surface measurement, \%): Fe 1.76; Cu 26.68; Zn 0.67; Sn 24.2; Pb 45.38; Sb 0.38; Ti 0.23; Bi 0.7; Zr 0.04

Finder: Lukáš Kotásek

Held at: Institute of Archaeology of the Czech Academy of Sciences, Brno (inv. no. 679119-1/17)

\section{Lanžhot (Břeclav district) 'Padělky' (Fig. 6: 11)}

Boii Celts, Ag obol, Roseldorf/Němčice type, first half of the $2^{\text {nd }}$ century BC.

Obverse: Hump over entire surface, surface disturbed

Reverse: Horse facing left, full circle below, arch above; from the outer side, a small full circle in the middle

Lit.: Kolníková 2012, 181, variant Bd

$0.65 \mathrm{~g}, 8.92-9.17 \mathrm{~mm}$, thickness $2.10 \mathrm{~mm}$, preservation level 3

Material (XRF surface measurement, \%): Fe 0.39; Cu 2.69; Sn 4.57; $\mathrm{Pb}$ 1.2; Ag 89.5; Au 0.7; Bi 0.1

Finder: Zdeněk Omelka

Held at: Institute of Archaeology of the Czech Academy of Sciences, Brno (inv. no. 679119-2/16) 
New metal and glass finds from the Late Iron Age in South Moravia (CZ). The contribution of citizen science to knowledge... Goláňová, P., Komoróczy, B., Kmošek, M., Kolníková, E., Vlach, M., Zelíková, M. • Přehled výzkumů 61/2, 2020 • 9-41
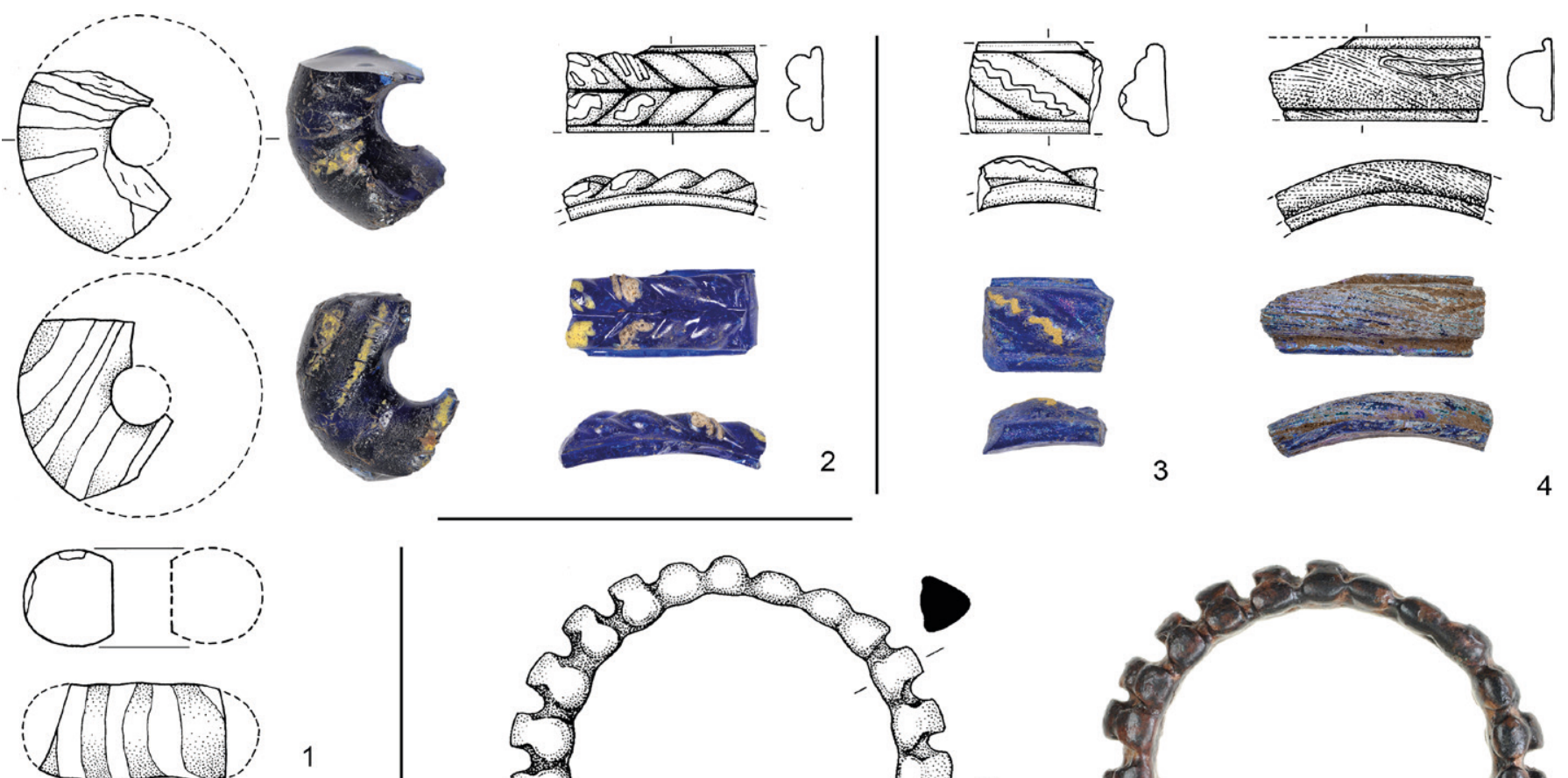

क्रा:

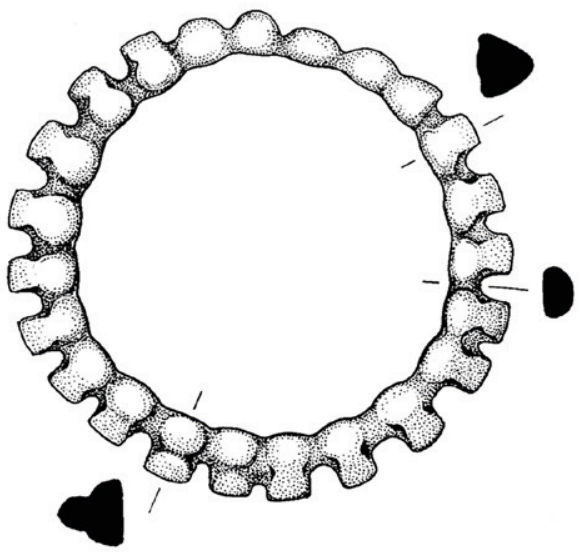

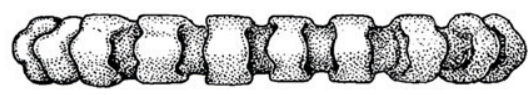

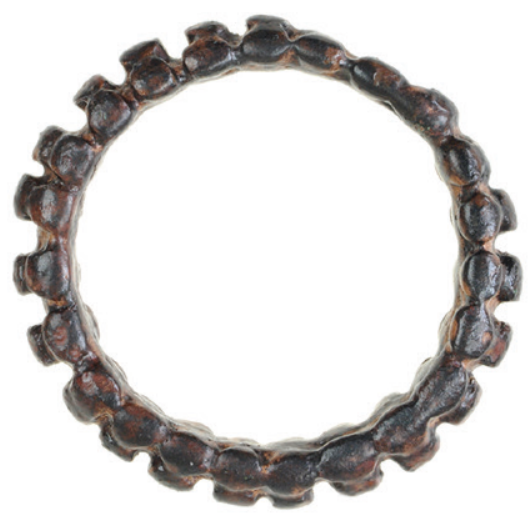

约 6
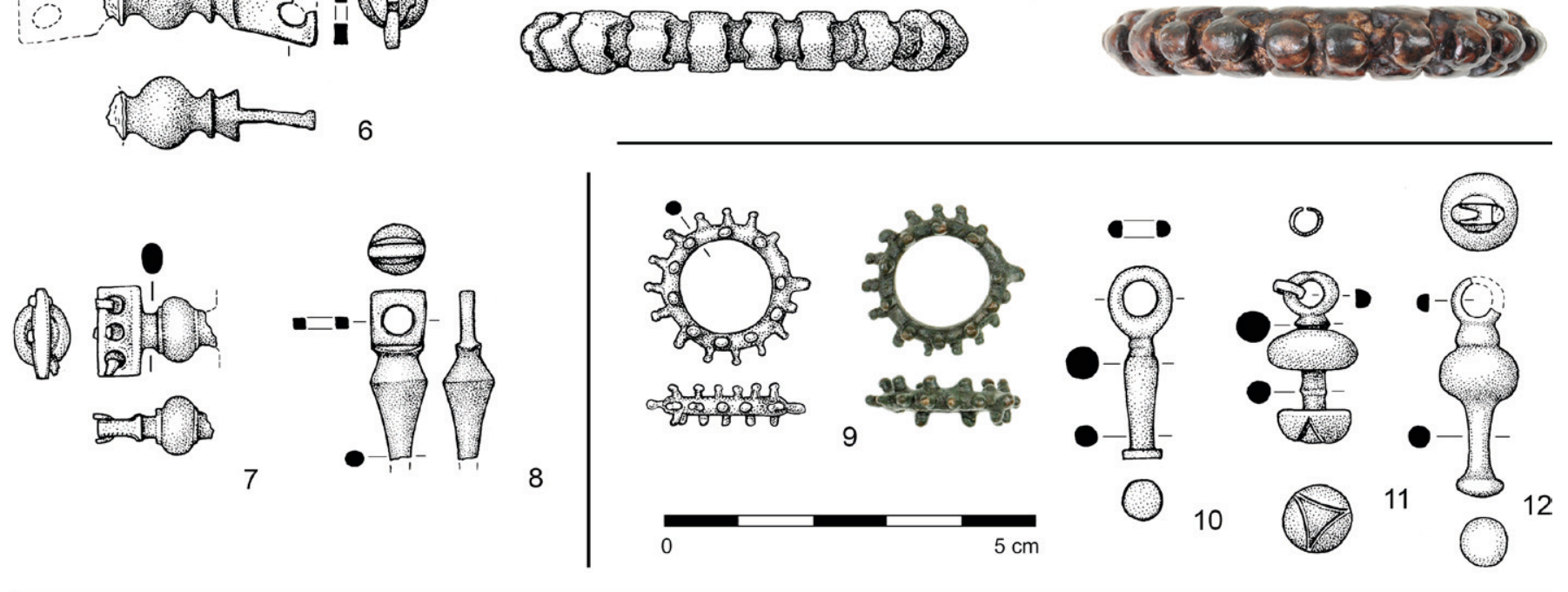

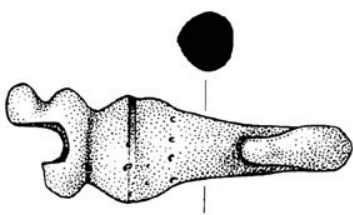

$\mathrm{C}_{1}$

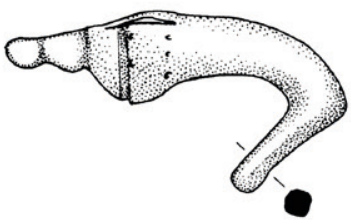

13

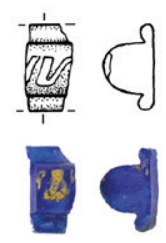

14
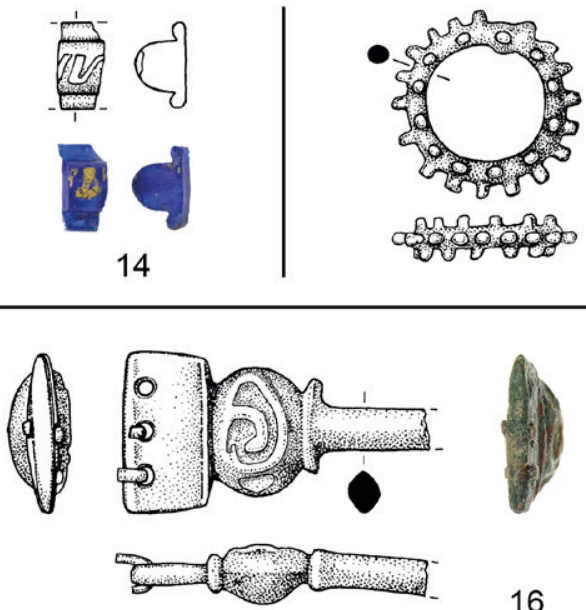
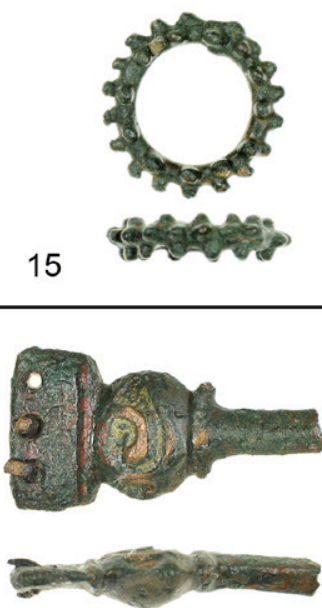
43. Mikulov (Břeclav district) 'Liščí hony’ (Fig. 6: 18)

Celts, Balkans, Philip II (359-336), AE imitation tetradrachm. Obverse: Bearded head of Zeus facing right

Reverse: Illegible

$1041 \mathrm{~g}, 19.62-19.83 \mathrm{~mm}$, thickness $3.98 \mathrm{~mm}$, preservation level 4 Material (XRF surface measurement, \%): Fe 0.3; Cu 0.22; Sn 9.74; $\mathrm{Pb}$ 88.37; Sb 0.4; Bi 0.4; Cr 0.43; V 0.13

Finder: Libor Štoudek

Held at: Institute of Archaeology of the Czech Academy of Sciences, Brno (inv. no. 694193-11/14)

\section{Mikulov (Břeclav district) 'Na Mikulovsku’ (Fig. 5: 2)}

Fragment of a cobalt blue glass bracelet with four ribs and yellow and white wavy lines. The middle two ribs formed with counter-grooves: two 'beads' decorated by white, two adjacent 'beads' by yellow wavy lines, the rest of the preserved part of the bracelet is undecorated. The ribs on the sides are very thin and low. Preserved length: $25 \mathrm{~mm}$, width: $11.7 \mathrm{~mm}$, maximum height: $5.2 \mathrm{~mm}$, diameter: c. $84 \mathrm{~mm}$, weight: $2.45 \mathrm{~g}$

Finder: Robin Pinker

Held at: Institute of Archaeology of the Czech Academy of Sciences, Brno (inv. no. 694193-24/16)

\section{Mikulov (Břeclav district) 'Na Mikulovsku' (Fig. 5: 1)}

Fragment of cobalt blue glass ring bead with yellow radial lines. One fracture is fresh. The core is solid homogeneous glass.

Outer diameter: c. $32 \mathrm{~mm}$, inner diameter: $8 \mathrm{~mm}$, cross-section: $12 \mathrm{~mm}$, height: $13 \mathrm{~mm}$, weight: $7.2 \mathrm{~g}$

Finder: Robin Pinker

Held at: Institute of Archaeology of the Czech Academy of Sciences, Brno (inv. no. 694193-23/16)

\section{Mikulov (Břeclav district) 'Nad Valtickou silnicí' (Fig. 5: 4)}

Fragment of a cobalt blue glass bracelet with a heavily corroded surface (original decoration suggested by a negative line on the corroded surface of the glass). Three ribs - the midrib is high, the side ribs very low and thin.

Preserved length: $30.4 \mathrm{~mm}$, width: $11.3 \mathrm{~mm}$, maximum height: $5.8 \mathrm{~mm}$, diameter: c. $72 \mathrm{~mm}$, weight: $2.63 \mathrm{~g}$

Finder: Václav Holouš

Held at: Institute of Archaeology of the Czech Academy of Sciences, Brno (inv. no. 694193-21/16)

47. Mikulov (Břeclav district) 'Nad Valtickou silnicí’ (Fig. 5: 3) Fragment of a cobalt blue glass bracelet with three ribs and a yellow wavy line, preserved on the midrib with diagonal grooves. The side ribs are low and thin.

Preserved length: $17.4 \mathrm{~mm}$, width: $12.8 \mathrm{~mm}$, maximum height: $6.8 \mathrm{~mm}$, weight: $2.01 \mathrm{~g}$

Finder: Libor Štoudek

Held at: Institute of Archaeology of the Czech Academy of Sciences, Brno (inv. no. 694193-20/16)

48. Mikulov (Břeclav district) 'Nad Valtickou silnicí' (Fig. 5: 5) Massive bronze knobbed ring. The ring has three rows of massive knobs that are hammered/melted in such a way that they form
23 complete 'vertebrae' with a triangular cross-section. In one place the knobs on the outer side are heavily ground down nearly all the way down to the ring itself.

Ring diameter: $52.5 \mathrm{~mm}$, maximum outer diameter, including knobs: $58.1 \mathrm{~mm}$, maximum inner diameter: $44 \mathrm{~mm}$, maximum cross-section: $9.1 \times 8.7 \mathrm{~mm}$, length of one 'vertebra' 5-6 mm, cross-section at spot where the knobs are ground down the most: $6.6 \times 4.6 \mathrm{~mm}$, weight: $48.08 \mathrm{~g}$

Material (XRF surface measurement, \%): Fe 0.28; Cu 65.89; Sn 11.28; Pb 21.17; Ag 0.66; Sb 0.22; Ti 0.15; V 0.10

Finder: Zdeněk Omelka

Held at: Institute of Archaeology of the Czech Academy of Sciences, Brno (inv. no. 694193-69/14)

49. Mikulov (Břeclav district) 'Nad Valtickou silnicí' (Fig. 5: 6) Fragment of belt link with a central globular element, two offset ribs and sharply offset side plates that expand in trapezoidal fashion, originally with two chainlet holes. Only the central part and the fragment of one side plate have been preserved.

Plate dimensions: c. $10.5 \times 10.5 \mathrm{~mm}$ (in the narrower part), thickness: $2.2 \mathrm{~mm}$, chainlet hole diameter: c. $3.2 \mathrm{~mm}$, cross-section of central globular element: $11.3 \times 10.1 \mathrm{~mm}$, weight: $8.8 \mathrm{~g}$

Material (XRF surface measurement, \%): Fe 0.17; Cu 58.57; Sn 16.32; Pb 24.89; Ni 0.05

Finder: Petr Spálovský

Held at: Institute of Archaeology of the Czech Academy of Sciences, Brno (inv. no. 694193-41/15)

50. Mikulov (Břeclav district) 'Nad Valtickou silnicí' (Fig. 5: 7) Fragment of a belt link with a central globular element flanked by ribs on each side followed by bar-like tapering (neck), and with rectangular side plates with three chainlet holes. Only one plate with fragments of wire (halves of connecting chainlet links) in all three holes has been preserved.

Cross-section central globular element: $9 \times 8 \mathrm{~mm}$, plate dimension: $12.9 \times 5.7 \mathrm{~mm}$, plate thickness: $2 \mathrm{~mm}$ (in middle), cross-section of flat wires: $1.7 \times 1.2 \mathrm{~mm}$, chainlet hole diameter: c. $4.4 \mathrm{~mm}$, weight: $3.77 \mathrm{~g}$

Material (XRF surface measurement, \%): Si 3.06; P 0.47; Cu 69.64; Sn 10.02; Pb 15.88; Ag 0.27; Ni 0.11; Sb 0.18; Bi 0.38

Finder: Petr Spálovský

Held at: Institute of Archaeology of the Czech Academy of Sciences, Brno (inv. no. 694193-45/15)

51. Mikulov (Břeclav district) 'Nad Valtickou silnicí' (Fig. 5: 8) Part of a strongly profiled pendant, the end part of which is broken off. The eyelet is a round opening in a roughly square frame that is separated from the conical part by a rib.

Preserved length: $23.3 \mathrm{~mm}$, dimensions of square eyelet: $9 \times 8.4 \mathrm{~mm}$, diameter of conical part: $8 \mathrm{~mm}$, weight: $3.65 \mathrm{~g}$

Material (XRF surface measurement, \%): $\mathrm{Fe}$ 0.47; $\mathrm{Cu}$ 40.6; Sn 11.76; Pb 46.16; Ag 0.26; Ni 0.08; Sb 0.29; Bi 0.17; Zr 0.03, Pd 0.03 Finder: Libor Štoudek

Held at: Institute of Archaeology of the Czech Academy of Sciences, Brno (inv. no. 694193-58/15)

Fig. 5. La Tène finds from the Břeclav region (1-4, 14 glass; 5-13, 15-16 bronze).

1-2 Mikulov - Na Mikulovsku; 3-8 Mikulov - Nad Valtickou silnicí; 9-12 Mikulov - U Aleje; 13 Velké Bílovice - Od Čejkovska; 14 Mikulov - U Vodárny; 15 Sedlec - Za Čelovským; 16 Zaječí - U Obalovny. Photo by P. Růžičková, M. Zelíková; drawing by S. Plchová.

Obr. 5. Laténské nálezy z Břeclavska (1-4, 14 sklo; 5-13, 15-16 bronz).

1-2 Mikulov - Na Mikulovsku; 3-8 Mikulov - Nad Valtickou silnicí; 9-12 Mikulov - U Aleje; 13 Velké Bílovice - Od Čejkovska; 14 Mikulov - U Vodárny; 15 Sedlec - Za Čelovským; 16 Zaječí - U Obalovny. Foto P. Růžičková, M. Zelíková; kresba S. Plchová. 


\section{Mikulov (Břeclav district) 'U Aleje’ (Fig. 5: 9)}

Knobbed ring. Bar-like knobs in three rows $(10+15+5$, partially broken off on one side). One of the knobs on the outer perimeter is probably a remnant of casting.

Maximum diameter with knobs: $21 \mathrm{~mm}$, inner diameter of ring: $12.4 \mathrm{~mm}$, cross-section of ring: $2.3 \mathrm{~mm}$, weight: $3.18 \mathrm{~g}$

Material (XRF surface measurement, \%): Fe 0.45; Cu 55.51; Sn 15.84; Pb 27.17; Sb 0.16; Ti 0.36; V 0.14

Finder: Václav Holouš

Held at: Institute of Archaeology of the Czech Academy of Sciences, Brno (inv. no. 694193-25/14)

\section{Mikulov (Břeclav district) 'U Aleje' (Fig. 5: 11)}

Pendant from belt chain, with one link of the connecting chainlet preserved in the shaft eyelet. The shaft eyelet of an oval shape is connected to a flattened sphere by a rib. The lower part of the pendant is composed of a bar-like part with a nearly indiscernible knot and a hemispherical termination with incised decoration (viewed from below) in the shape of a triangle.

Length: $23.8 \mathrm{~mm}$, diameter of upper globular element: $12.2 \mathrm{~mm}$, diameter of lower hemisphere: $10 \mathrm{~mm}$, cross-section of connecting bar: $3.5 \mathrm{~mm}$, outer dimensions of shaft eyelet: $8 \times 6 \mathrm{~mm}$, inner diameter of shaft eyelet: $3 \mathrm{~mm}$, diameter of chainlet link: $4.8 \mathrm{~mm}$, link strip width: $1.6 \mathrm{~mm}$, weight: $8.79 \mathrm{~g}$

Material (XRF surface measurement, \%): Fe 0.13; Cu 66.67; Sn 13.05; $\mathrm{Pb}$ 19.21; Sb 0.18; Ti 0.35; Bi 0.15; V 0.12

Finder: Václav Holouš

Held at: Institute of Archaeology of the Czech Academy of Sciences, Brno (inv. no. 694193-32/14)

\section{Mikulov (Břeclav district) 'U Aleje' (Fig. 5: 12)}

Conical belt pendant with part of the eyelet broken off. Eyelet is separated from the main spherical part by an offset rib. The lower part of the pendant is an elongated biconical bar that ends with a disc.

Preserved length: $29.6 \mathrm{~mm}$, diameter of spherical part: $10.6 \mathrm{~mm}$, disc diameter: $6.6 \mathrm{~mm}$, weight: $7.29 \mathrm{~g}$

Material (XRF surface measurement, \%): Fe 0.1; Cu 74.31; Sn 5.14; $\mathrm{Pb}$ 19.96; Ni 0.05; Sb 0.04; Ti 0.11; Bi 0.23; Co 0.09

Finder: Václav Holouš

Held at: Institute of Archaeology of the Czech Academy of Sciences, Brno (inv. no. 694193-33/14)

\section{Mikulov (Břeclav district) 'U Aleje' (Fig. 5: 10)}

Bar-shaped belt pendant (?) with a large round eyelet and a discoid terminal that is flat on the bottom. A hint of a rib between the eyelet with a plano-convex cross-section and the body of the pendant.

Length: $26.6 \mathrm{~mm}$, maximum diameter of bar section: $4.9 \mathrm{~mm}$, disc diameter: $5.4 \mathrm{~mm}$, outer diameter of eyelet: $8.9 \mathrm{~mm}$, inner diameter of eyelet: $4.7 \mathrm{~mm}$, weight: $2.94 \mathrm{~g}$

Material (XRF surface measurement, \%): Fe 0.26; Cu 59.91; Sn 17.35; Pb 21.83; Sb 0.11; Bi 0.15; Co 0.16

Finder: Václav Holouš

Held at: Institute of Archaeology of the Czech Academy of Sciences, Brno (inv. no. 694193-34/14)

\section{Mikulov (Břeclav district) 'U Vodárny’ (Fig. 5: 14)}

Fragment of a cobalt blue glass bracelet with a highly arched yellow wavy line. High middle rib, two low ribs on the sides.

Preserved length: $5.4 \mathrm{~mm}$, width: $10.1 \mathrm{~mm}$, weight: $0.44 \mathrm{~g}$ Finder: Robin Pinker

Held at: Institute of Archaeology of the Czech Academy of Sciences, Brno (inv. no. 694193-22/16)
57. Mušov (Brno-venkov district) ‘Na Pískách’ (Fig. 4: 10)

Nearly fully preserved belt chain link. Model with rectangular to slightly trapezoidal side plates (three chainlet holes in each) and a central globular element with ribs on each side followed by bar-like tapering. The side plates have distinctive ribs on the side facing the central globular element.

Length: $37.8 \mathrm{~mm}$, cross-section of central rolled metal piece: $10 \times 9.2 \mathrm{~mm}$, maximum plate dimensions: $18.8 \times 12.2 \mathrm{~mm}$, plate thickness: $2 \mathrm{~mm}$, hole diameter: c. $2.7 \mathrm{~mm}$, weight: $10.73 \mathrm{~g}$

Material (XRF surface measurement, \%): $\mathrm{Fe} 0.3$; $\mathrm{Cu}$ 51.92; Sn 9.09; Pb 38.58; Co 0.1

Finder: Martin Wollmuth

Held at: Institute of Archaeology of the Czech Academy of Sciences, Brno (inv. no. 10040/5-39/11)

\section{Mušov (Brno-venkov district) 'Na Pískách' (Fig. 4: 12)}

Fragment (damaged by heat?) of a belt hook with traces of enamel decoration. The belt hook probably originally ended with a flat annular element (broken off) separated from the preserved part by a rib. The middle part composed of a perpendicular elongated oval plate flanked by ribs is decorated with depression in the form of biconcave lens (dimensions $24.6 \times 2-5 \mathrm{~mm}$ ) filled with red enamel. The enamel was evidently originally decorated with hatched triangles. The central part of the belt hook is followed by a triangular projection which, on the horizontal level (with respect to the body of the belt hook) tapers and expands on the vertical plane. The hook is broken off. The back side is flat and expanded at the place of the projecting triangular terminal. Preserved length: $50 \mathrm{~mm}$, original outer diameter of the annular part: c. $30 \mathrm{~mm}$, dimensions of central plate (without side ribs): $30.8 \times 8.8 \mathrm{~mm}$, maximum thickness: $5.8 \mathrm{~mm}$, weight $14.75 \mathrm{~g}$ Material (XRF surface measurement, \%): Fe 0.17; Cu 64.11; Sn 13.82; Pb 21.72; Sb 0.09

Finder: Zdeněk Omelka

Held at: Institute of Archaeology of the Czech Academy of Sciences, Brno (inv. no. 10040/5-54/14)

59. Mušov (Brno-venkov district) 'Na Pískách' (Fig. 4: 11) Fully preserved belt chain link. Model with rectangular to slightly trapezoidal side plates (three chainlet holes in each) and a central globular element with ribs on each side followed by tapering. The chainlet holes in the plates are not completely symmetrically arranged.

Length: $38.6 \mathrm{~mm}$, cross-section of middle rolled metal piece: $9.9 \times 8.3 \mathrm{~mm}$, plate dimensions: $15.2-17.5 \times 12 \mathrm{~mm}$ and $15.3-16.8 \times$ $12.3 \mathrm{~mm}$, thickness of plates in the middle: $2.6 \mathrm{~mm}$, diameter of holes: c. $2.3-2.9 \mathrm{~mm}$, weight: $11.1 \mathrm{~g}$

Material (XRF surface measurement, \%): Si 6.95; Fe 1.07; Cu 20.29; Sn 27.58; $\mathrm{Pb} 44.11$

Finder: Martin Wollmuth

Held at: Institute of Archaeology of the Czech Academy of Sciences, Brno (inv. no. 10040/5-71/11)

\section{Mušov (Brno-venkov district) ‘Na Pískách’ (Fig. 4: 8)}

Small pendant from a belt chain. The eyelet is broken in half, beneath it is a short bar-shaped part expanding in its central part into an irregular spherical element. This sphere is followed by a thicker barshaped part ending with three knobs (only one of which is apparently preserved completely). The knobs have small relief dots on their end. Preserved length: $18.5 \mathrm{~mm}$, cross-section of bar-shaped part: 2.5-3.6 mm, diameter of spherical elements: $7.4 \mathrm{~mm}$, diameter of relief dots: $2.2 \mathrm{~mm}$, weight: $2.02 \mathrm{~g}$

Material (XRF surface measurement, \%): Fe 0.41; Cu 54.47; Sn 13.12; $\mathrm{Pb}$ 31.03; Ni 0.08 

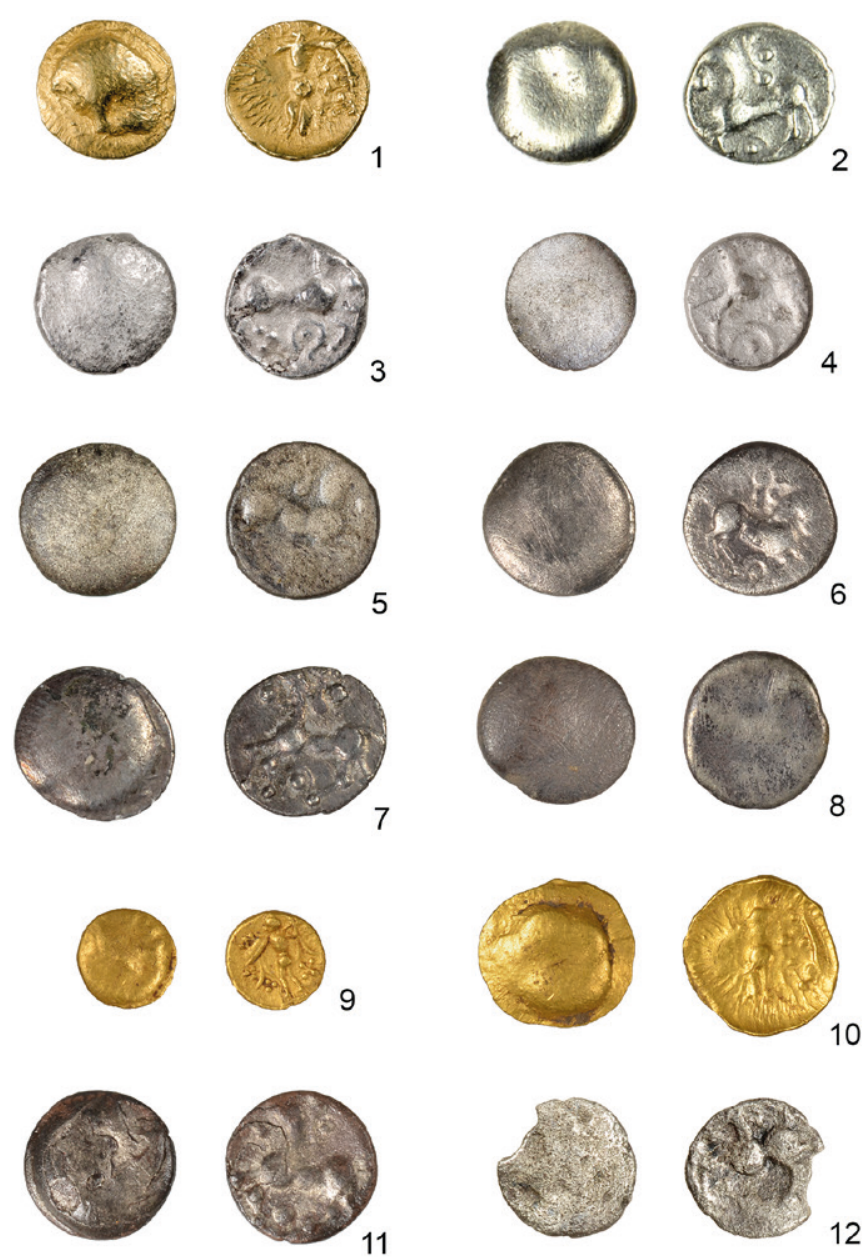

12
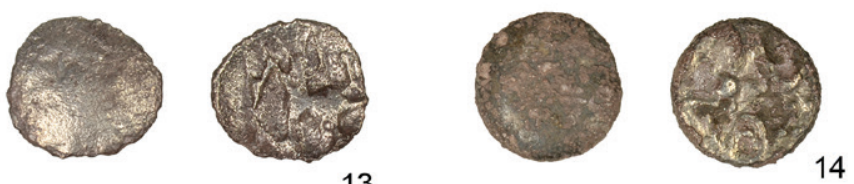

13
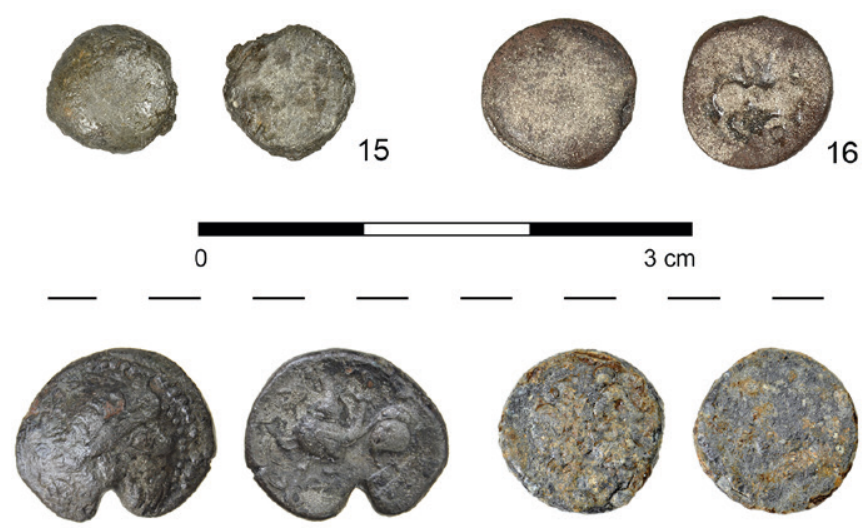

17

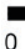

0
Finder: Martin Wollmuth

Held at: Institute of Archaeology of the Czech Academy of Sciences, Brno (inv. no. 10040/5-36/11)

61. Mušov (Brno-venkov) ‘Na Pískách’ (Fig. 4: 9)

Belt pendant. The spherical part is directly connected to the eyelet. The element in the shape of a spherical cap ends with a bar-shaped part with a spherical middle part. The shaft eyelet is partially covered with black organic matter, which also fills the hole in which a fragment of a chainlet link was preserved.

Length: $20.8 \mathrm{~mm}$, outer diameter of eyelet: $6.9 \mathrm{~mm}$, diameter of spherical part: $10 \mathrm{~mm}$, diameter of terminal: $6.6 \mathrm{~mm}$, weight: $5.52 \mathrm{~g}$ Material (XRF surface measurement, \%): Fe 0.25; Cu 46.62; Sn 15.94; Pb 37.2

Finder: Martin Wollmuth

Held at: Institute of Archaeology of the Czech Academy of Sciences, Brno (inv. no. 10040/5-37/11)

62. Mušov (Brno-venkov district) 'Na Pískách' (Fig. 4: 7)

Conical belt pendant. The round eyelet is partially broken off, thinner in the upper part due to wear, separated from the body of the pendant by a rib. The front side of the pendant is irregularly convex, the other slightly flattened. A triangular depression, apparently intended to hold enamel, is located at the widest part of the pendant body on its front side. The pendant ends with a small flattened spherical element.

Preserved length: $30 \mathrm{~mm}$, cross-section of body: $9.3 \times 6.4 \mathrm{~mm}$, cross-section of end spherical element: $6.2 \times 4.8 \mathrm{~mm}$, weight: $5.45 \mathrm{~g}$ Material (XRF surface measurement, \%): $\mathrm{Fe} 0.79 ; \mathrm{Cu} 41.59$; Sn 10.51; Pb 46.99; Mn 0.11

Finder: Martin Wollmuth

Held at: Institute of Archaeology of the Czech Academy of Sciences, Brno (inv. no. 10040/5-38/11)

63. Pasohlávky (Brno-venkov district) 'Drobné př́íěly’ (Fig. 6: 12) Celts, Ag obol, Karlstein type, second half of the $1^{\text {st }}$ century BC. Obverse: Unstruck

Reverse: Horse facing left

Lit.: Paulsen 1933, 622

$0.36 \mathrm{~g}, 7.77-8.52 \mathrm{~mm}$, preservation level 4

Material (XRF surface measurement, \%): Fe 0.27; Cu 2.95; Pb 0.56; Ag 95.31; Au 0.38; Hg 0.44; Bi 0.08

Finder: Petr Spálovský

Held at: Institute of Archaeology of the Czech Academy of Sciences, Brno (inv. no. 718220-2/15)

64. Př́tluky (Břeclav district) 'U Hluboké vody’ (Fig. 6: 13) Celts, Ag obol, Karlstein type, second half of the $1^{\text {st }}$ century BC. Obverse: Indistinct head

Reverse: Horse facing left, faulty strike

$0.37 \mathrm{~g}, 8.61-9.37 \mathrm{~mm}$, thickness $1.35 \mathrm{~mm}$, preservation level 4 Material (XRF surface measurement, \%): Fe 0.17; Cu 2.46; Pb 0.35; Ag 95.58; Ni 0.14; Au 0.55; Hg 0.75

Finder: Zdeněk Omelka

Held at: Institute of Archaeology of the Czech Academy of Sciences, Brno (inv. no. 736333-2/16)

Fig. 6. Coin finds (1, 9-10 gold alloy; 2-8, 11-14, 16-17 silver alloy; 15 tin-lead alloy, 18 lead-tin alloy) - Břeclav district (1-8, 11, 13-18), Hodonín district (9-10) and Brno-venkov district (12). 1 Břeclav - Žleby; 2-8 Hrušky - Tvrdonické podsedky; 9-10 Josefov - Pod Rozhranskem; 11 Lanžhot - Padělky; 12 Pasohlávky - Drobné př́íděly; 13 Př́tlluky - U Hluboké vody; 14 Rakvice - Díly; 15 Rakvice - Rybníčky; 16 Tvrdonice - Pole od Týnecka; 17 Horní Věstonice - Pod Transformátorem; 18 Mikulov - Liščí hony. Photo by P. Růžičková, M. Zelíková.

Obr. 6. Mincovní nálezy (1, 9-10 zlato; 2-8, 11-14, 16-17 stř́bro; 15 slitina cínu, 18 slitina olova) - okr. Břeclav (1-8, 11, 13-18), okr. Hodonín (9-10) a okr. Brno-venkov (12). 1 Břeclav - Žleby; 2-8 Hrušky - Tvrdonické podsedky; 9-10 Josefov - Pod Rozhranskem; 11 Lanžhot - Padělky; 12 Pasohlávky - Drobné příděly; 13 Př́tlluky - U Hluboké vody; 14 Rakvice - Díly; 15 Rakvice - Rybníčky; 16 Tvrdonice - Pole od Týnecka; 17 Horní Věstonice - Pod Transformátorem; 18 Mikulov - Liščí hony. Foto P. Rủžičková, M. Zelíková. 
65. Rakvice (Břeclav district) 'Díly' (Fig. 6: 14)

Boii Celts, Ag obol, Roseldorf/Němčice type, first half of the $2^{\text {nd }}$ century BC.

Obverse: Flat hump

Reverse: Horse facing left, beneath the horse is an arch with a small full ring in the middle, a slight arch above

Lit.: Kolníková 2012, 180, variant B7

$0.76 \mathrm{~g}, 8.91-9.06 \mathrm{~mm}$, thickness $2.31 \mathrm{~mm}$, preservation level 3

Material (XRF surface measurement, \%): $\mathrm{Fe} 4.73$; $\mathrm{Cu}$ 2.04; Sn 0.89; Pb 1.37; Ag 87.62; Ti 1.16; Au 0.93; Bi 0.12; Cr 0.66; V 0.47 Finder: Unknown

Held at: Institute of Archaeology of the Czech Academy of Sciences, Brno (inv. no. 739201-2/16)

\section{Rakvice (Břeclav district) 'Rybníčky' (Fig. 6: 15)}

Boii Celts, AE obol, Roseldorf/Němčice type, first half of the $2^{\text {nd }}$ century BC.

Obverse: Hump

Reverse: Horse facing left, indiscernible attributes

Lit.: Kolníková 2012, 180

$0.68 \mathrm{~g}, 7.83-7.96 \mathrm{~mm}$, thickness $2.60 \mathrm{~mm}$, preservation level 4

Material (XRF surface measurement, \%): Fe 0.34; Cu 0.49; Sn 71.39;

$\mathrm{Pb}$ 26.37; Sb 1.25; Bi 0.15; Zr 0.02

Finder: Zdeněk Omelka

Held at: Institute of Archaeology of the Czech Academy of Sciences, Brno (inv. no. 739201-8/16)

\section{Sedlec (Břeclav) 'Za Čelovským' (Fig. 5: 15)}

Knobbed ring with a round cross-section. Bar-like to spherical knobs in three rows $(12+18+12)$. In one spot the knobs in the middle row are indistinct (merged), and there is also one projection on the inner side of the ring (the place from where the piece was cast?). Maximum diameter with knobs: $21.4 \mathrm{~mm}$, inner diameter of ring: $14.1 \mathrm{~mm}$, cross-section of ring: $2.5 \mathrm{~mm}$, weight: $3.67 \mathrm{~g}$

Material (XRF surface measurement, \%): Fe 0.64; Cu 51.78; Sn 29.93; Pb 16.08; Ag 0.22; Sb 0.31; Ti 0.43; Bi 0.24; Zr 0.02; V 0.1 Finder: Libor Štoudek

Held at: Institute of Archaeology of the Czech Academy of Sciences, Brno (inv. no. 746789-1/14)

68. Tvrdonice (Břeclav district) 'Pole od Týnecka' (Fig. 6: 16) Boii Celts, Ag obol, Roseldorf/Němčice type, first half of the $2^{\text {nd }}$ century BC.

Obverse: Flat Hump over entire surface of coin

Reverse: Horse facing right, with a lyre symbol below and a bar above Lit.: Kolníková 2012, 179, variant Ac

$0.95 \mathrm{~g} 9.21-9.38 \mathrm{~mm}$, thickness $1.99 \mathrm{~mm}$, preservation level 3

Material (XRF surface measurement, \%): Fe 0.24; Cu 2.46; $\mathrm{Pb}$ 0.38; Ag 95.74; Ni 0.12; Au 0.76; Hg 0.23; Bi 0.05

Finder: Libor Štoudek

Held at: Institute of Archaeology of the Czech Academy of Sciences, Brno (inv. no. 772020-1/16)

\section{Velké Bílovice (Břeclav district) 'Od Čejkovska’ (Fig. 5: 13)} Part of a chain belt hook damaged by fire. The preserved end part has a hook in the form of a horse head (with barely discernible ears). This is followed by a hemispherical element with a perpendicular groove that was originally connected to the chain belt with the eyelet, originally oval in shape and with profiled sides. Preserved length: $40.5 \mathrm{~mm}$, cross-section of hemispherical element: $12.7 \times 11.1 \mathrm{~mm}$, hook length: $15.2 \mathrm{~mm}$, weight: $14.44 \mathrm{~g}$ Material (XRF surface measurement, \%): Fe 1.61; Cu 35.89; Zn 0.03; Sn 19.04; Pb 40.22; Ni 0.16; Sb 2.68; Bi 0.24; Zr 0.02 Finder: Jan Jakubčík
Held at: Institute of Archaeology of the Czech Academy of Sciences, Brno (inv. no. 778672-1/17)

\section{Zaječí (Břeclav district) 'U Obalovny’ (Fig. 5: 16)}

Fragment of belt hook from belt chain. Preserved is a rectangular side plate with three chainlet holes, flanked by the flattened globular central part with engraved spiral decoration forming depression (originally for enamel, which has not been preserved). A rib separates the central part from the bar-shaped part with assumed hook, which is broken off. Remnants of chainlet links from flattened wire are preserved in two holes in the side plate. The dorsal part of the belt hook is profiled, and the central part is more convex than the ventral part.

Preserved length: $36.6 \mathrm{~mm}$, cross-section (rhombic) of bar-shaped part: $5.2 \times 4.2 \mathrm{~mm}$, cross-section of central part: $14.8 \times 7.7 \mathrm{~mm}$, diameter of chainlet hole: $2.6 \mathrm{~mm}$, cross-section of preserved wire (link): $1.3 \times 1.9 \mathrm{~mm}$, original chainlet link diameter: c. $5.4 \mathrm{~mm}$, weight: $11.88 \mathrm{~g}$

Material (XRF surface measurement, \%): Fe 0.37; $\mathrm{Cu}$ 39.01; Zn 0.12; Sn 33.8; Pb 25.32; Ag 0.32; Sb 0.34; Bi 0.38; Zr 0.02

Finder: Zdeněk Omelka

Held at: Institute of Archaeology of the Czech Academy of Sciences, Brno (inv. no. 790346-3/14)

\section{Elemental composition analysis of the metal artefacts}

More detailed knowledge of the nature and significance of the presented artefacts is provided by their material examination in terms of elemental composition. All non-ferrous metal artefacts in the studied assemblage (65 specimens) were analysed on the surface using a hand-held portable XRF spectrometer (pXRF - portable X-Ray fluorescence, the results of which are listed in the catalogue for individual finds and summarised in Tab. 2 and 3). With the exception of coin finds, the artefacts (a total of 47 specimens) were subsequently subjected to a more accurate bulk analysis of metal core samples by ED-XRF benchtop spectrometer, the results of which are provided in Tab. 4.

The surface measurements were performed by two analysts (M. Hložek, M. Kmošek) over several years using different devices (Niton X13t 980, Olympus Delta Professional) under various measurement conditions. When interpreting the results of surface measurements with hand-held spectrometers, many factors ${ }^{1}$ influencing the resulting data must be taken into account (Pollard, Bray 2014). Surface measurements capture only the composition of the thin, significantly altered surface layer of the artefact (in detail with other literature in Lutz 1998, 172). The results of surface measurements must be taken at most as semi-quantitative and as such they serve only for a basic illustration of the types of alloys from which the objects were made.

The results of surface measurements of coin finds (Tab. 2) show that silver coins predominate in numbers. In addition to silver, they contain an admixture of gold, copper, lead, and in some cases also tin and trace amounts of nickel and bismuth. The occurrence of gold, lead and bismuth in a silver coin alloy is probably related to their natural occurrence in the original ore. In contrast, copper and tin usually indicate the intentional alloying of silver with copper or possibly tin bronze (Militký 2018b, 412). The possibility of alloying with leaded or leaded tin bronze also cannot be ruled out.

The trio of gold coins from Břeclav - Žleby and Josefov Pod Rozhranskem (Cat. no. 10, 37, 38; Fig. 6: 1, 9-10) contain an admixture of silver and copper and trace amounts of nickel. The only copper alloy coin from Horní Věstonice (Cat. no. 26; Fig. 6: 17) is alloyed with tin, lead and silver and contains an admixture of antimony. 
New metal and glass finds from the Late Iron Age in South Moravia (CZ). The contribution of citizen science to knowledge...

Goláňová, P., Komoróczy, B., Kmošek, M., Kolníková, E., Vlach, M., Zelíková, M. • Přehled výzkumů 61/2, 2020 • 9-41

\begin{tabular}{|c|c|c|c|c|c|c|c|c|c|c|c|c|c|c|c|}
\hline ID & Artefact & $\mathrm{Ag}$ & $\mathrm{Au}$ & $\mathrm{Cu}$ & $\mathrm{Pb}$ & Sn & Sb & $\mathrm{Bi}$ & $\mathrm{Ni}$ & $\mathrm{Fe}$ & $\mathrm{Hg}$ & $\mathrm{Ti}$ & $\mathrm{Zr}$ & $\mathrm{Cr}$ & v \\
\hline 10 & coin & 3.26 & 95.61 & 0.9 & 0 & 0 & 0 & 0 & 0.07 & 0.17 & 0 & 0 & 0 & 0 & 0 \\
\hline 26 & coin & 19.96 & 0 & 53.48 & 11.65 & 13.42 & 0.22 & 0 & 0 & 0.87 & 0 & 0 & 0 & 0 & 0 \\
\hline 27 & coin & 90.34 & 3.96 & 2.65 & 1.09 & 1.64 & 0 & 0.09 & 0 & 0 & 0 & 0 & 0 & 0 & 0 \\
\hline 31 & coin & 96.28 & 0.7 & 2.06 & 0.35 & 0 & 0 & 0 & 0.18 & 0 & 0.44 & 0 & 0 & 0 & 0 \\
\hline 32 & coin & 88.1 & 0.31 & 5.22 & 1.8 & 3.75 & 0 & 0 & 0 & 0.25 & 0.56 & 0 & 0 & 0 & 0 \\
\hline 33 & coin & 93.91 & 0.69 & 3.24 & 0.86 & 0.86 & 0 & 0 & 0 & 0.2 & 0.23 & 0 & 0 & 0 & 0 \\
\hline 34 & coin & 96.32 & 0.75 & 2.18 & 0.31 & 0 & 0 & 0 & 0.16 & 0.1 & 0.17 & 0 & 0 & 0 & 0 \\
\hline 35 & coin & 93.17 & 0.77 & 3.56 & 0.65 & 0.91 & 0 & 0 & 0.17 & 0.78 & 0 & 0 & 0 & 0 & 0 \\
\hline 36 & coin & 95.16 & 0.52 & 1.04 & 0.49 & 0 & 0 & 0.05 & 0.16 & 0.78 & 1.8 & 0 & 0 & 0 & 0 \\
\hline 37 & coin & 1.27 & 98.03 & 0.13 & 0 & 0 & 0 & 0 & 0 & 0.57 & 0 & 0 & 0 & 0 & 0 \\
\hline 38 & coin & 2.49 & 96.68 & 0.52 & 0 & 0 & 0 & 0 & 0.09 & 0.22 & 0 & 0 & 0 & 0 & 0 \\
\hline 42 & coin & 89.50 & 0.7 & 2.69 & 1.2 & 4.57 & 0 & 0.10 & 0 & 0.39 & 0 & 0 & 0 & 0 & 0 \\
\hline 43 & coin & 0 & 0 & 0.22 & 88.37 & 9.74 & 0.4 & 0.40 & 0 & 0.30 & 0 & 0 & 0 & 0.43 & 0.13 \\
\hline 63 & coin & 95.31 & 0.38 & 2.95 & 0.56 & 0 & 0 & 0.08 & 0 & 0.27 & 0.44 & 0 & 0 & 0 & 0 \\
\hline 64 & coin & 95.58 & 0.55 & 2.46 & 0.35 & 0 & 0 & 0 & 0.14 & 0.17 & 0.75 & 0 & 0 & 0 & 0 \\
\hline 65 & coin & 87.62 & 0.93 & 2.04 & 1.37 & 0.89 & 0 & 0.12 & 0 & 4.73 & 0 & 1.16 & 0 & 0.66 & 0.47 \\
\hline 66 & coin & 0 & 0 & 0.49 & 26.37 & 71.39 & 1.25 & 0.15 & 0 & 0.34 & 0 & 0 & 0.02 & 0 & 0 \\
\hline 68 & coin & 95.74 & 0.76 & 2.46 & 0.38 & 0 & 0 & 0.06 & 0.12 & 0.24 & 0.23 & 0 & 0 & 0 & 0 \\
\hline
\end{tabular}

Tab. 2. Results of pXRF surface analysis of coin finds (numbers correspond to individual items in the catalogue part).

Tab. 2. Výsledky pXRF prvkové analýzy povrchu mincovních nálezů (čísla odpovídají jednotlivým položkám v katalogové části).

An unusual material composition was detected in case of two coins made of an alloy of tin and lead (with different ratios of the two metals) with an admixture of copper, antimony and bismuth, without any precious metal content. These are an tetradrachm imitation of Philip II of Macedon from Mikulov - Liščí hony (Cat. no. 43; Fig. 6: 18) with a lead content of nearly $90 \%$ and a tin content of $10 \%$, and a Němčice-Roseldorf type obol from Rakvice Rybníčky (Cat. no. 66; Fig. 6:15), made, in contrast, from more than $70 \%$ tin and $26 \%$ lead. The explanation for this material anomaly has not yet been reliably clarified and, given the limited number of similar analysed coins, there are no parallel finds so far.

On the contrary, the results of surface measurements of noncoin finds show that the artefacts were made exclusively of copper alloys, more precisely leaded tin bronze (Tab. 3). In most cases, traces of silver, antimony, bismuth, zinc, gold, cobalt and nickel were also identified. More accurate data are provided by the results of bulk analysis (Tab. 4); in contrast to surface analysis, they more credibly capture the composition of the original alloy. Microsamples of the metal core were taken from a total of 47 artefacts by drilling with a $1 \mathrm{~mm}$ diameter HSS-TiN drill; the subsequent analysis were performed by an ElvaX Pro benchtop XRF spectrometer. ${ }^{2}$ Even in this case, it is necessary to take into account factors influencing the results of the analysis, which include in particular the inhomogeneity of the material, especially with respect to the heterogeneous distribution of lead in the copper alloy (Chakrabarti, Laughlin 1984).

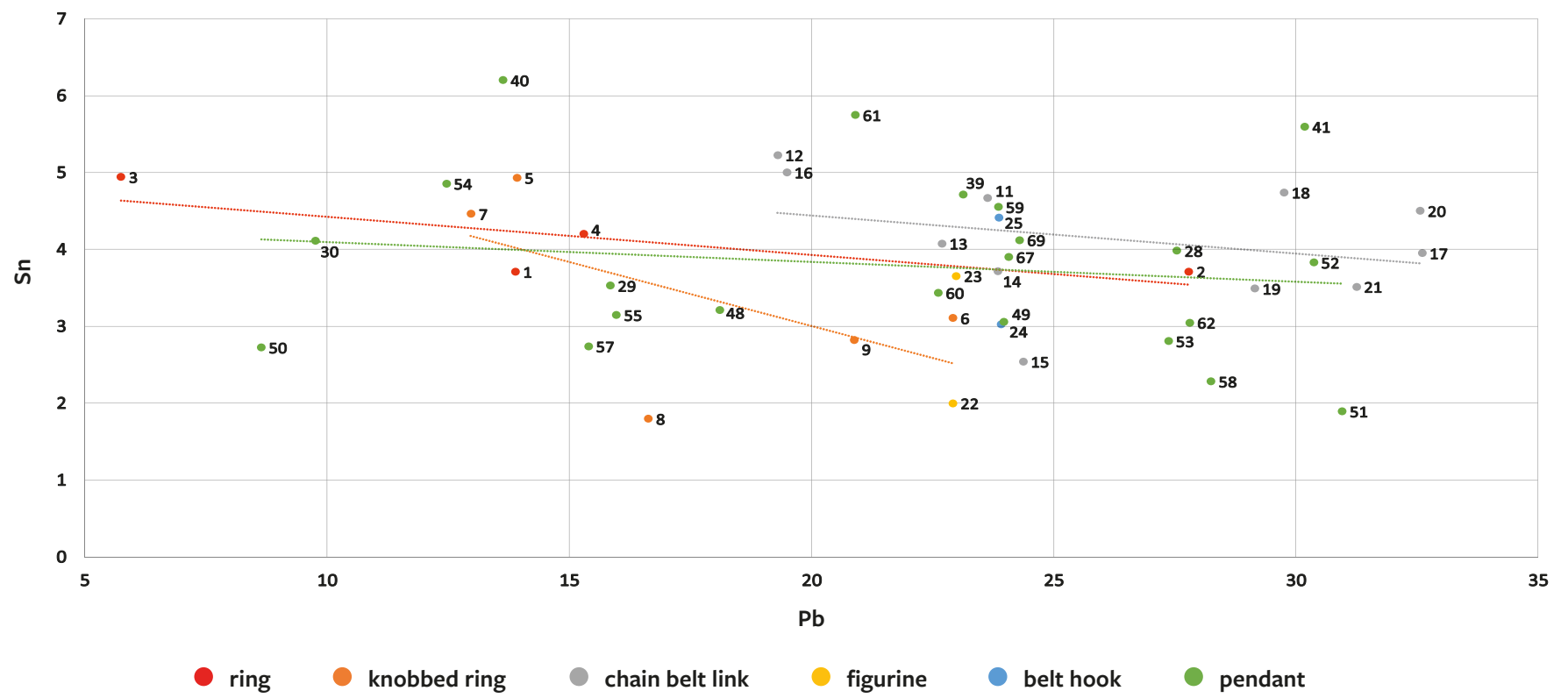

Graph 1. Graph of the $\mathrm{Pb} / \mathrm{Sn}$ content ratio in copper alloys artefacts according to bulk analysis results (numbers correspond to individual items in the catalogue part). Graf 1. Graf poměru koncentrace Pb/Sn v materiálu předmětů ze slitin mědi podle výsledků analýz kovového jádra (čísla odpovídajíjednotlivým položkám v katalogové části). 


\begin{tabular}{|c|c|c|c|c|c|c|c|c|c|c|c|c|c|c|c|c|c|c|c|}
\hline ID & Artefact & $\mathbf{C u}$ & $\mathbf{P b}$ & Sn & $\mathbf{Z n}$ & Sb & $\mathbf{B i}$ & $\mathbf{A g}$ & Co & $\mathbf{N i}$ & $\mathrm{Au}$ & $\mathrm{Fe}$ & Si & $\mathbf{P}$ & Mn & $\mathbf{T i}$ & $\mathbf{Z r}$ & Cr & $\mathbf{v}$ \\
\hline 1 & ring & 29.12 & 37.48 & 30.40 & 0 & 0 & 0 & 0 & 0 & 0 & 0 & 3.00 & 0 & 0 & 0 & 0 & 0 & 0 & 0 \\
\hline 2 & chain belt link & 42.01 & 34.09 & 22.49 & 0.12 & 0.19 & 0.31 & 0.21 & 0 & 0 & 0 & 0.46 & 0 & 0 & 0 & 0 & 0.03 & 0 & 0 \\
\hline 3 & pendant & 24.57 & 41.09 & 31.32 & 0.10 & 0.16 & 1.60 & 0 & 0 & 0 & 0 & 0.62 & 0 & 0 & 0 & 0.34 & 0.03 & 0.13 & 0.11 \\
\hline 4 & pendant & 49.36 & 32.24 & 16.70 & 0.22 & 0.20 & 0.18 & 0.22 & 0 & 0 & 0 & 0.20 & 0 & 0 & 0 & 0.37 & 0 & 0 & 0.20 \\
\hline 5 & figurine & 52.00 & 30.84 & 9.23 & 0 & 1.37 & 0 & 0 & 0 & 0 & 0.26 & 0.17 & 6.14 & 0 & 0 & 0 & 0 & 0 & 0 \\
\hline 6 & knobbed ring & 51.52 & 22.14 & 25.93 & 0 & 0.32 & 0 & 0 & 0 & 0 & 0 & 0.09 & 0 & 0 & 0 & 0 & 0 & 0 & 0 \\
\hline 7 & pendant & 37.44 & 43.49 & 16.04 & 0.35 & 1.02 & 0.20 & 0 & 0 & 0.14 & 0 & 1.07 & 0 & 0 & 0 & 0.23 & 0 & 0 & 0 \\
\hline 8 & knobbed ring & 26.78 & 36.03 & 32.66 & 0.09 & 0.80 & 0.41 & 0.73 & 0 & 0.13 & 0 & 2.35 & 0 & 0 & 0 & 0 & 0.03 & 0 & 0 \\
\hline 9 & pendant & 38.91 & 30.19 & 28.03 & 0.45 & 0.34 & 0.87 & 0.41 & 0 & 0 & 0 & 0.79 & 0 & 0 & 0 & 0 & 0.02 & 0 & 0 \\
\hline 11 & chain belt link & 37.10 & 33.26 & 28.38 & 0 & 0.58 & 0 & 0 & 0 & 0.12 & 0.13 & 0.44 & 0 & 0 & 0 & 0 & 0 & 0 & 0 \\
\hline 12 & chain belt link & 54.18 & 28.43 & 16.11 & 0 & 0.90 & 0 & 0 & 0 & 0 & 0 & 0.38 & 0 & 0 & 0 & 0 & 0 & 0 & 0 \\
\hline 13 & chain belt link & 42.68 & 43.25 & 12.81 & 0 & 0.48 & 0 & 0.19 & 0 & 0 & 0 & 0.57 & 0 & 0 & 0 & 0 & 0 & 0 & 0 \\
\hline 14 & chain belt link & 58.37 & 26.51 & 13.97 & 0 & 0.48 & 0 & 0.25 & 0 & 0 & 0 & 0.41 & 0 & 0 & 0 & 0 & 0 & 0 & 0 \\
\hline 15 & chain belt link & 68.00 & 16.38 & 14.27 & 0 & 0.17 & 0.40 & 0.21 & 0 & 0.11 & 0 & 0.18 & 0 & 0 & 0 & 0 & 0 & 0 & 0 \\
\hline 16 & pendant & 60.17 & 19.74 & 19.45 & 0 & 0 & 0 & 0 & 0 & 0.06 & 0.19 & 0.20 & 0 & 0 & 0 & 0.20 & 0 & 0 & 0 \\
\hline 17 & pendant & 31.99 & 40.18 & 25.19 & 0 & 0.16 & 0.91 & 0.67 & 0 & 0 & 0 & 0.39 & 0 & 0 & 0 & 0 & 0 & 0 & 0 \\
\hline 18 & pendant & 70.79 & 20.26 & 8.15 & 0.01 & 0.18 & 0 & 0 & 0 & 0.05 & 0 & 0.20 & 0 & 0 & 0 & 0 & 0 & 0 & 0 \\
\hline 19 & pendant & 55.93 & 29.98 & 12.78 & 0 & 0.62 & 0 & 0.25 & 0 & 0 & 0 & 0.16 & 0 & 0 & 0 & 0 & 0 & 0 & 0 \\
\hline 20 & pendant & 71.64 & 17.30 & 9.32 & 0 & 0.45 & 0.19 & 0.28 & 0 & 0 & 0 & 0.06 & 0 & 0 & 0 & 0 & 0 & 0 & 0 \\
\hline 21 & pendant & 57.21 & 35.20 & 5.33 & 0 & 1.42 & 0 & 0.34 & 0 & 0 & 0 & 0 & 0 & 0 & 0 & 0 & 0 & 0 & 0 \\
\hline 22 & pendant & 47.61 & 32.37 & 17.71 & 0 & 0 & 0.90 & 0 & 0 & 0 & 0.13 & 1.28 & 0 & 0 & 0 & 0 & 0 & 0 & 0 \\
\hline 23 & pendant & 65.29 & 27.87 & 6.84 & 0 & 0 & 0 & 0 & 0 & 0 & 0 & 0 & 0 & 0 & 0 & 0 & 0 & 0 & 0 \\
\hline 24 & ring & 24.88 & 49.31 & 25.04 & 0 & 0 & 0 & 0 & 0 & 0 & 0 & 0.77 & 0 & 0 & 0 & 0 & 0 & 0 & 0 \\
\hline 25 & ring & 53.11 & 26.81 & 17.74 & 1.68 & 0 & 0 & 0 & 0 & 0 & 0 & 0.65 & 0 & 0 & 0 & 0 & 0 & 0 & 0 \\
\hline 28 & chain belt link & 30.08 & 33.43 & 34.41 & 0 & 0.30 & 0.18 & 0 & 0 & 0 & 0 & 0.70 & 0 & 0 & 0 & 0.59 & 0.03 & 0.12 & 0.11 \\
\hline 29 & ring pendant & 47.52 & 24.21 & 23.33 & 0.14 & 0.25 & 0.07 & 0 & 0 & 0.07 & 0 & 0.16 & 1.90 & 2.33 & 0 & 0 & 0.02 & 0 & 0 \\
\hline 30 & ring & 37.14 & 28.57 & 34.29 & 0 & 0 & 0 & 0 & 0 & 0 & 0 & 0 & 0 & 0 & 0 & 0 & 0 & 0 & 0 \\
\hline 39 & figurine & 47.33 & 29.04 & 21.09 & 0.03 & 0.84 & 0.17 & 0.50 & 0 & 0.06 & 0 & 0.67 & 0 & 0 & 0 & 0.24 & 0.02 & 0 & 0 \\
\hline 40 & pendant & 35.24 & 45.58 & 17.35 & 0.16 & 0.37 & 0.51 & 0 & 0 & 0.10 & 0 & 0.37 & 0 & 0 & 0 & 0.28 & 0.04 & 0 & 0 \\
\hline 41 & pendant & 26.68 & 45.38 & 24.20 & 0.67 & 0.38 & 0.67 & 0 & 0 & 0 & 0 & 1.76 & 0 & 0 & 0 & 0.23 & 0.04 & 0 & 0 \\
\hline 48 & knobbed ring & 65.89 & 21.17 & 11.28 & 0 & 0.22 & 0 & 0.65 & 0 & 0 & 0 & 0.28 & 0 & 0 & 0 & 0.15 & 0 & 0 & 0.10 \\
\hline 49 & chain belt link & 58.57 & 24.89 & 16.32 & 0 & 0 & 0 & 0 & 0 & 0.05 & 0 & 0.17 & 0 & 0 & 0 & 0 & 0 & 0 & 0 \\
\hline 50 & chain belt link & 69.64 & 15.88 & 10.02 & 0 & 0.18 & 0.38 & 0.27 & 0 & 0.11 & 0 & 0 & 3.06 & 0.47 & 0 & 0 & 0 & 0 & 0 \\
\hline 51 & pendant & 40.60 & 46.16 & 11.76 & 0 & 0.29 & 0.17 & 0.26 & 0 & 0.08 & 0 & 0.47 & 0 & 0 & 0 & 0 & 0.03 & 0 & 0 \\
\hline 52 & knobbed ring & 55.51 & 27.17 & 15.84 & 0 & 0.16 & 0 & 0 & 0 & 0 & 0 & 0.45 & 0 & 0 & 0 & 0.36 & 0 & 0 & 0.14 \\
\hline 53 & pendant & 66.67 & 19.21 & 13.05 & 0 & 0.18 & 0.15 & 0 & 0 & 0 & 0 & 0.13 & 0 & 0 & 0 & 0.35 & 0 & 0 & 0.12 \\
\hline 54 & pendant & 74.31 & 19.96 & 5.14 & 0 & 0.04 & 0.23 & 0 & 0.09 & 0.05 & 0 & 0.10 & 0 & 0 & 0 & 0.11 & 0 & 0 & 0 \\
\hline 55 & pendant & 59.91 & 21.83 & 17.35 & 0 & 0.11 & 0.15 & 0 & 0.16 & 0 & 0 & 0.26 & 0 & 0 & 0 & 0 & 0 & 0 & 0 \\
\hline 57 & chain belt link & 51.92 & 38.58 & 9.09 & 0 & 0 & 0 & 0 & 0.10 & 0 & 0 & 0.30 & 0 & 0 & 0 & 0 & 0 & 0 & 0 \\
\hline 58 & belt hook & 64.11 & 21.72 & 13.82 & 0 & 0.09 & 0 & 0 & 0 & 0 & 0 & 0.17 & 0 & 0 & 0 & 0 & 0 & 0 & 0 \\
\hline 59 & chain belt link & 20.29 & 44.11 & 27.58 & 0 & 0 & 0 & 0 & 0 & 0 & 0 & 1.07 & 6.95 & 0 & 0 & 0 & 0 & 0 & 0 \\
\hline 60 & pendant & 54.47 & 31.03 & 13.12 & 0 & 0.90 & 0 & 0 & 0 & 0.08 & 0 & 0.41 & 0 & 0 & 0 & 0 & 0 & 0 & 0 \\
\hline 61 & pendant & 46.62 & 37.20 & 15.94 & 0 & 0 & 0 & 0 & 0 & 0 & 0 & 0.25 & 0 & 0 & 0 & 0 & 0 & 0 & 0 \\
\hline 62 & pendant & 41.59 & 46.99 & 10.51 & 0 & 0 & 0 & 0 & 0 & 0 & 0 & 0.79 & 0 & 0 & 0.11 & 0 & 0 & 0 & 0 \\
\hline 67 & knobbed ring & 51.78 & 16.08 & 29.93 & 0 & 0.31 & 0.24 & 0.22 & 0 & 0 & 0 & 0.64 & 0 & 0 & 0 & 0.43 & 0.02 & 0 & 0.10 \\
\hline 69 & belt hook & 35.89 & 40.22 & 19.04 & 0.03 & 2.67 & 0.24 & 0 & 0 & 0.16 & 0 & 1.61 & 0 & 0 & 0 & 0 & 0.02 & 0 & 0 \\
\hline 70 & belt hook & 39.01 & 25.32 & 33.79 & 0.12 & 0.34 & 0.38 & 0.32 & 0 & 0 & 0 & 0.37 & 0 & 0 & 0 & 0 & 0.02 & 0 & 0 \\
\hline
\end{tabular}

Tab. 3. Results of pXRF surface analysis of copper alloys artefacts (numbers correspond to individual items in the catalogue part).

Tab. 3. Výsledky pXRF prvkové analýzy povrchu předmětů ze slitin mědi (čísla odpovídají jednotlivým položkám v katalogové části). 
New metal and glass finds from the Late Iron Age in South Moravia (CZ). The contribution of citizen science to knowledge...

\begin{tabular}{|c|c|c|c|c|c|c|c|c|c|c|c|c|}
\hline ID & Artefact & $\mathrm{Cu}$ & $\mathrm{Pb}$ & Sn & $\mathrm{Zn}$ & Sb & Bi & $\mathrm{Ag}$ & Co & $\mathrm{Ni}$ & $\mathrm{Au}$ & $\mathrm{Fe}$ \\
\hline 1 & ring & 81.60 & 13.89 & 3.71 & 0.643 & 0.079 & $<0.078$ & 0.04 & 0.008 & $<0.028$ & 0.029 & $<0.059$ \\
\hline 2 & chain belt link & 71.28 & 23.64 & 4.67 & $<0.049$ & 0.058 & 0.218 & 0.03 & 0.064 & 0.041 & $<0.018$ & $<0.053$ \\
\hline 3 & pendant & 67.75 & 27.54 & 3.98 & $<0.054$ & 0.023 & 0.576 & 0.107 & 0.013 & 0.009 & $<0.020$ & $<0.058$ \\
\hline 4 & pendant & 80.39 & 15.85 & 3.53 & $<0.051$ & $<0.012$ & 0.145 & 0.03 & 0.029 & 0.029 & $<0.020$ & $<0.053$ \\
\hline 5 & figurine & 74.71 & 22.92 & 2.00 & $<0.080$ & 0.331 & $<0.144$ & $<0.014$ & 0.013 & 0.027 & $<0.035$ & $<0.092$ \\
\hline 6 & knobbed ring & 80.86 & 13.92 & 4.93 & $<0.046$ & 0.084 & 0.117 & 0.039 & 0.011 & 0.035 & $<0.016$ & $<0.048$ \\
\hline 7 & pendant & 85.57 & 9.77 & 4.12 & $<0.048$ & 0.266 & $<0.057$ & 0.067 & 0.007 & 0.051 & 0.027 & 0.129 \\
\hline 8 & knobbed ring & 73.57 & 22.91 & 3.11 & $<0.059$ & 0.123 & 0.173 & 0.037 & 0.022 & 0.053 & $<0.023$ & $<0.068$ \\
\hline 9 & pendant & 71.67 & 23.13 & 4.72 & $<0.057$ & 0.066 & 0.343 & 0.02 & 0.039 & 0.013 & $<0.024$ & $<0.063$ \\
\hline 11 & chain belt link & 75.11 & 19.30 & 5.23 & $<0.046$ & 0.137 & 0.128 & 0.023 & 0.035 & 0.037 & $<0.017$ & $<0.051$ \\
\hline 12 & chain belt link & 72.70 & 22.69 & 4.08 & $<0.052$ & 0.263 & 0.142 & 0.067 & 0.014 & 0.045 & $<0.019$ & $<0.057$ \\
\hline 13 & chain belt link & 71.88 & 23.85 & 3.72 & $<0.053$ & 0.301 & 0.141 & 0.054 & $<0.026$ & 0.051 & $<0.020$ & $<0.057$ \\
\hline 14 & chain belt link & 72.88 & 24.37 & 2.54 & $<0.054$ & 0.12 & $<0.097$ & 0.013 & 0.036 & 0.037 & $<0.020$ & $<0.061$ \\
\hline 15 & chain belt link & 75.07 & 19.49 & 5.00 & $<0.050$ & 0.056 & 0.265 & 0.055 & 0.038 & 0.024 & $<0.018$ & $<0.053$ \\
\hline 16 & pendant & 79.90 & 13.64 & 6.20 & $<0.048$ & 0.053 & 0.091 & $<0.004$ & 0.067 & 0.029 & 0.022 & $<0.049$ \\
\hline 17 & pendant & 63.20 & 30.18 & 5.60 & $<0.047$ & 0.031 & 0.802 & 0.154 & 0.017 & 0.013 & $<0.016$ & $<0.049$ \\
\hline 18 & pendant & 78.39 & 18.10 & 3.21 & $<0.045$ & 0.073 & 0.119 & 0.011 & 0.065 & 0.035 & $<0.015$ & $<0.046$ \\
\hline 19 & pendant & 72.51 & 23.97 & 3.06 & $<0.046$ & 0.19 & 0.171 & 0.045 & 0.023 & 0.037 & $<0.015$ & $<0.047$ \\
\hline 20 & pendant & 88.14 & 8.64 & 2.73 & $<0.044$ & 0.176 & 0.087 & 0.086 & 0.016 & 0.061 & $<0.015$ & 0.069 \\
\hline 21 & pendant & 66.30 & 30.96 & 1.90 & $<0.046$ & 0.664 & $<0.082$ & 0.16 & $<0.022$ & $<0.022$ & 0.028 & $<0.047$ \\
\hline 22 & pendant & 64.66 & 30.37 & 3.83 & $<0.049$ & 0.03 & 0.672 & 0.14 & 0.045 & 0.022 & $<0.017$ & 0.236 \\
\hline 23 & pendant & 69.43 & 27.37 & 2.81 & $<0.045$ & 0.09 & 0.228 & 0.037 & 0.013 & 0.028 & $<0.015$ & $<0.047$ \\
\hline 28 & chain belt link & 63.14 & 32.60 & 3.95 & $<0.048$ & 0.04 & 0.234 & $<0.005$ & 0.016 & 0.016 & $<0.017$ & $<0.053$ \\
\hline 29 & ring pendant & 82.51 & 12.46 & 4.86 & $<0.050$ & 0.078 & $<0.069$ & 0.012 & 0.032 & 0.046 & $<0.019$ & $<0.052$ \\
\hline 30 & ring & 80.08 & 15.30 & 4.21 & $<0.057$ & 0.041 & 0.256 & 0.029 & 0.058 & 0.041 & $<0.022$ & $<0.063$ \\
\hline 39 & figurine & 72.92 & 22.99 & 3.66 & $<0.048$ & 0.175 & 0.143 & 0.058 & 0.034 & 0.027 & $<0.016$ & $<0.049$ \\
\hline 40 & pendant & 80.47 & 15.97 & 3.15 & $<0.045$ & 0.091 & 0.151 & 0.041 & 0.025 & 0.096 & $<0.015$ & $<0.045$ \\
\hline 41 & pendant & 81.44 & 15.40 & 2.74 & $<0.045$ & 0.079 & 0.159 & 0.059 & 0.052 & 0.053 & 0.015 & $<0.045$ \\
\hline 48 & knobbed ring & 81.92 & 12.97 & 4.46 & $<0.050$ & 0.079 & 0.105 & 0.289 & 0.016 & 0.052 & $<0.019$ & 0.108 \\
\hline 49 & chain belt link & 65.16 & 29.76 & 4.74 & $<0.048$ & 0.075 & 0.211 & 0.006 & 0.022 & 0.025 & $<0.017$ & $<0.053$ \\
\hline 50 & chain belt link & 66.56 & 29.15 & 3.49 & $<0.051$ & 0.085 & 0.5 & 0.107 & 0.016 & 0.091 & $<0.018$ & $<0.054$ \\
\hline 51 & pendant & 69.03 & 28.25 & 2.29 & $<0.049$ & 0.081 & 0.192 & 0.07 & 0.008 & 0.086 & $<0.017$ & $<0.052$ \\
\hline 52 & knobbed ring & 75.99 & 20.88 & 2.82 & $<0.075$ & 0.058 & 0.162 & $<0.014$ & 0.046 & 0.046 & $<0.035$ & $<0.090$ \\
\hline 53 & pendant & 71.32 & 23.86 & 4.55 & $<0.052$ & $<0.012$ & 0.209 & 0.028 & 0.015 & 0.017 & $<0.019$ & $<0.054$ \\
\hline 54 & pendant & 73.33 & 22.62 & 3.44 & $<0.047$ & 0.016 & 0.408 & 0.076 & 0.097 & 0.019 & $<0.016$ & $<0.048$ \\
\hline 55 & pendant & 71.33 & 20.90 & 5.75 & 1.546 & 0.051 & 0.162 & 0.021 & 0.119 & 0.026 & 0.097 & $<0.062$ \\
\hline 57 & chain belt link & 62.46 & 32.56 & 4.50 & $<0.048$ & 0.081 & 0.232 & $<0.005$ & 0.127 & 0.033 & $<0.018$ & $<0.053$ \\
\hline 58 & belt hook & 68.87 & 27.81 & 3.05 & $<0.054$ & 0.035 & 0.195 & $<0.006$ & 0.022 & 0.023 & $<0.020$ & $<0.060$ \\
\hline 59 & chain belt link & 64.84 & 31.25 & 3.52 & $<0.046$ & 0.059 & 0.238 & 0.025 & 0.05 & 0.024 & $<0.017$ & $<0.051$ \\
\hline 60 & pendant & 71.51 & 24.07 & 3.90 & $<0.050$ & 0.299 & 0.149 & 0.036 & 0.014 & 0.024 & $<0.018$ & $<0.053$ \\
\hline 61 & pendant & 71.10 & 24.30 & 4.12 & $<0.050$ & 0.119 & 0.187 & 0.036 & 0.104 & 0.036 & $<0.017$ & $<0.052$ \\
\hline 62 & pendant & 77.87 & 19.26 & 2.55 & $<0.045$ & 0.046 & 0.153 & 0.064 & 0.011 & 0.027 & 0.019 & $<0.047$ \\
\hline 67 & knobbed ring & 81.25 & 13.82 & 4.64 & $<0.063$ & 0.063 & 0.088 & $<0.010$ & 0.09 & 0.042 & $<0.028$ & $<0.070$ \\
\hline
\end{tabular}

Tab. 4. Results of ED-XRF bulk analysis of copper alloys artefacts (numbers correspond to individual items in the catalogue part).

Tab. 4. Výsledky ED-XRF prvkové analýzy vzorků kovového jádra předmětů ze slitin mědi (čísla odpovídají jednotlivým položkám v katalogové části). 
Bulk analysis showed that the artefacts were made of three-component high leaded tin bronze with an admixture (<1 wt.\%) of antimony, bismuth, silver, cobalt, nickel and, exceptionally, zinc, gold and iron (Tab. 4). The lead content in the individual artefacts ranges from 5.75 to $32.6 \%$ (on average $21.79 \%$ ), while the tin concentration has a much narrower variance in the range from 1.9 to $6.2 \%$ (on average 3.85\%; Graph 1). This representation of the main alloying elements is typical for the La Tène period (Frána et al. 1997; Kmošek 2019). In comparison with the analysed assemblage of copper alloys artefacts from the Trrísov oppidum (Danielisová et al. 2018b), the studied group from south Moravia shows a significantly smaller content of tin and a high content of lead. Such a high proportion of lead (above 20\%) is found in the Tř́sov group in most of the 'amulets' and in about a quarter of imported vessels (Danielisová et al. 2018b, tab. 1). Whether the composition of alloys is conditioned by the availability of raw materials or technological or aesthetic requirements (cf. Danielisová et al. 2020) cannot be assessed with the limited number of published analysis.

Although the representativeness of the assemblage is statistically relatively low in terms of the volume of input data and other aspects (spatial distribution), the above stated observations can also be tested using formalised methods of investigating structures in the data on the basis of standardly used cluster analysis. The results presented in the form of a dendrogram arrange the mutual distances (similarities) of individual tested objects (artefacts) in latent space. Only the three main elements $\mathrm{Cu}, \mathrm{Pb}$ and $\mathrm{Sn}$ - were considered for evaluation. Other detected elements were not considered due to their negligible statistical significance (detected content usually does not exceed 10\%; in total they do not make up more than $2 \%$; see Tab. 4). ${ }^{3}$ Based on the results of bulk analysis, the composition of the artefacts can be characterised as relatively homogeneous from the statistical point of view. The highest variability can be observed in the representation of lead (interval range $26.9 \%$, standard deviation 6.7). This aspect was then most pronounced in the arrangement of the tested artefacts in the clusters of the resulting dendrogram (the input settings of the analysis included the Euclidean distance when defining the distances between the artefacts and the complete interconnection; Graph 2). Arbitrarily, a meaningful cluster distance threshold can be sought in the range of about 7-15 ( $y$-axis), where 3-6 clusters can be identified. A distance of 10 with the distribution of artefacts into four (containing 13, 21, 3 and 10 objects) clusters variable by number then seems to be optimal (Graph 3). The first three clusters in the direction from the beginning of the axis can generally be identified with the decreasing proportion of lead in the alloy (average value 29.8\%, $23 \%$ and $8.6 \%$ ) and directly proportional to the increasing content of copper, while the tin content does not differ between clusters (average 4\%). In the context of the analysed artefacts, a specific group is represented by the fourth cluster, which, on the contrary, shows a high representation of tin, where tin and lead have an almost identical representation (the average for both elements is $14.6 \%$ ). This cluster also shows a low variance of the recorded copper content in the alloy.

When investigating technological and functional contexts in the studied data set, the principal means of external validation is the comparison of identified structures (clusters) and the type (functional or morphological) determination of the analysed artefacts. Despite the generally observable lower correlation of these two parameters, where, for example, significantly represented pendants (nearly half of all determined metal objects) are relatively evenly distributed in all clusters, compared to similarly numerous belt links, which do not occur in the third and fourth cluster. Here, on the other hand, knobbed rings (three of four determinations) and, in a similar representation, also objects intended as rings without further differentiation, are most often evidenced. The determinations 'figurine' and 'belt hook', which are insignificant in number, then occur exclusively in the most numerous second cluster. At the same time, it is evident that this largest cluster is represented by a relatively consistent dispersion of values and the closest relationships of artefacts at clustering distances, often $\leq 1$, are also apparent. However, due to the limited number of input objects, no representative structures can be identified with the statistics in the data for the relevant technological links between alloy composition and functional determination.

Within individual groups of artefacts, certain specific similarities or, conversely, differences, were found in typologically similar artifacts. For example, a pair of belt links from Drnholec - Roviny

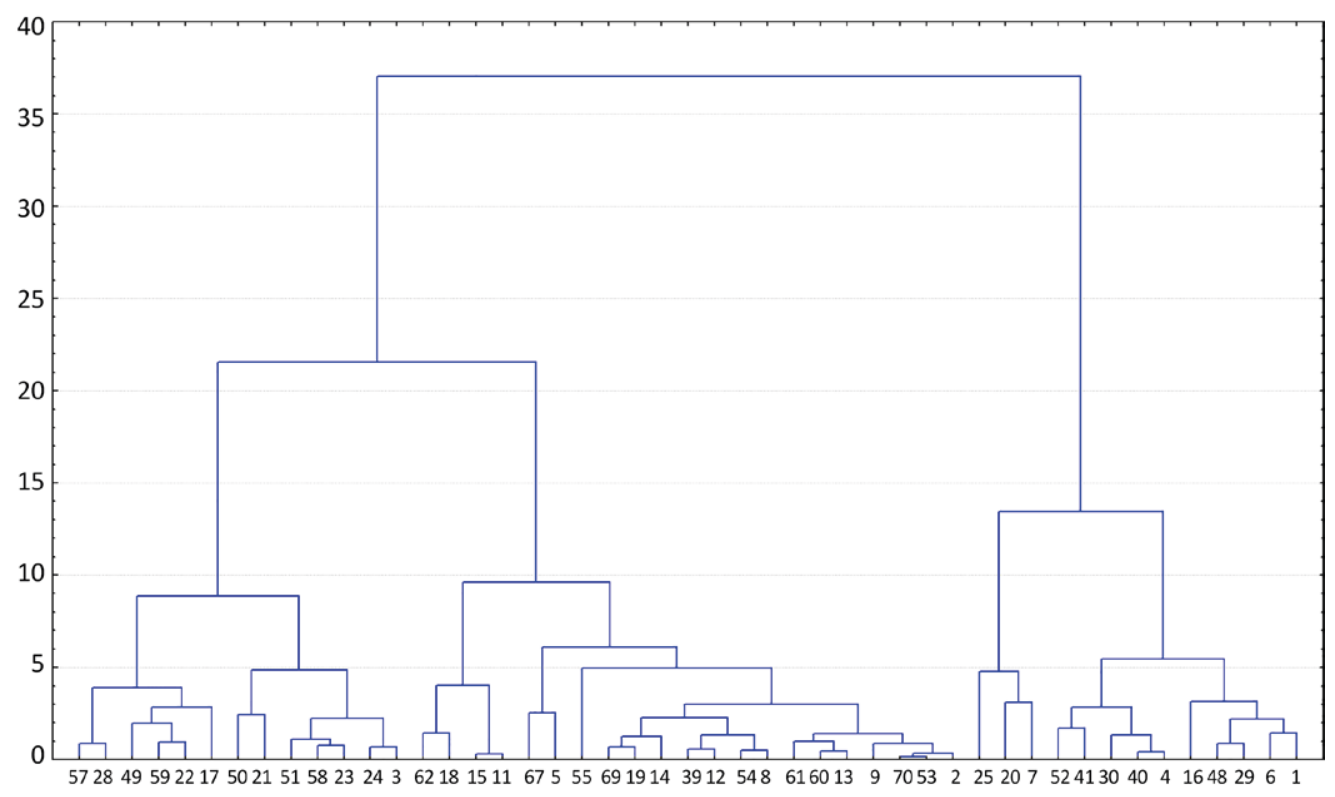

Graph 2. Dendrogram of the cluster analysis of the elemental composition bulk analysis (numbers correspond to individual items in the catalogue part). Graf 2. Dendrogram shlukové analýzy prvkového složení predmětů podle výsledků analýz kovového jádra (čísla odpovídají jednotlivým položkám vkatalogové části). 


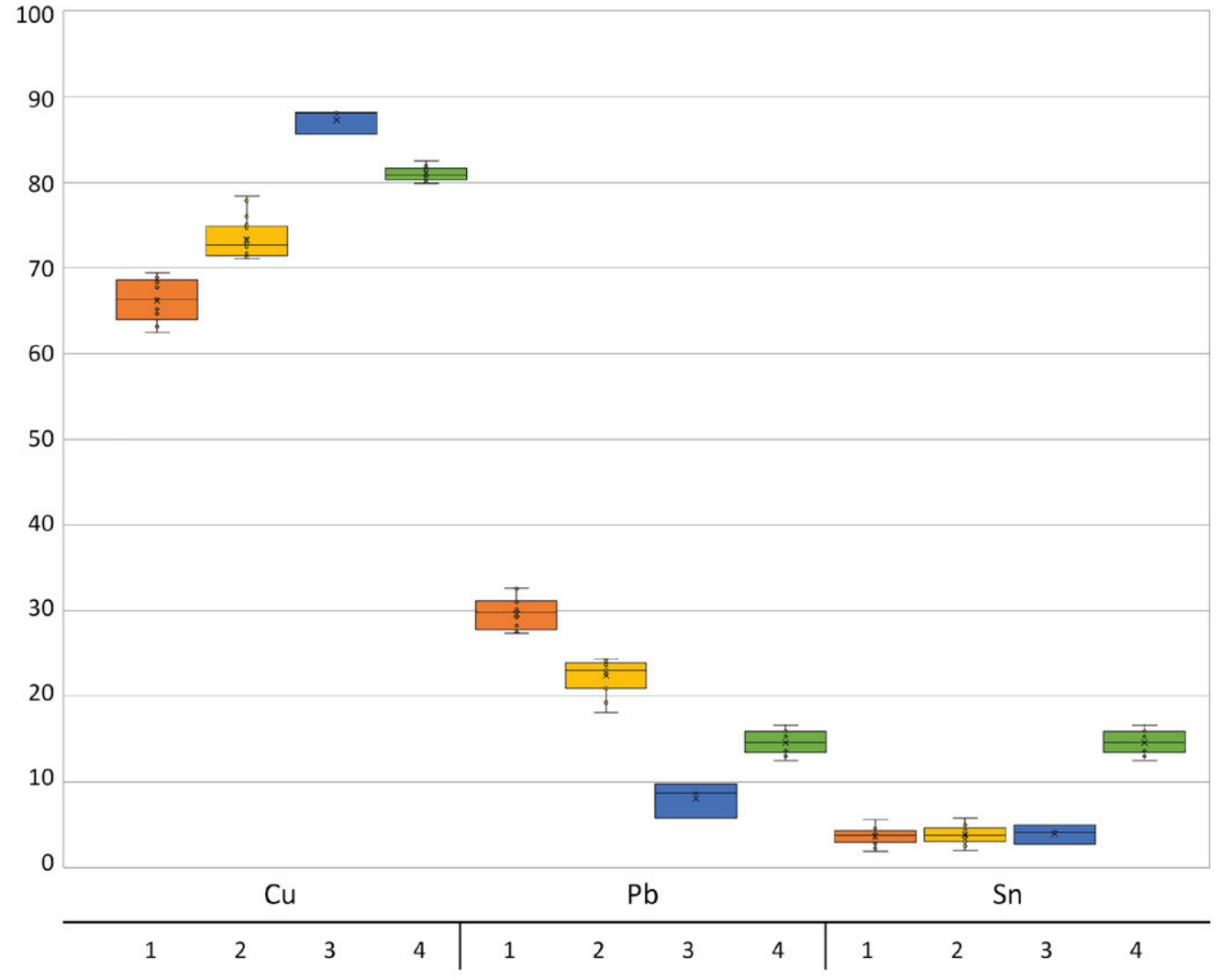

Graph 3. Box plot comparing the variances of the percentage of main elements within the four resulting clusters (distance 10, see Graph 2) of the cluster analysis.

Graf 3. Krabicový graf srovnání rozptylů procentuálního zastoupení hlavních prvků v rámci 4 výsledných shluků (vzdálenost 10, viz graf 2) shlukové analýzy.
(Cat. no. 12, 13; Fig. 3: 13, 14) alike in size, typology and decoration, shows a striking and specific similarity in alloy composition, which supports the assumption of their origin in the same belt chain. The pendant from Mušov - Na Pískách (Cat. no. 60; Fig. 4: 8) is also close to them in terms of alloy composition, despite coming from a different cadastral area. In contrast, a pair of morphologically highly similar rings with small knobs (Mikulov - U Aleje, Cat. no. 52 - Fig. 5: 9; Sedlec - Za Čelovským, Cat. no. 67 - Fig. 5: 15) have a diametrically different composition of the main alloy elements. Smooth undecorated rings generally correspond in terms of elemental composition to other artefacts dated therefore to the La Tène period. Their inclusion in that period is supported by this fact, although their typological classification in the La Tène period is not completely clear.

A possible distinguishing criterion explaining broad compositional inhomogeneity has yet to be identified for various belt components (links, pendants, hooks). More extensive conclusions in this regard would be made possible by the analysis of complete belt sets. Even in this case, however, it turns out that the individual parts of the same belt show a markedly different material composition (Čižmář et al. 2020, 115). Common types of belts could have been produced in large quantities and subsequently assembled regardless of the material composition of the individual components. Some unique belts could be made to order, which would be indicated by the material similarity of individual parts of the belt (see the aforementioned belt links from Drnholec - Roviny). Although the composition of belt links in general is quite inhomogeneous, the amount of lead in the alloy is typically around $30 \%$, while the tin content is less than $5 \%$. As the composition of the belt pendants is even more heterogeneous, the similar composition (with 16\% lead) of typologically similar pendants with a rectangular eyelet is striking (Cat. no. 4, 40, 41; Fig. 2: 4; 4: 5, 6 - cf. Tab. 4).

\section{Evaluation of artefacts}

\subsection{Figurines}

The studied assemblage contains two figurines depicting a human figure from the sites of Břeclav - Lúbež (Cat. no. 5; Fig. 2: 6) and Ladná - Padělky (Cat. no. 39; Fig. 4: 4). These have a consistent material composition with a similar share of $\mathrm{Cu}$ (74.7 and 72.9\%) and nearly identical lead content (c. 23\%). ${ }^{4}$ Small human figurines from the La Tène period have been discovered in Moravia only in recent years, without exception with the use of a metal detector (Čižmář 2012b; Goláňová, Kysela 2019). They are characterised by a certain production sloppiness and the inconsistent representation of the body and the position of the hands.

The figurine from Břeclav - Lúbež (Cat. no. 5; Fig. 2: 6) represents an upright naked human figure with his arms folded in the area of the abdomen, where there is a depression by the sternum down to roughly the waist. One of the hands seems to be pressed into this depression, while the other (with three fingers) is resting on the waist. The figurine has finely crafted features on the face with an elaborated nose (including marked nostrils), mouth and ears. As with the vast majority of these figurines, the eyes are holes/punctures that could have been filled with another material (silver alloy in the case of the find from Lednice - Podholmy: Goláňová, Kysela 2019, 78, Fig. 4). While the hair is almost indistinctly indicated by a few grooves above the forehead, the head looks bald due to the accurate design of the skull vault. Like most others, the figure does not stand on its own. In this case the legs are even slightly bent at the knees and the toes point slightly downwards, reminiscent of the depiction of a human figure on Early La Tène brooches from Manětín - Hrádek (Soudská 1994, 154-155, Abb. B13: 6; E17: 10-13) and Horné Orešany (Pieta 2008, F1: 4; 2010, 311, F1: 4). The figurine is not modelled on the back; it is almost flat and it does not have 
modelled buttocks - possibly originally intended for carrying/ hanging or laying. Although the male genitalia are clearly marked, the sex of the figure is not unambiguous; next to the depression in the chest, two protruding breasts are clearly shown. The cavity in the chest of the figure is not exceptional: it appears also on other figurines from Moravia (Němčice nad Hanou: Čižmář 2012b, Fig. 3: 3, 5) and Slovakia (Prašník: Pieta 2008, Fig. 130: 3; 2010, Abb. 130: 3; Čižmář 2012b, Fig. 1: 5). In addition to enamel, the inlay in the cavity could be made of an organic material or another substance. The figurine from Prašník is similar to the find from Břeclav - Lúbež, again thanks to the placement of the hands and the design of the breasts and male genitalia.

Some figurines were directly cast in parts (or parts of organic origin were to be added to the figurine): a figurine of a warrior with a shield from Trenčianske Bohuslavice (Pieta 2008, 304, F36: 3) has a hole in his hand, probably for inserting a spear.

The second figurine, found in Ladná - Padělky (Cat. no. 39; Fig. 4: 4), is roughly modelled and represents a standing human figure. Here, too, the sex of the figure is not entirely clear: the male genitalia stand out clearly horizontally, but the chest is noticeably thickened at the chest, though breasts are not modelled. The head is only suggested: large depressions represent the eyes, the nose is almost absent, and only a groove is marked in the place of the mouth/beneath the nose. The ears are missing. The hands have three fingers, with the left hand placed in the stomach area, the right resting on the hip. This exact same position of hands has not yet been found on other figurines, though the vast majority of figures have their hands arranged somewhere on the torso (cf. Čižmář 2012b). The legs are straight, flattened from above, and the feet are depicted horizontally (though the figure is not standing). The remains of the untreated surface after casting is visible on the buttocks.

Two finds from the Břeclav region significantly expand the number of finds from this area (Lednice, Podivín, Př́tluky) and adjacent Austria (Bernhardstahl) (cf. Čižmář 2012b; Goláňová, Kysela 2019, 78). The number of human figurines from the Břeclav region reaches the number found in Němčice nad Hanou, ${ }^{5}$ and the concentration in places near the Thaya River is surprising: the sites of Břeclav - Lúbež, Lednice - Podholmy and Ladná Padělky are separated by at most $2 \mathrm{~km}$ (and watercourses of the brooks or the Thaya). Although the location where the figurine was found in Podivín is not known, the cadastre is directly adjacent to Ladná, and Lednice and Př́tluky are about $6 \mathrm{~km}$ away. Despite the growing number of finds in the Břeclav region, we know almost nothing about the contexts from which they come. In Central Europe, finds of anthropomorphic figurines are concentrated mainly in the so-called Amber Route corridor, i.e., in the 'eastern zone of the Middle Danube region' (in Moravia, Upper Silesia, in the eastern part of Lower Austria and in west Slovakia). Based on a study of the distribution of coins and glass objects for which local production is assumed, this area also had a specific local identity (Venclová, Militký 2014), which may have included the production of small anthropomorphic figurines.

In comparision with the precisely crafted bronze jewellery of the La Tène period, human figurines from LT C-D look crude (cf. Goláňová, Kysela 2019, 78) and they may have been made by persons other than the craftsmen who made jewellery. Metalworking involved harnessing dangerous transformational forces (cf. Garrow, Gosden 2012, 13), and the use of different alloy compositions, including silver (Lednice - Podholmy) suggests that the production process and the material used (and the role of the manufacturer in the process?) could have been more important than the final representation of the human figure.

\subsection{Pendant in the form of an amphora-shaped vessel}

A unique find is the pendant from Břeclav - Přední čtvrtky in the form of an amphora-shaped vessel with a broken suspension loop, imitating the handle of metal vessels (Cat. no. 9; Fig. 2: 9). The vessel body tapers conically to a button-shaped bottom terminal. The decoration of the walls of the pendant with enamel in elongated triangular segments is unusual and has no parallel.

Vessel-shaped pendants are not a common find and have not yet received systematic attention for the later phases of the La Tène period. The artefact is most similar to basket-shaped pendants/'Körbchenanhänger' (cf. Čižmář 2002a), which, however, usually have a round bottom and a simple suspension loop/handle and are typical for northern Italy (especially the area of the Golasecca culture - cf. Faudino et al. 2014, 136, Fig. 14) and transalpine Europe in the Late Hallstatt period. Rare forms with a pointed bottom and a shaped neck come from Slovenia and indicate subsequent local development in the $5^{\text {th }}$ century BC (Teßmann 2007, 679, 691, Abb. 22; Laharnar 2018, 213-214, Anm. 148-149, 156; Fig. 7: 20).

The closest parallels to the pendant are found at the Staré Hradisko oppidum, from where two specimens are known: a small bronze situla (Meduna 1961, Taf. 1:12) with a similar rim shape and suspension method as the specimen from Břeclav, though with a flat bottom; ${ }^{6}$ another pendant, obtained at the oppidum in 1934 (Čižmář 2002a, 210, Fig. 10: 5) has a bottom that ends with a knob. ${ }^{7}$ Numerous pendants from a cremation burial in Neu Plötzin/D in Brandenburg (Hundt 1935, 241, Taf. 33: 8) have a bottom that ends in this manner (as well as a similar overall vessel shape). In this burial, those pendants were deposited with cremated remains in a bronze situla, along with, among other things, knobbed rings (Knotenringe), and the grave can be dated to the end of the $1^{\text {st }}$ century BC (Teuber 2017, 114).

Vessel-shaped pendants also come from Haselbach, where a hollow bucket-shaped pendant with vertical walls and a straight horizontal handle dated to LT C (Trebsche, Fichtl 2016a, 13, Abb. 21) was found, and two pendants are also known from Bernhardstahl-Wehrlehen - one decorated with knobs and crescent-shaped depressions, perhaps for enamel (Allerbauer, Jedlicka 2001, 614, 616, Abb. 530, 538). A pendant with conical walls ending with a button is also known from Čebovce (Čambal et al. 2017, Abb. 4: 38)..$^{8}$ A spherical pendant from Stradonice has an eyelet that also imitates the handle of bronze vessels (Píč 1906, Pl. XIII: 41). A pendant in the shape of a globular vessel is also captured in a photograph of the probably complete inventory of hoard 10/2005 from Plavecké Podhradie - Pohanská, though the artefact is no longer present in the preserved assemblage (cf. Čambal 2015, Fig. 3).

A basket-shaped (more so than bucket-shaped) pendant is also known from Němčice nad Hanou (Čižmář, Kolníková 2006, 264, Fig. 2: 2; Čižmář et al. 2010b, 660, Abb. 3: 2). It is possible that hollow pendants ${ }^{9}$ in the shape of a shoe from Němčice nad Hanou and other Moravian sites (Čižmář, Kolníková 2006, 264, Fig. 2: 3; Čižmář et al. 2010b, 660, Abb. 3: 3; Čižmář 2012b, 155, Fig. 7: 3-5; 8: 5, 8-9) are closer to vessel-shaped pendants than to solid cast specimens of the same form.

It is interesting that in Central Europe there is another artefact after shoe/foot pendants, which has the closest parallels in Italy in the $6^{\text {th }}$ and $5^{\text {th }}$ centuries BC (Čižmár $2012 b, 149-150$ ), but a number of finds in contexts from the $3^{\text {rd }}-1^{\text {st }}$ century BC clearly place it in this time period.

\subsection{Belt elements}

Belt links, hooks and pendants are frequent finds whose numbers are quickly growing thanks to the use of metal detectors. Metal belts were previously considered an indicator of elites 
based on the analysis of the graves, but now, due to their mass occurrence, they are mostly attributed to the 'middle-class' (Danielisová et al. 2018a, 166). Prior to the use of detectors, parts of women's belts were not, with few exceptions (Nejdek Pohansko: Novotný 1963, 16-17), known from settlements in the Břeclav region (cf. Čižmář 2002b), and in Moravia in general their finds outside cemeteries were rare (Křenovice, Mistř́n, Němčice nad Hanou: Meduna 1980a, Taf. 63: 10; 80: 9; 105: 11).

\subsubsection{Belt links and hooks}

Belt links and pendants in the studied assemblage can be divided into several groups:

- belt links with a (larger) annular central part and side plates - a total of four specimens: Drnholec - Roviny (three specimens - Cat. no. 12-14; Fig. 3: 13-15); a belt hook from Mušov - Na Pískách - Cat. no. 58; Fig. 4: 12 apparently also belongs to this type)

- belt links with a central globular element and side plates - a total of seven specimens: Břeclav - Hrudy (Cat. no. 2; Fig. 2: 2), Drnholec - Roviny (Cat. no. 15; Fig. 3: 12), Hrušky - Tvrdonické podsedky (Cat. no. 28; Fig. 4: 1), Mikulov - Nad Valtickou silnicí (two specimens - Cat. no. 49, 50; Fig. 5: 6-7), Mušov Na Pískách (two specimens - Cat. no. 57, 59; Fig. 4: 10-11)

- belt links with a 'roof-shaped' central part and side plates one specimen: Drnholec - Roviny (Cat. no. 11; Fig. 3: 11).

Two fragments of belt hooks/suspension hooks are difficult to classify (Velké Bílovice, Zaječí). The find from Velké Bílovice (Cat. no. 69; Fig. 5:13; belt hook in the form of a highly stylised horse head with a broken-off oval eyelet) represents perhaps the only fragment of a belt from links connected by rings, which otherwise appear frequently in graves (cf. Bujna 2011, 83-120, Čižmářová 2005, Fig. 75: 5; 2009, tab. 10: 1-2; 2011, tab. 42: 5-6; 54: 10; 2017, 183, 286, tab. 65: 7; 67: 10), also in the Břeclav region (Čižmářová 2019, tab. 4: 1; 12: 2-4; 25: 4-6).

Preserved from a belt hook from Zaječí (Cat. no. 70; Fig. 5: 16) is a side plate with chainlet holes connected by an oval segment to the part with the hook (the hook itself is broken off). The belt hook has a parallel in Sudice in the Třebíč region (Čižmář, Jarůšková 2019, 385, Fig. 7: 2), on which the hook had a zoomorphic head. Both belt hooks have the same spiral depression; enamel decoration has been preserved in this depression on the specimen from Sudice in the Třebíc region.

Finds from belt links with a large central annular part and side plates are concentrated in Drnholec, where three links were found (two of which could have been part of the same belt Cat. no. 12-14; Fig. 3: 13-15). This type of belt is relatively wellknown in Moravia from graves, ${ }^{10}$ but they also come from the agglomeration in Němčice nad Hanou (Čižmář, Kolníková 2006, 264, Fig. 5: 6; Čižmář et al. 2010b, 661, Abb. 8: 6). While in Hulín, Charváty and Němčice nad Hanou, the ribs flanks the central ring and the plate is connected by a tapered neck (the belt hook from Mušov - Na Pískách is also formed in the same way: Cat. no. 58; Fig. 4: 12), on all three links from Drnholec the side plates with three holes are connected directly to the central ring and are only separated by a thin rib. The side plates on the belt hook from Křepice are connected in the same way but have only two chainlet holes. They can probably be dated to the end of LT C1 or the beginning of LT C2 (Tajer 2009; Bujna 2011, 143; cf. Venclová 2016, 29).

Two elements, apparently from the same belt, have been preserved from Drnholec: ${ }^{11}$ the link has a central annular part decorated with engraved triangles composed in groups of three (Cat. no. 12-13; Fig. 3: 13-14). The triangles were probably originally decorated with enamel. Side plates with three holes were attached to the central annular part. On one of the links, one of the plates is replaced by a pair of protruding strips (unfortunately broken off), which probably formed part of the belt fastener (cf. Charváty: Čižmářová 2017, 144, tab. 50: 6). Another slenderer belt link ${ }^{12}$ from Drnholec (Cat. no. 14; Fig. 3:15) is decorated with arch-shaped depressions (originally probably for enamel) also directly on the central annular part, while on the belts decorated with enamel from Hulín, Charváty and Bernhardstahl, the side plates are decorated with a similar motif, not the central annular part (Tajer 2009; Čižmářová 2017, 143-144, 255, tab. 50: 2, 5; Allerbauer, Jedlicka 2001, 614, Abb. 534).

Preserved from the belt hook from Mušov - Na Pískách (Cat. no. 58; Fig. 4: 12) is the broken-off central annular part, flanked by a narrow plate with a depression in the shape of a 'biconcave lens' and part of the hook connected to it. The hook of the belt hook from Mušov is broken off and could originally have been in the shape of a horse head, as is suggested by the shaping of the belt hook at the point where it is broken off (cf. zoomorphic belt hook from Němčice nad Hanou: Čižmář, Kolníková 2006, Fig. 5: 10; Čižmář et al. 2010, Abb. 8: 10). Preserved in the plate depression is red enamel decorated with incised decoration in the form of vertical hatching; fragments of links/belt hooks from Charváty (Čižmářová 2017, tab. 49: 12) and Střelice Padělky (Čižmářová 2011, tab. 51: 6) have the same decoration. The belt hook has a parallel in the belt element from Hulín, where the central annular part and adjacent side plate were preserved (Tajer 2009, Fig. 2: 1, Photo 5).

Belts with a central globular element (a total of seven specimens) make up the largest group of belt links in the assemblage. This type is also predominant in Němčice nad Hanou (Čižmářr, Kolníková 2006, 264, Fig. 5: 1-3; Čižmář et al. 2010b, 661, Abb.8: 1-3); since it is missing completely at cemeteries, the occurrence of this type is assumed from LT C2, especially in the Middle Danube region (Mangel, Jošková 2019, 469). All studied belt links from the Břeclav region have a large central globular element with ribs on the sides, separated from the side plates by a tapered neck (with the exception of the Hrušky specimen, on which the central globular element is connected directly to the side plates - Cat. no. 28; Fig. 4: 1). All of the links have three chainlet holes in the side plates; only the belt link from Mikulov Nad Valtickou silnicí (Cat. no. 49; Fig. 5: 6) had apparently two holes in the trapezoidal side plates. Despite a number of similarities, the individual specimens differ in size and in the details of their shape: on some links (Břeclav - Hrudy: Cat. no. 2 - Fig. 2: 2, Mikulov - Nad Valtickou silnicí: Cat. no. 50 - Fig. 5: 7, Drnholec Roviny: Cat. no. 15 - Fig. 3: 12), the rectangular side plates are narrow and the holes for the chainlets are located approximately in their centre. In contrast, both belt links from Mušov - Na Pískách (Cat. no. 57, 59; Fig. 4: 10-11) have wide side plates and the chainlet holes in them are placed along the outer edge (cf. Selec, Trenčín district/Slovakia - Pieta 2008, Fig. 72: 14-16). The same shape have the belt links from Haselbach, which are part of a belt chain ending with a zoomorphic hook (Trebsche, Fichtl 2016b, 33, Abb. 13).

Belts with a central globular element (with three holes in each side plate - cf. Mangel, Jošková 2019) also occurred in the Břeclav region in Boleradice (Čižmář et al. 2010a, Fig. 7: 1), with similar finds from Slovakia: Bratislava - Devínska Kobyla and Slovenský Grob (Čambal 2008, Fig. 4: 13; 2011, Tab. XI: 2; Budaj, Čambal 2016, 278, Fig. 5: 10-20). A similar type of link is known from Medlovice in the Vyškov district (Čižmář et al. 2009, Fig. 5: 7), although those from the Břeclav region have a slenderer central globular element. 
In the assemblage, there were no belt links with a profiled outer edge - a rib that extends beyond the sides of the rectangular plate. These formed part of the almost completely preserved belt from Hluboká u Kunštátu (Čižmář, Jarůšková 2019) and they also occurred in Němčice nad Hanou (Čižmář, Kolníková 2006, Fig. 5: 3; Čižmář et al. 2010b, Abb. 8: 3) and perhaps therefore represent a characteristic variant of a belt with a central globular element in central Moravia.

The casting of a belt link with a central globular element from Hrušky - Tvrdonické podsedky (Cat. no. 28; Fig. 4: 1) probably failed: there is a large irregular hole in one of the side plates and the belt link has unworked edges and an unremoved sprue on one of the plates. This belt link type was also common in Němčice nad Hanou (where it was also produced) and is classified - like other types with a central globular element - in LT C2 (Čižmářr, Kolníková 2006, 264, Fig. 5: 2; Čižmář et al. 2010b, 661, Abb. 8: 2). The find from Hrušky - Tvrdonické podsedky together with the find from Bernhardsthal (Allerbauer, Jedlicka 2001, 616, Abb. 555) represent the rare evidence of belt production in the region.

Compared to belts with a central annular part, belts made of links with a central globular element were significantly smaller and less striking: the height of the side plates on the belt link from Drnholec - Roviny (Cat. 12; Fig. 3:13) is double the smallest link from Mikulov - Nad Valtickou silnicí (Cat. 50; Fig. 5: 7). On the belt link from Mikulov - Nad Valtickou silnicí (Cat. no. 49; Fig. 5: 6) the side plates are sharply offset from the central globular element and are also considerably thinner than the flanking neck - possibly in this case the side plates were originally lined/ decorated with inserts made of organic materials (wood, leather?).

No parallels could be found in Moravia for the belt link with a roof-shaped middle part from Drnholec - Roviny (Cat. no. 11; Fig. 3: 11), decorated with enamel.

While a future complete study will certainly bring more detailed information on the chronology and distribution of women's belts from LT C2-D, it seems that one type of belt has variants occurring mainly in smaller regions. For example, for belts composed of links with a central globular element and side plates, which occur mainly in Moravia, southwest Slovakia, Lower Austria and Burgenland (Mangel, Jošková 2019), we propose the variants typical for south (links with a central globular element separated by ribs and a thin neck) and central Moravia (links with an outer rib extending past the rectangular plates on the sides).

\subsubsection{Pendants}

With 20 finds, belt pendants rank among the most numerous artefacts in the studied assemblage. They were found at Břeclav Hrudy (two specimens), Břeclav - Nivečky, Drnholec - Roviny (eight specimens), Ladná - Padělky, Lanžhot - Horní Štěpnice, Mikulov - U Aleje (three specimens), Mikulov - Nad Valtickou silnicí and Mušov - Na Pískách (three specimens).

The majority of pendants have a vase-shaped/conical form with the exception of specimens from Mušov - Na Pískách (Cat. no. 62; Fig. 4: 7) and Drnholec - Roviny (Cat. no. 19; Fig. 3: 4), which are flat on one side and have a depression on the outer side for an enamel inlay. ${ }^{13}$

A smaller part of pendants rank among less articulated forms (Břeclav - Hrudy: Cat. no. 3 - Fig. 2: 3; Drnholec - Roviny: Cat. no. 16, 21, 22 - Fig. 3: 1, 6, 7; Mikulov - U Aleje: Cat. no. 54 Fig. 5: 12 and Mušov - Na Pískách: Cat. no. 62 - Fig. 4: 7; possibly Břeclav - Nivečky: Cat. no. 7 - Fig. 2: 5 and Drnholec - Roviny: Cat. no. 17 - Fig. 3: 2), which are also known from LT B2-C1 cemeteries (cf. Waldhauser, Krásný 2006, 109-111; Čižmář, Jarůšková 2019, 386).
Another group consists of strongly profiled pendants, which are not known from cemeteries and which occur later - probably in stage LT C2 (cf. Čižmářr, Kolníková 2006, 264, Fig. 5: 13-20; Čižmář et al. 2010b, 661, Abb. 8: 13-20). Some strongly profiled pendants follow shapes common in the previous period but have a more pronounced profiled central globular part (Drnholec Roviny: Cat. no. 18 - Fig. 3: 3; Mušov - Na Pískách: Cat. no. 61 Fig. 4: 9). In some cases, the button at the bottom of the pendant is modelled into three parts (Drnholec - Roviny: Cat. no. 23 Fig. 3: 8), or decorated with an engraved triangle (MikulovU Aleje: Cat. no. 53 - Fig. 5: 11; cf. Němčice nad Hanou: Čižmářr, Kolníková 2006, Fig. 5: 14; Čižmář et al. 2010b, Abb. 8: 14; Bratislava - Devínska Kobyla: Budaj, Čambal 2016, 278, Fig. 5: 9). A group on its own (also from the point of view of their similar alloy composition) is that of pendants with a spherical, slightly flattened middle part and an eyelet in the shape of a rectangle with concave shorter side ${ }^{14}$ (Břeclav - Hrudy: Cat. no. 4 - Fig. 2: 4; Ladná - Padělky: Cat. no. 40 - Fig. 4: 5; Lanžhot - Horní Štěpnice: Cat. no. 41 - Fig. 4: 6).

Some forms of pendants are less usual: a specimen in the form of a bobbin ${ }^{15}$ (Drnholec - Roviny: Cat. no. 20 - Fig. 3: 5) with an unusually low lead content for pendants (9\%) or a strongly simplified pendant ending with a flat button (Mikulov - U Aleje: Cat. no. 55 - Fig. 5: 10). The pendant from Mušov - Na Pískách (Cat. no. 60; Fig. 4: 8) is unique; it ends with three bar-shaped knobs, though the affiliation of the pendant to a belt is uncertain. One of the pendants (Mikulov - Nad Valtickou silnicí: Cat. no. 51 - Fig. 5: 8) has a broken end part and its eyelet is in the form of a square frame with a circular opening.

Some of the pendants bear traces of heavy wear on the eyelet (Cat. 7, 18, 21, 60, 62; Fig. 2: 5, 3: 3, 6; 4: 7, 8), which probably led to the disruption of the eyelet and the loss of the pendant. However, there are also pendants with a partially preserved chainlet, in which the loss was probably caused by the opening of the wire links (Cat. no. 23, 53; Fig. 3: 8; 5: 11). The assemblage shows great variability in the shape of the pendants: not even at Drnholec - Roviny, where eight specimens were found, was there two identical shapes belonging to the same belt.

\subsection{Rings and wheels}

The studied assemblage from the Břeclav region includes five artefacts often referred to as amulets - one wheel with spokes (Hrušky - Tvrdonické podsedky: Cat. no. 29 - Fig. 4: 2) and four knobbed rings - Knotenringe (Břeclav - Přední čtvrtky: Cat. no. 8 Fig. 2: 8, Mikulov - Nad Valtickou silnicí: Cat. no. 48 - Fig. 5: 5, Mikulov - U Aleje: Cat. no. 52 - Fig. 5: 9, Sedlec - Za Čelovským: Cat. no. 67 - Fig. 5: 15). The form of another artefact from Břeclav - Lúbež (Cat. no. 6; Fig. 2: 7) resembles rings with knobs but does not fit with any known specimens. Knobbed rings and wheels with spokes have recently undergone comprehensive evaluation (Čižmářová 2014; Hlava 2015; Dębiec, Karwowski 2014; Dębiec, Karwowski 2016).

A fragment of a wheel with spokes (Hrušky - Tvrdonické podsedky: Fig. 4:2) can be placed according to the classification of Moravian finds in group I (simple articulated wheels with four or six spokes), which belongs to the most frequently represented types in Moravia (Čižmářová 2014, 655-666, Abb. 3: 1-14), also with respect to a very heterogeneous composition, without the addition of antimony (cf. Danielisová et al. 2020). A similar wheel from the Břeclav region from Bořetice - Díly za dvorem also has a circular cross-section of the wheel rim (Čižmářová 2014, 662, Abb. 3: 7). Although wheels with spokes already occur in LT B graves in the Middle Danube region and in Salzkammergut (Mannersdorf, Grab 13 - Ramsl 2011, 41, 133, Taf. 51: 7; Dürrnberg, 
Grab 55/2 and 96 - Penninger 1972, 91, Taf. 62: 4; Moosleitner et al. 1974, 63, Taf. 160: 10), they are not known in graves in Moravia and do not appear in greater numbers until LT C-D. In general, they are represented in Central Europe at 'medium-seized settlements', in agglomerations from LT C-D1 and abundantly at oppida (Danielisová et al. 2018a, 144; cf. Haselbach: Trebsche, Fichtl 2016b, 33, Abb. 14); however, even a later dating cannot be ruled out (especially in the case of presented finds without a context) (Hlava 2015, 271). In general, two geographical concentrations are apparent among Moravian finds: in central Moravia (especially in Němčice nad Hanou and surrounding sites and at Staré Hradisko) and in the Břeclav and Hodonín regions (cf. Čižmářová 2014, Abb. 1).

While knobbed rings (Knotenringe) are known from all over 'Celtic' Europe, their finds are concentrated in the Amber Route corridor (Dębiec, Karwowski 2016, 132). A total of four specimens occurred in the studied assemblage: Břeclav - Přední čtvrtky (Cat. no. 8; Fig. 2: 8), Mikulov - Nad Valtickou silnicí (Cat. no. 48; Fig. 5: 5), Mikulov - U Aleje (Cat. no. 52; Fig. 5: 9) and Sedlec - Za Čelovským (Cat. no. 67; Fig. 5: 15).

Finds from two neighbouring locations, Mikulov - U Aleje (Cat. no. 52; Fig. 5: 9) and Sedlec - Za Čelovským (Cat. no. 67; Fig. 5: 15) are similar in form and size and can be assigned to type IIB - the knots do not form groups on the outer surface, but are densely distributed in three rows (Dębiec, Karwowski 2016). A similar find from the region comes from Lednice - Podholmy (Goláňová, Kysela 2019, Fig. 2: 2). In the Břeclav region, type IIB of a similar size also comes from Břeclav, Podivín and nearby Bernhardsthal ${ }^{16}$ (Dębiec, Karwowski 2016, 140, Fig. 9: 92, 93, 95; 11: 123); other types (a larger specimen of type IIB) are also represented in the Břeclav region (Břeclav, Diváky, Hrušky: Dębiec, Karwowski 2016, 139-141, Fig. 7: 70; 9: 97; 13: 138, 141; Rakvice: Čižmář et al. 2009, Fig. 7: 11; Pavlov - Děvín: Goláňová, Navrátil 2017, 398, Fig. 4: 17).

Occurring most frequently among Knotenringe is type IIB, which - unlike other groups more abundantly represented at oppida - is also found in larger numbers at Němčice nad Hanou, from where we know Knotenringe in a size and shape similar to the finds from Břeclav (Dębiec, Karwowski 2016, 122, Fig. 10: 13). Among type IIB knobbed rings represented at oppida, there are no variants with elongated conical knobs of smaller dimensions, and this kind of Knotenringe is not present even in the Ptení hoard (cf. Čižmář 2002a; Hlava 2015). Thus, it seems that type IIB with elongated conical knobs is characteristic of LT C and has a strong representation in the Břeclav region.

A completely different type of Knotenringe is represented by a find from the Břeclav - Přední čtvrtky site (Cat. no. 8; Fig. 2: 8), where a ring with an oval cross-section with five large pea-shaped knobs was discovered (type IC after Dębiec, Karwowski 2016, 120). This type is relatively rare and the only parallel in Bohemia and Moravia (in terms of the number of knobs and their size relative to the ring) comes from Stradonice ${ }^{17}$ (Píč 1906, 64, Pl. XI: 4; Dębiec, Karwowski 2016, 120, 139, Fig. 19: 63).

The Knotenring from Mikulov - Nad Valtickou silnicí (Cat. no. 48; Fig. 5: 5) is one of the largest known specimens, and with an inner diameter of $4.4 \mathrm{~cm}$ it could also be worn as a bracelet (cf. Bujna 2005). Some Knotenringe are known in Moravia from inhumation graves (Brno - Brněnské Ivanovice: Čižmářová 2011, 77, 166, tab. 4: 11; Hrušky, Vyškov district: Čižmářová 2013, 126, 198, tab. 19: 7; Postoupky: Čižmářová 2017, 134, Tab. 45: 10); all of them are lacking an exact find context in the grave. ${ }^{18}$

A unique find is a ring from Břeclav - Lúbež with four large knobs decorated on the outside with grooves (Cat. no. 6; Fig. 2: 7).
In addition to finds in Slovenia and Croatia, ring artefacts of a similar shape (Vierknopf-Rädchen) are widespread, especially in Central Europe (cf. Schönfelder 2002, 251, Anm. 785). They are found in bronze and iron variants at the oppida of Staré Hradisko (Meduna 1961, 8, Taf. 7: 1, 2; Čižmář 2003a, Fig. 14: 3-5) and Stradonice (Píč 1906, Pl. XXXVI: 24,31) and at other hilltop sites in Slovakia. ${ }^{19}$ However, none of the aforementioned examples have knobs/buttons decorated with grooves, and the find from Břeclav - Lúbež also has a slenderer central ring of a semi-circular cross-section. While other finds appear to be part of a horse bit - 'Thracian types of bridles' (cf. Werner 1988, 81-101; Čižmář 2003a, 51) typical of the Padea-Panagjurski Kolonii group (Łuczkiewicz, Schönfelder 2008), in the case of the Břeclav find, the use of the ring in a horse's mouth is rather unlikely due to grooving - possible preparation for enamel decoration.

The studied assemblage of finds also includes four smooth undecorated rings from three sites: Brod nad Dyjí (Cat. no. 1; Fig. 2: 1), Drnholec - Roviny (two specimens - Cat. no. 24, 25; Fig. 3: 9-10), Hrušky - Tvrdonické podsedky (Cat. no. 30; Fig. 4:3). The rings are represented in roughly two sizes: with a diameter of $2.1-2.3 \mathrm{~cm}$ and $1.5-1.6 \mathrm{~cm}$. Two rings from Drnholec - Roviny may be related to numerous belt links from the site. The ring finds from the Břeclav region are comparable with other assemblages from La Tène sites, especially LT C-D (e.g., Vích 2017, 654; Danielisová et al. 2018a, 146, Fig. 14; Goláňová, Kysela 2019, 80, Fig. 2: 9-11; 3: 4-5, 7), even if their chronological classification in the La Tène period is not unquestionable.

\subsection{Coins}

A total of 18 coins from 11 sites are collected in the evaluated assemblage (Břeclav - Žleby, Horní Věstonice - Pod Transformátorem, Hrušky - Tvrdonické podsedky, Josefov - Pod Rozhranskem, Lanžhot - Padělky, Mikulov - Liščí hony, Pasohlávky - Drobné příděly, Př́tluky - U Hluboké vody, Rakvice Díly, Rakvice - Rybníčky, Tvrdonice - Pole od Týnecka). Although they were mostly found at sites with settlement from the La Tène period (Tab. 1), no other new artefacts are evaluated here from these sites (with the exception of Hrušky - Tvrdonické podsedky).

Until recently, small silver coins were almost unknown in the region, but their number is growing in the Břeclav region (cf. Kolníková, Koháček 2009; Smělý 2017a; Komoróczy et al. 2019b, 32, Fig. 22: 1-3). The largest group (seven silver coins) comes from Hrušky - Tvrdonické podsedky (Cat. no. 27, 31-36; Fig. 6: 2-8): without exception, these are small silver obols of the Roseldorf/ Němčice type, which are known in hundreds of pieces from the Němčice nad Hanou site and belong to LT C2 (Čižmář, Kolníková 2006, 275, Fig. 7: 14-27; Čižmář et al. 2010b, 670-671, Abb. 10: 9-22; Kolníková 2012, 33-55, Abb. 12-61; Militký 2018b, 11). These coins were also found in Lanžhot - Padělky (Cat. no. 42; Fig. 6: 11), Rakvice - Díly ${ }^{20}$ (Cat. no. 65; Fig. 6: 14), in Tvrdonice - Pole od Týnecka ${ }^{21}$ (Cat. no. 68; Fig. 6: 16) and at the settlement in Drnholec - Roviny (two coins; Komoróczy et al. 2019b, 32, Fig. 22: 2). An interesting coin found at the Rakvice - Rybníčky site (Cat. no. 66; Fig. 6: 15) corresponds in size to a Němčice-Roseldorf type obol. However, according to surface measurements using a hand-held XRF spectrometer, the coin has more than $70 \% \mathrm{Sn}$ and $26 \% \mathrm{~Pb}$ in the alloy. It is unlikely that the coin would be made as a period counterfeit of a small silver coin; it also does not match the size and weight of stater groups for use as the core of a conterfeit gold-plated coin (cf. Militký 2018a, 195).

The latest phase of the 'Boii' coinage (LT D1b-D2) is represented by silver obols of the Karlstein type discovered in Pasohlávky (Cat. no. 63; Fig. 6: 12) and Př́tluky (Cat. no. 64; 
Fig. 6: 13). Finds of these coins have been made at hilltop sites/ oppida in Lower Austria (Oberleiserberg), in west Slovakia (Bratislava) and in Bohemia (Stradonice), are also known from Moravia (mainly Staré Hradisko), though these Moravian finds still await a comprehensive evaluation (cf. Militký 2015, 84-88).

There are three gold coins in the assemblage: a $1 / 8$ stater of Athena Alkis comes from Břeclav - Žleby (Cat. no. 10; Fig. 6: 1), where part of a La Tène settlement was investigated (Dreslerová, Trampota 2016). Another $1 / 8$ stater together with $1 / 24$ stater was found in Josefov - Pod Rozhranskem in the Hodonín region (Cat. no. 37, 38; Fig. 6: 9-10), from where La Tène pottery and fragments of glass bracelets from LT C are known from surveys (Škojec 2000, 431, Abb. 20: 17-28). It is likely that $1 / 24$ staters were minted at centres in the Amber Route corridor, and they are also published in larger numbers from an unspecified location in the Břeclav region (Smělý 2017a, 507-508, Abb. 2: 2-7). Likewise, $1 / 8$ staters of the Athena Alkis type are especially characteristic of the Amber Route corridor in LT C (Militký 2018b, 284-286; cf. Němčice nad Hanou: Kolníková 2012, 16-18).

Two coins were probably not minted in the territory of Moravia: an imitation of a tetradrachm of Philip II of Macedon was found in Mikulov - Liščí hony (Cat. no. 43; Fig. 6: 18). The coin has a high share of lead and tin and probably originated in the Balkans. ${ }^{22}$ A later tetradrachm of the Kapos type found in Horní Věstonice (Cat. no. 26; Fig. 6: 17) was probably minted in LT D1 in the area of Pannonia (southwest Hungary), and the occurrence of these coins in Moravia is not unusual (Elschek, Kolníková 2014, 357; Militký 2015, 145).

\subsection{Glass}

A total of 5 glass artefacts were available in the studied assemblage: four fragments of bracelets and one fragment of a ring bead. The finds come from three locations in the cadastre of Mikulov: Mikulov - Na Mikulovsku (ring bead Haevernick group 23 - Cat. no. 45; Fig. 5: 1 and bracelet Haevernick group 11bCat. no. 44; Fig. 5: 2), Mikulov - Nad Valtickou silnicí (two bracelets - Haevernick group 6b/1?, group 8b - Cat. no. 46, 47; Fig. 5: 3-4), Mikulov - U Vodárny (bracelet Haevernick group 6b/2 - Cat. no. 56; Fig. 5: 14). The absence of glass artefacts from most of surveyed LT C-D sites is probably caused by the different perceptiveness of the finders in recognising glass fragments: three of the five glass artefacts come from a single finder.

Bracelets of Group 6b (cf. Venclová 1990, 120-122) are often represented in eastern Austria (Karwowski 2004, 22, 77, Abb. 25), southwest Slovakia (Březinová 2018, 27, map 5) and in central Moravia - in large numbers at Němčice nad Hanou (only a few at Staré Hradisko). They can be dated to the period from LT C1b to LT C2 (Venclová 2016, 47, 83), while variant 6b/1 probably comes from LT C1(b) (Venclová, Militký 2014, 394; Venclová 2016, 46).

Bracelets of Group 8b (variant 1 after Karwowski 2004) represent the second most common type in Němčice nad Hanou and can be chronologically placed in LT C1b-LT C2 (Venclová 2016, 49, 62). Finds from Lower Austria from the sites of Etzersdorf, Haselbach, and Roseldorf (Karwowski 2004, 26-27, 77) and those in the latest graves in the burial grounds in Maňa and Šurany - Nitrianský Hrádek (Březinová 2018, 28) also correspond to this time period. Compared to the types above, they occur more frequently in Staré Hradisko (Venclová 2016, 83). In the Břeclav region, this bracelet is represented by an intact specimen from a grave in Pasohlávky (Čižmářová 2019, 183, 278, Fig. 14, tab. 28: 8).

Bracelets of Group 11b are generally not very numerous (despite being well represented at Němčice nad Hanou) and their finds are concentrated in the Middle Danube region in LT C1b-C2 (Venclová 2016, 50; Březinová 2018, 28, map 8).
The bracelets of Group 13 - the most numerous in the Němčice agglomeration (Venclová 2016, 62) - are not present in the assemblage; nevertheless, the two bracelets of Group $6 \mathrm{~b}$ from the assemblage come from the group of bracelets, that is the most represented in the nearby agglomeration at Roseldorf (Holzer, Karwowski 2008, 167). However, the low number of finds and the characteristics of the assemblage from surveys do not permit further conclusions.

The cobalt blue ring bead with yellow whirl decoration from Mikulov - Na Mikulovsku belongs to Haevernick group 23. This group, the most common in Europe, is represented at Němčice nad Hanou by a single find and occurs abundantly at Staré Hradisko, which also corresponds to its chronological distribution (it appears in LT C2 and is also used in LT D1: Venclová $2016,56,86)$. It is also known from other sites in the Břeclav region (e.g., Břeclav - Pohansko: Čižmář 2001, 295, Fig. 1: 6).

The previous systematic investigations of the settlements in the region produced only rare finds of glass jewellery (cf. Strachotín: Čižmář 1987, 223, Fig. 4: 6). In the Břeclav region, the largest published collection of glass finds comes from excavations at the Early Mediaeval site of Břeclav - Pohansko (Čižmár 2001); however, the objects come only from Early Medieval contexts and were probably collected in the surrounding area only in this late stage (cf. collection of La Tène glass finds from the nearby Early Mediaeval stronghold in Mikulčice: Meduna 1997).

\section{The regional context of the finds}

The Břeclav region - especially in the Thaya River basin - is one of the best investigated regions in Moravia thanks to the construction of the Nové Mlýny dam and related rescue excavations in the 1970s and 1980s. Those revealed numerous sites from the La Tène period (cf. Jelínková, Kavánová 2002), but new finds gained by survey were identified with just two already excavated sites in Drnholec (see below) and Mušov (cf. Jelínková, Kavánová 2002, 277). Other studied artefacts come from the cadastral areas, where La Tène finds were discovered thanks to the dam excavations, but not in the same location (Brod nad Dyjí, Drnholec, Horní Věstonice, Mušov and Pasohlávky). ${ }^{23}$

The finds from Drnholec - Roviny come from an area 150-300 m far from a settlement Drnholec - Holenická pole, investigated by D. Jelínková in 1977-1981 during the construction of the Nové Mlýny reservoirs (eight sunken houses and several storage pits were uncovered here during the excavation: Jelínková, Kavánová 2002, 274-275, with refs.). Mapping of new finds from metal-detecting helped to define a new area of about 5 ha with evidence of activities in the La Tène period (Komoróczy et al. 2019b, 44, Fig. 26). The unusual concentration of belt elements (with a minimum of 13 specimens), and two burnt parts from one belt (Cat. no. 12, 13; Fig. 3: 13, 14) could have come from disturbed cremation graves. However, anomalies corresponding to sunken houses, which imply settlement activities, were discovered in the area during the geophysical survey (Komoróczy et al. 2019b, 22, Fig. 11, 14).

Completely unusual is the concentration of sites along the Thaya River (Fig. 1) - from the outlet of the Thaya from the Nové Mlýny reservoirs to Bernhardsthal, with traces of activities especially in LT C and possibly LT D1 (cf. Goláňová, Kysela 2019).

Finds from the cadastral area of Mikulov come from adjacent locations (Nad Valtickou silnicí, U Aleje, Na Mikulovsku, U Vodárny - Fig. 1: 15-18) and at a distance of about $1 \mathrm{~km}$ from them another find is known from the Sedlec - Za Čelovským site (Fig. 1: 24). La Tène settlement has been known from this part of the Mikulov territory since the 1930s, when H. Freising discovered a settlement at the 'Tirasfeld' site on the western slope of 'Mušlov' 
and in the 1970s, potsherds and allegedly a destroyed kiln were found in features disturbed by the extraction of sand (Meduna 1980b, 170-172, Taf. 49: 13-15; 50). Later, at the Na Rybníkách location, La Tène settlement was recorded on the entire hill to the left of the Mikulov - Lednice road (Meduna 1980b, 172).

The same concentration of sites with metal finds dated mainly to LT C-D is found in the cadastral areas of Břeclav and Hrušky (Břeclav - Hrudy, Břeclav - Líbivá, Břeclav - Lúbež, Břeclav Nivečky, Břeclav - Pohansko, Břeclav - Přední čtvrtky, Břeclav Žleby, Hrušky - Břeclavské Jochy, Hrušky - Čtvrtě, Hrušky - Tvrdonické podsedky: see above; Čižmář 2001; Čižmářová 2014, 662-663, Abb. 3: 5, 21, 32; Macháček 2001). At the same time, only one cemetery (from LT B) is known from those two cadastral areas - from Břeclav - Zvolence (Čižmářová 2019, 133-135, 239-240), and the only trace of activity in LT A identified to date is a bronze bird-head brooch found north of the Břeclav urban area (Čižmář 2012a, 228, Fig. 1: 5; Goláňová 2018, 210).

\section{Discussion and conclusion}

The presented assemblage is composed exclusively of artefacts from LT C-D, which also dominate other assemblages of La Tène finds obtained with the help of metal detectors (cf. Vích 2017; Danielisová et al. 2018a; Goláňová, Kysela 2019). The same spectrum of artefacts repeats in them, while artefacts from certain time periods (LT A, LT B1) are rarely represented, even though settlements with this dating are known in the Břeclav region (for LT A, cf. Goláňová 2018, 210-231, Fig. 6).

A more precise dating of activities at individual sites within LT C-D is difficult, ${ }^{24}$ as they have produced only a very limited number and range of finds (e.g., iron artefacts are missing completely). The chronology of the described artefacts is often not (with the exception of glass jewellery and coins) satisfactorily specific (due also to the absence of LT C2-D graves) or is known from a longer period of time (simple rings, wheels with spokes). However, we can state that most sites probably overlapped in time with the heyday of the agglomeration in Nermčice nad Hanou in LT C1-C2 (cf. Čižmář, Kolníková 2006; Čižmář et al. 2010b), where we find parallels for anthropomorphic figurines, belt components, glass bracelets and for some Knotenringe (Cat. no. 52, 67 - Fig. 5: 9, 15) and coins (Cat. no. 10, 27, 31-38, 42, 43, 65, 68 - Fig. 6: 1-11, 14, 16, 18). Artefacts found more often at oppida in LT (C2)-D1 (or in the $1^{\text {st }}$ century BC in general) are rather an exception in the presented assemblage (ring bead from Mikulov - Na Mikulovsku, coins from Horní Věstonice, Př́tluky and Pasohlávky: Cat. no. 45 - Fig. 5: 1; Cat. no. 26, 63, 64 - Fig. 6: 12, 13, 17).

An increase in the number of artefacts at a single site in LT C can be interpreted as an intensification of settlement (cf. in Bohemia at Žehun - Danielisová et al. 2018a, 161-162, Fig. 24), but from the perspective of the entire region, it is necessary to look for more factors contributing to the image of the repeated absence/minimal representation of artefacts from $\mathrm{LT} \mathrm{A-B1}$ in detector assemblages from lowland sites. In LT C, the number of artefacts made of copper alloys must have increased considerably, in the same way that in the Late Iron Age the number and spectrum of iron artefacts increased at oppida (cf. Drda, Rybová 1997, 93-100, Tab. 1). It is interesting that in the long-term studied and investigated Middle Thaya region before the use of metal detectors, Knotenringe, wheels with spokes, anthropomorphic figurines and elements from women's belts (except for those from the graves) were missing (cf. Meduna 1980b; Čižmář 2002b).

Some of the belts (Fig. 2: 2; 3: 7, 10, 13-14; 4: 11, 12; 5: 13) were exposed to heat and it cannot be ruled out that they come from cremation graves (cf. Hulín - U Isidorka: Tajer 2009).
However, most of the presented artefacts have parallels in the settlements, at central sites in the Amber Route corridor (Němčice nad Hanou, Roseldorf, Nowa Cerekwia) or in their immediate vicinity (buffer of sites around Němčice nad Hanou cf. below). Anthropomorphic figurines otherwise occurred only rarely in Moravia outside the broader area of Němčice and Břeclav. Even coin finds from the studied assemblage prove the affiliation of south Moravia to a specific circle of the eastern part of the Middle Danube region with a local identity (Venclová, Militký 2014). Finds of semi-finished/miscasts of belt elements from two sites (Hrušky - Tvrdonické podsedky, Bernhardsthal) and traces of copper alloy processing at other places in the region (Goláňová, Kysela 2019, 85) document that metal casting was not centralised at a single large agglomeration.

Also coming from the Brreclav region (from the area at the confluence of the Thaya and Morava rivers) is a semi-finished product for coin minting - an unstruck gold flan/blank weighing 1/8 of a stater (Kolníková, Koháček 2009, 274, Tab. 1, Fig. 1: 4). Besides agglomerations (like Němčice nad Hanou and Roseldorf for LT C and oppida for LT C2-D; cf. Militký 2018b, 284-290) coin minting in Central Europe during the La Tène period is also considered for regional centres ('medium-sized settlements', a category between agglomerations and rural settlements) - e.g., Žehuň with almost 150 coins and two gold ingots (Danielisová et al. 2018a, 167; Militký 2018a). ${ }^{25}$ The number of coins from other settlements in Bohemia is low (mostly single-digit numbers, dozens in exceptional cases: Militký 2018b, 309-314, tab. 34) and assemblages published to date from the Břeclav region and the surrounding area (Fig. 6) do not exceed these numbers $^{26}$ (cf. Kolníková, Koháček 2009; Komoróczy et al. 2019b, 32, Fig. 22: 1-3). The only exception is an assemblage of 28 coins from an unspecified site in the Břeclav region allegedly forming only a small share of the coins found at a previously unpublished place where coin production is expected (Smělý 2017a).

Sites located a short distance from each other (Fig. 1 - eastern part of the Mikulov, Břeclav/Hrušky cadastral area, a band on both banks of the Thaya between Př́tluky and Břeclav - Pohansko) form clusters of sites with a similar spectrum of metal finds dated mainly to LT C-D1. In the Břeclav region, however, there is still no reliably localised regional centre (cf. an unspecified site for the find of a large number of coins in the vicinity of Břeclav - Smělý 2017a) that would far exceed average settlements in terms of the number of finds. And yet, the presented assemblage (and other finds from the region: Goláňová, Navrátil 2017; Goláňová, Kysela 2019) clearly shows that while some sites in the Břeclav region have a lower quantity, the quality of the metal finds is comparable to regional centres (such as Žehuň).

The question remains as to what extent the clusters of finds from neighbouring locations in some of the cadastres (Mikulov, Břeclav/Hrušky) from LT C-D represent traces of scattered settlement (e.g., individual isolated homesteads spaced several dozen to hundreds of metres apart) or testify to the concentration of occupation around a central settlement ${ }^{27}$ that remains as yet unidentified. The number of finds from distinct sites is consistent with an image known thus far for sites in the immediate vicinity of Němčice nad Hanou (within a radius of about $12 \mathrm{~km}$ : Bezměrov, Biskupice, Hrubčice, Klenovice na Hané, Lešany, Medlovice, Měrovice, Polkovice, Těšice), at which artefacts similar to those in the Němčice agglomeration occur, including gold coins, albeit in far fewer numbers (cf. Čižmář et al. 2008; 2009; 2010a; 2011; Kolníková 2012, 69-72; cf. Čižmářová 2014, 662-664).

In southwest Slovakia, a concentration of La Tène settlement is known in Záhorie in the cadastral area of Zohor, where a site in the Piesky location with La Tène features was investigated 
over an area of 5 ha (with an estimated total occupied area of 15-20 ha) as were another 14 La Tène sites ${ }^{28}$ in the surrounding area of roughly $4 \times 5 \mathrm{~km}$ (Elschek, Kolníková 2014). The authors regard the Zohor - Piesky site as a supraregional centre (Elschek, Kolníková 2014,355), despite the lack of any traces of specialised production or coin minting. ${ }^{29}$ (In the context of large centres) modest coin finds (eight pieces) from Zohor - Piesky prove with the presence of Roseldorf/Němčice type obols ties to coinage in the Amber Route corridor at least for LT C (cf. Militký 2018b, 284-290; Smělý 2017b). The chain-belt links from Zohor - Piesky are of the same type with a central globular element that are abundant in the Břeclav region (see above).

A similar situation (concerning the cluster of settlements) was recently described for LT C2-D1 in Straubing, where a concentration of occupation (linked to rivers, especially the Danube) around an assumed large settlement with production and trade activities was found at the Ostenfeld site. In the 'hinterland' of Ostenfeld is another settlement agglomeration (Lerchenhaid, with representative buildings and craft production) and agricultural settlements located on loess; however, even at these settlements, archaeological excavations brought evidence of craft activities associated with metal processing. The sites are concentrated within a radius of about $5 \mathrm{~km}$ from Ostenfeld, followed by (despite fertile soil) a belt without settlement ${ }^{30}$ (Tappert 2019, 357-363, Abb. 5-6).

The role of these concentrations of sites in the settlement hierarchy of communities in the La Tène period in Moravia is not clear (cf. Goláňová, Kysela 2019, 83-86). They could belong to buffer of settlements around central sites ${ }^{31}$ or 'agglomerations' in another sense: composed of a grouping of settlements ('mega-municipalities' or 'habitat groupé'32 - cf. Deberge et al. 2019, 180-189, Fig. 3-7).

Future research will need to focus not only on centres of the Němčice/Roseldorf type (or medium-sized settlements of the Žehuň type), but also on clusters of surrounding sites and address issues concerning relations between settlements and the centre (e.g., subsistence, product distribution - cf. Kohler-Schneider et al. 2015, 536). Is the prosperity of the centre reflected in the surrounding settlements - or was it the other way around? What could this mean in terms of the organisation of society and its identity? Are there clusters of settlements with similar characteristics without one of them playing a central role? Some of these questions can be answered only by field excavations combined with multi-proxy analyses, but detector finds themselves form a new layer of information about La Tène settlement of the Břeclav region complementing (and sometimes changing) the view of this period in Moravia.

\section{Notes}

1 The results of surface measurements are influenced by the calibration of the actual device, the measurement mode used (in this case individual detection of sulphur, silicon, phosphorus or even mercury in certain artefacts), as well as by surface geometry, measurement place selection or contamination with soil impurities, which is most often manifested in an increased content of iron, titanium, chromium, vanadium or zirconium. The long-term deposition of artefacts in the soil has a fundamental effect, especially the effect of corrosion processes, in case of copper alloys artefacts ususally result, among other things, in the overstatement of the surface content of tin and lead at the expense of copper. In the case of coins, the possibility of intentional surface treatment should be considered in addition to natural influences.
2 Elemental composition analysis parameters on an ElvaX Pro benchtop spectrometer: Ag X-ray tube, Cu mode, measuring time $120 \mathrm{~s}$, accelerating voltage $45 \mathrm{kV}$; collimator $4 \mathrm{~mm}$; individual evaluation of spectra in ElvaX software.

3 Given the total number of artefacts in the analysis and the number of descriptors (three elements) that are interdependent, further multidimensional analysis would not provide greater insight into structures in the data.

4 A very similar composition (Cu 71.34; Pb 25.07; Sn 3.19; Sb 0.094; Bi 0.179; Ag 0.019; Co 0.068; Ni 0.048; measured recently by M. Kmošek) was also found by bulk analysis of the metal core of the figurine from the Lednice - Podholmy site (Goláňová, Kysela 2019, 72, Fig. 2: 1; 4).

5 From the vicinity of Němčice nad Hanou, the only other figurine published to date is from Biskupice, Prostějov district (Čižmář 2012b, 154, Fig. 4: 3), which, however, does not fit with either the high level of craftsmanship or the posture of the figurine among other schematic representations of the human body. Human figurines, unlike those of animals (cf. Čižmář 2012b, 160, 163, 165, Fig. 13: 1, 3, 13, 14), are not yet known from surrounding settlements.

6 An unpublished pendant from the Břeclav - Žleby settlement has a similar form (bucket with button-shaped knobs).

7 The find of a basket-shaped pendant in the hoard from Ptení (Čižmář 2002a, 208, 210), which was assigned to this category only on the basis of a preserved description, was recently challenged by M. Hlava $(2015,272)$ on the basis of newly found images in the archive.

8 Perhaps also belonging among vessel-shaped pendants with a button-like terminal is a find from the Udrina fortified settlement in the Bánovce nad Bebravou district of Slovakia (Pieta 2018, Abb. 13:2 - bottom left), but it is not clear from the photo whether the pendant is hollow (solid vase-shaped pendants are regarded as belt elements).

9 In Central Europe, an elongated 'situla-shaped' hollow bronze pendant with an origin outside Europe and dating to the mid- $5^{\text {th }}$ century BC is known from Straubing. The pendant has a button-shaped bottom end decorated with triangles (Tappert, Mielke 1998), but is too distant (both in time and place of origin) for inspiring the Central European pendants. A situla-shaped pendant with the same method of suspension comes from Prozor, Croatia (Teßmann 2007, 690, Abb. 21: 2-3).

10 Dolní Bojanovice - Vsisko (Čižmářová 2017, 81, tab. 2: 5, 10, 11), Křepice, Břeclav district (Čižmářová 2019, 163, 266, Tab. 20: 1), Charváty (Čižmářová 2017, 143-144, 255, tab. 50: 2-3, 5-6), Hulín (Tajer 2009), Ponětovice (Čižmářová 2011, tab. 47: 7, 8), Střelice - Padělky (Čižmářová 2011, 152, tab. 51: 5-7).

11 This idea is also confirmed by the results of measurements of the metal composition.

12 Corresponding to this link in terms of size is another link with a central annular part found in Drnholec - Roviny (Komoróczy et al. 2019b, Fig. 16: 14).

13 A flat pendant with a depression for enamel also comes from Nejdek in the Břeclav region (Čižmařova 2019, 175, 273, Tab. 25: 6) and from Ponětovice in the Brno region, grave 2 and 34 (Čižmařova 2011, 133, 145, 209, 221, tab. 35: 16; 47: 4).

14 A similar pendant was found at the Čebovce - Zámok site (Čambal et al. 2017, Abb. 4: 41).

15 Analogical finds are known from the sites of Chornice and Lázy (Vích 2017, 638, Fig. 8: 4; 7: 13), Žehuň (Danielisová et al. 2018a, Fig. 12: 70, 71) and Stradonice (Píč 1906, Pl. XX: 15, $18,27)$. 
16 Of a similar size is the previously published toothed wheel, perhaps originally with spokes, from Drnholec - Holenická pole/Roviny (Komoróczy et al. 2019b, Fig. 16: 24).

17 However, the ring from Břeclav - Přední čtvrtky is smaller.

18 For two of them their use as a bracelet could be considered on the basis of an internal diameter exceeding $6 \mathrm{~cm}$ (Brno-Brněnské Ivanovice; Hrušky, Vyškov district). The ring from Postoupky (Čižmářová 2017, 134, Tab. 45: 10) with an inner diameter of $2.8 \mathrm{~cm}$ must have had a different function.

19 The iron specimen comes from the Udiča site (Pieta 2008, Fig. 113: 12), the bronze specimens from Prašník (Kolník 1999, 193-195) and Jánovce - Machalovce (Soják, Fecko 2019, 455, Fig. 2).

20 A La Tène settlement was investigated at this location ( $\mathrm{Me}^{-}$ duna 1980b, 264, Horálková 1989; Klanicová 1998, 171).

21 In Tvrdonice - Pole od Týnecka, there are traces of settlement with finds of pottery, a fragment of a glass bracelet made of blue glass (Klanicová 2000,390) and crucibles (Čižmář 2003b, 247, Fig. 2: 5, 8).

22 One such coin is also known from Němčice nad Hanou (Kolníková 2012, 55, 57, Abb. 62: 925; 85: 925).

23 The Pod silnicí location in Brod nad Dyjí is situated only a few hundred metres from the Krátká loučka/Hartinger location, where a part of a settlement with sunken features dated to LT C (Jelínková, Kavánová 2002, 273), was investigated.

24 The situation from Drnholec - Roviny, from where only parts of belts belonging to LT C are presented in this study, reveals the pitfalls of dating sites only on the basis of selected detector finds (Cat. no. 11-25, Fig. 3). However, an archaeological excavation in the years 1977-1981 determined and produced evidence of settlement from LT D (Čižmář 2002b, 252; Jelínková, Kavánová 2002, 274-275).

25 For the time being, the Chornice 2c/Lázy 3c site (on both banks of a watercourse) in Malá Haná on the Bohemian-Moravian border (Vích 2017) can be considered a more modest 'central settlement', with (in the region unusual) concentration of ceramic, metal and glass artefacts, including an anthropomorphic figurine, a mirror fragment, coins and coin metal. There are another eight sites (from LT B2-D1) with a smaller number of finds within a radius of up to $3 \mathrm{~km}$. Coins from this area rank among those struck in Moravia during the La Tène period (Militký 2018b, 313).

26 Up to twenty coins, though more often single-digit numbers of finds, are also known from settlements in the 'buffer' zone around Němčice nad Hanou (Kolníková 2012, 69-73).

27 Cf. Žehuň with a maximum area of 12.5 ha (Danielisová et al. 2018a, 130); Haselbach - minimum area of occupied area 6.6 ha (Trebsche, Fichtl 2016b, 22).

28 Three of these sites together form a larger settlement with an area of at least 2 ha (Elschek, Kolníková 2014).

29 Traces of coin minting are documented at the Šaštín - Stráže settlement in Slovakia, a mere $20 \mathrm{~km}$ from Břeclav, by fragments of a ceramic casting tablets with traces of silver for producing coin blanks (Ščasnár et al. 1984, 130, Fig. 2: 1-3).

30 This settlement-free area is also respected by Viereckschanze (rectangular enclosures/homesteads), otherwise located densely in the lowlands around the Danube (Tappert 2019, 363, Abb. 6).

31 These centres are typically labelled as 'production and distribution centres', or a 'Němčice-Roseldorf type centre' (Salač 2014), 'medium-sized settlements/Mittlere Zentren' and 'large settlements/Großsiedlungen/Große Zentren' (Trebsche 2014; 2019) or (particularly in France) agglomerations (cf. Fichtl et al. 2019) with concentrations of population, buildings and craft activities to a varying extent.
32 The term 'habitat groupé' is used for the 'Aulnat' open agglomeration of 150 ha (Brezet, Gandaillat, La Grande Borne) in agriculturally suitable terrain with traces of specialised production, trade and long-distance contacts in certain areas, including settlements and graves units (Deberge et al. 2019).

\section{Acknowledgments}

The study was created as part of Czech Science Foundation Project GA20-11070S (Protohistoric Communities of the 'Marcomannic' Settlement Zone in the Middle Danube Region - Structure and Dynamic on the Basis of Digital Modelling), as an output of a project of the Regional Cooperation Between Regions and the Institutes of the Czech Academy of Sciences programmeR300012001 (Implementation of Civic Engagement in the Protection and Knowledge of the Archaeological Heritage of the South Moravian Region), and within the programme framework Strategy AV21, research programme 'Europe and state: between barbarism and civilisation', project 'Pure and barbarian metals', as well as thanks to the Grant Agency of Masaryk University (MUNI/A/0839/2019).

\section{References}

Allerbauer, S., Jedlicka, F. 2001: KG Bernhardstahl, MG Bernhardstahl, VB Mistelbach. Fundberichte aus Österreich 39/2000, 614-616.

Bland, R. 2005: A pragmatic approach to the problem of portable antiquities: the experience of England and Wales. Antiquity 79(304), 440-447.

Březinová, G. 2018: Šperk zo skla a sapropelitu u Keltov na Slovensku. Archaeologica Slovaca Monographiae, Studia XXX. Nitra: Archeologický ústav SAV v Nitre.

Budaj, M., Čambal, R. 2016: Laténske nálezy z Bratislavy - Devínskej Kobyly. Numismatický sborník 30(2), 273-283.

Bujna, J. 2005: Kruhový šperk z laténskych ženských hrobov na Slovensku. Nitra: Filozofická fakulta Univerzity Konštantína Filozofa, Archeologický ústav SAV v Nitre.

Bujna, J. 2011: Opasky ženského odevu z doby laténskej. Nitra: Filozofická fakulta Univerzity Konštantína Filozofa, Archeologický ústav SAV v Nitre.

Čambal, R. 2008: Osídlenie okresov Bratislava, Senec a Pezinok v dobe laténskej. In: P. Pospechová, P. Wittgrúber (zost.): Carnuntum-Gerulata. Germánske osídlenie pri Dunaji v priestore Bratislavskej brány ako širšie hospodárske a sociálne zázemie Carnunta a Gerulaty. Pezinok: Mestské muzeum v Pezinku, 101-117.

Čambal, R. 2011: Sídliskové objekty zo strednej a neskorej doby laténskej v Slovenskom Grobe. Zborník Slovenského národného múzea CV, Archeológia 21, 83-114.

Čambal, R. 2015: Datovanie hradiska Pohanská pri Plaveckom Podhradí v dobe laténskej z pohl'adu archeologických a numizmatických nálezov. Numizmatika 25, 41-44.

Čambal, R., Kovár, B., Budaj, M. 2017: Neue hallstattzeitliche und latènezeitliche Funde aus Čebovce, Fundlage Zámok (Bez. Vel'ký Krtíš). In: J. Kysela, A. Danielisová, J. Militký (eds.): Stories that made the Iron Age. Studies in Iron Age Archaeology dedicated to Natalie Venclová. Praha: Institute of Archaeology of the Czech Academy of Sciences, v. v. i., Charles University, Faculty of Arts, 433-447.

Chakrabarti, D. J., Laughlin, D. E. 1984: The Cu-Pb (Copper-Lead) system. Bulletin of Alloy Phase Diagrams 5, 503-510.

Čižmář, I., Jarůšková, Z. 2019: Nález keltského řetězového opasku z Kunštátska (okr. Blansko). Studia Historica Nitriensia 23, Supplementum, Sedem kruhov Josefa Bujnu. Nitra: Univerzita Konštantína Filozofa v Nitre, 373-393. 
Čižmář, I., Mikulková, B., Kmošek, M., Chovanec, M., Kala, J. 2020: Dva mimořádné hroby z laténského pohřebiště v Rousínově. Přrehled výzkumů 61(1), 105-122.

Čižmář, M. 1987: Laténské sídliště ze Strachotína, okr. Břeclav. Památky archeologické LXXVIII, 205-230.

Čižmář, M. 2001: K laténskému osídlení Pohanska u Břeclavi. In: V. Podborský (ed.): 50 let archeologických výzkumů Masarykovy univerzity na Znojemsku. Brno: Masarykova univerzita, 295-299.

Čižmář, M. 2002a: Laténský depot ze Ptení. K poznání kontaktů našeho území s jihem. Památky archeologické XCIII, 194-225.

Čižmář, M. 2002b: Vývoj laténského osídlení v oblasti pod Pavlovskými vrchy. In: S. Stuchlík (ed.): Oblast vodního díla Nové Mlýny od pravěku do středověku. Spisy Archeologického ústavu AV ČR Brno 20. Brno: Archeologický ústav AV ČR, Brno, 249-271.

Čižmář, M. 2003a: Laténské sídliště v Bořitově. Pravěk, Supplementum 10. Brno: Ústav archeologické památkové péče.

Čižmář, M. 2003b: Nálezy tyglíků na laténských nížinných sídlištích na Moravě. Pravěk Nová řada 12/2002, 243-255.

Čižmářr, M. 2012a: Frühlatènezeitliche figürliche Fibeln aus Mähren. In: Ch. Pare (Hrsg.): Kunst und Kommunikation. Zentralisierungsprozesse in Gesellschaften des europäischen Barbarikums im 1. Jahrtausend v. Chr. RGZM, Tagungen 15. Mainz: Verlag des Römisch-Germanischen Zentralmuseums, 223-231.

Čižmářr, M. 2012b: Nálezy drobné lidské a zvírrecí plastiky z Moravy. In: G. Březinová, V. Varsik (eds.): Archeológia na prahu histórie. K životnému jubileu Karola Pietu. Archaeologica Slovaca Monographiae Communicationes XIV. Nitra: Archeologický ústav SAV v Nitre, 145-173.

Čižmář, M., Čižmářová, J., Kejzlar, M. 2011: Detektorová prospekce archeologických lokalit na Moravě v roce 2010. Přehled výzkumů 52(2), 86-95.

Čižmář, M., Čižmářová, J., Kejzlar, M., Kolníková, E. 2008: Detektorová prospekce lokalit $\mathrm{z}$ doby laténské na Moravě. Přehled výzkumů 49, 125-131.

Čižmář, M., Čižmářová, J., Kejzlar, M., Kolníková, E. 2009: Detektorová prospekce archeologických lokalit na Moravě v roce 2008. Přehled výzkumu 50, 139-152.

Čižmář, M., Čižmářová, J., Kejzlar, M., Kolníková, E. 2010a: Detektorová prospekce archeologických lokalit na Moravě v roce 2009. Přrehled výzkumů 51, 125-137.

Čižmář, M., Kolníková, E. 2006: Němčice - obchodní a industriální centrum doby laténské na Moravě. Archeologické rozhledy LVIII(2), 261-283.

Čižmář, M., Kolníková, E., Noeske, H.-Ch. 2010b: Němčice-Víceměrice - ein neues Handels- und Industriezentrum der Latènezeit in Mähren. Germania 86/2008, 655-700.

Čižmář, M., Salaš, M. 2009: Nové hradiště v Moravské bráně. Archeologické rozhledy LXI(1), 63-76.

Čižmářová, H. 2014: Ein Beitrag zu neuen Funden latènezeitlicher gegliederter Rädchen in Mähren. In: J. Čižmářová, N. Venclová, G. Březinová (eds.): Moravské křrižovatky. Střrední Podunaji mezi pravěkem a historí. Brno: Moravské zemské muzeum, 655-665.

Čižmářová, H. 2019: Maskovité korálky na Moravě. Studia Historica Nitriensia 23, Supplementum, Sedem kruhov Josefa Bujnu. Nitra: Univerzita Konštantína Filozofa v Nitre, 21-32.

Čižmářová, J. 2004: Encyklopedie Keltu na Moravě a ve Slezsku. Praha: Nakladatelství Libri.

Čižmářová, J. 2005: Keltské pohřebiště v Brně-Maloměřicích. Pravěk, Supplementum 14. Brno: Ústav archeologické památkové péče Brno.

Čižmářová, J. 2009: Keltská pohřebiště z Holubic a Křenovic. Pravěk, Supplementum 19. Brno: Ústav archeologické památkové péče Brno.

Čižmářová, J. 2011: Keltská pohřebiště na Moravě. Okresy Brno-město a Brno-venkov. Brno: Moravské zemské muzeum.
Čižmářová, J. 2013: Keltská pohřebiště na Moravě. Okresy Blansko a Vyškov. Brno: Moravské zemské muzeum.

Čižmářová, J. 2017: Keltská pohřebiště na Moravě. Okresy Hodonín, Kroměř Zlín. Brno: Moravské zemské muzeum.

Čižmářová, J. 2019: Keltská pohřebiště na Moravě. Okresy Břeclav a Znojmo. Brno: Moravské zemské muzeum.

Danielisová, A., Bursák, D., Strnad, L., Trubač, J., Čižmářová, H., Daněček, D., Smíšek, K. 2020: Rituals, Hoards or Travellers? Archaeometry of the Iron Age Bronze Wheel Amulets. Interdisciplinaria Archaeologica XI(1), 33-45.

Danielisová, A., Kysela, J., Mangel, T., Kyselý, R., Militký, J. 2018a: Iron Age site in Žehuň, Central Bohemia. An open settlement with central functions. Památky archeologické CIX, 127-178.

Danielisová, A., Strnad, L., Mihaljevič, M. 2018b: Circulation Patterns of Copper-Based Alloys in the Late Iron Age Oppidum of Třísov in Central Europe. Metalla 24(1), 5-18.

Deberge, Y., Kurzaj, M.-C., Lauranson, R. 2019: Les agglomérations ouvertes de la fin de l'âge du Fer en territoires arverne et vellave (nord-est du Massif central). In: S. Fichtl, P. Barral, G. Pierrevelcin, M. Schönfelder (dir.): Les agglomérations ouvertes de l'Europe celtique (III $I^{e} I^{e r}$ S. av. J.-C.). Table ronde internationale. Glux-en-Glenne, 28, 29 et 30 octobre 2015. Mémoires d'Archéologie du Grand Est 4. Strasbourg: Avage, 175-212.

Dębiec, M., Karwowski, M. 2014: Celtic Knotenringe from Staré Hradisko. In: J. Čižmářová, N. Venclová, G. Březinová (eds.): Moravské křižovatky. Střední Podunají mezi pravěkem a historí. Brno: Moravské zemské muzeum, 667-680.

Dębiec, M., Karwowski, M. 2016: A Typological Study of the La Tène Knotenringe in the Territory of the Boii. In: M. Karwowski, P. C. Ramsl (Eds.): Boii - Taurisci. Proceedings of the International Semina, Oberleis-Klement, June 14th-15th, 2012. Mitteilungen der Prähistorischen Kommission 85. Wien: Verlag der Österreichische Akademie der Wissenschaften, 115-146.

Drda, P., Rybová, A. 1997: Keltská oppida v centru Boiohaema. Památky archeologické LXXXVIII, 65-123.

Dreslerová, G., Trampota, F. 2016: Břeclav (okr. Břeclav). Přehled výzkumu 57(1), 237.

Elschek, K., Kolníková, E. 2014: Beitrag zur Datierung der latènezeitlichen Zentralsiedlung von Zohor in der Westslowakei. Kleinfunde, keltische und frührömische Münzen. In: J. Čižmářová, N. Venclová, G. Březinová (eds.): Moravské křrižovatky. Střední Podunají mezi pravěkem a historií. Brno: Moravské zemské muzeum, 353-375.

Faudino, V., Ferrero, L., Giaretti, M., Venturino Gambari, M. 2014: Celti et Liguri. Rapporti tra la cultura di Golasecca et la Liguria interna nella prima Età del ferro. In: P. Barral, J.-P. Guillaumet, M.-J. Roulière-Lambert, M. Saracino, D. Vitali (éd.): Les Celtes et le Nord de l'Italie. Premier et Second Âges du fer. Actes du XXXVIe colloque international de l'AFEAF Vérone 17-20 mai 2012. $36^{\mathrm{e}}$ supplément à la Revue Archéologique de l'Est. Dijon: Société archéologique de l'Est, 125-143.

Ficht1, S., Barral, P., Pierrevelcin, G., Schönfelder, M. 2019: Les agglomérations ouvertes de l'Europe celtique (III ${ }^{e} \mathrm{I}^{e r}$ s. av. J.-C.). Table ronde internationale. Glux-en-Glenne, 28, 29 et 30 octobre 2015. Mémoires d'Archéologie du Grand Est 4. Strasbourg: Avage.

Frána, J., Jiráň, L., Moucha, V., Sankot, P. 1997: Artifacts of copper and copper alloys in prehistoric Bohemia from the viewpoint of analyses of element composition II. Památky archeologické, Supplementum 8. Praha: Archeologický ústav AV ČR, Praha.

Garrow, D., Gosden, Ch. 2012: Technologies of Enchantment? Exploring Celtic Art: 400 BC to AD 100. Oxford: Oxford University Press.

Goláňová, P. 2018: The Early La Tène Period in Moravia. Studien zur Archäologie Europas 32. Bonn: Habelt Verlag. 
Goláňová, P., Kysela, J. 2019: What can the dwarfs tell? On settlements and anthropomorphic statuary in La Tène Southern Moravia. Studia Historica Nitriensia 23, Supplementum, Sedem kruhov Josefa Bujnu. Nitra: Univerzita Konštantína Filozofa v Nitre, 71-92.

Goláňová, P., Navrátil, A. 2017: The Pálava hills during the La Tène Period. In: J. Kysela, A. Danielisová, J. Militký (eds.): Stories that made the Iron Age. Studies in Iron Age Archaeology dedicated to Natalie Venclová. Praha: Institute of Archaeology of the Czech Academy of Sciences, v. v. i., Charles University, Faculty of Arts, 393-409.

Hlava, M. 2015: Laténský depot z Ptení (okr. Prostějov): nová fakta. Památky archeologické CVI, 247-290.

Holzer, V., Karwowski, M. 2008: Glasfunde der Grabungen 2001 bis 2007 aus der keltischen Zentralsiedlung in Roseldorf, Niederösterreich. Fundberichte aus Österreich 46/2007, 153-172.

Horálková, P. 1989: Rettungsgrabung in Rakvice. Přehled výzkumů 1986, 94.

Hundt, H. J. 1935: Spätlatèneimport in Grabfunden von Neu-Plötzin, Mark Brandenburg. Germania 19, 239-248.

Jelínková, D., Kavánová, B. 2002: Soupis nalezišt z doby laténské. In: S. Stuchlík (ed.): Oblast vodního díla Nové Mlýny od pravěku do středověku. Spisy Archeologického ústavu AV ČR Brno 20. Brno: Archeologický ústav AV ČR, Brno, 273-290.

Karl, R. 2019: Authorities and subjects? The legal framework for public participation in Austrian archaeology. European Journal of Post-Classical Archaeologies 9, 219-256.

Karwowski, M. 2004: Latènezeitlicher Glasringschmuck aus Ostösterreich. Mitteilungen der Prähistorischen Kommission 55. Wien: Österreichische Akademie der Wissenschaften, Philosophisch-historische Klasse.

Klanicová, E. 1998: Archeologické lokality na katastru Rakvic. Jižní Morava 34, sv. 37, 167-178.

Klanicová, E. 2000: Archäologische Fundstätten und Funde im „Hinterland“ des Burgwalls von Mikulčice III (Katastralgebiete Kostice, Lanžhot, Tvrdonice, Týnec). In: L. Poláček (Hrsg.): Studien zum Burgwall von Mikulčice. Band IV. Spisy Archeologického ústavu AV ČR Brno 18. Brno: Archäologisches Institut der Akademie der Wissenschaften der Tschechischen Republik Brno, 363-403.

Kmošek, M. 2019: Měd’ a její slitiny jako surovina kovové industrie v pravěku a protohistorii na území jižní Moravy [online]. Rkp. diplomové práce. Masarykova univerzita. Filozofická fakulta. Ústav archeologie a muzeologie. Uloženo: Archiv závěrečných prací Masarykovy univerzity [cit. 2020-05-18]. Dostupné z: https://is.muni.cz/th/ml8ni/.

Kohler-Schneider, M., Caneppele, A., Heiss, A. G. 2015: Land use, economy and cult in late Iron Age ritual centres: an archaeobotanical study of the La Tène site at Sandberg-Roseldorf, Lower Austria. Vegetation History and Archaeobotany 24, 517-540.

Kolník, T. 1999: Unikátne nálezy z Prašníka. Študijné zvesti Archeologického ústavu Slovenskej akadémie vied 33, 1999, 193-196.

Kolníková, E. 2012: Němčice - ein Macht-, Industrie- und Handelszentrum der Latènezeit in Mähren und Siedlungen am ihren Rande. Kommentierter Fundkatalog - Münzen. Spisy Archeologického ústavu AV ČR Brno 43. Brno: Archeologický ústav AV ČR, Brno, v. v. i.

Kolníková, E., Koháček, R. 2009: Nové keltské mince z južnej Moravy. Numismatický sborník 24, 309-316.

Komoróczy, B., Vlach, M., Hložek, M. 2014: Detektorový nález římsko-provinciálního prolamovaného kování z Pavlova, Jihomoravský kraj. In: J. Čižmářová, N. Venclová, G. Březinová (eds.): Moravské křrǐ̌ovatky. Střední Podunají mezi pravěkem a historiú. Brno: Moravské zemské muzeum, 767-784.

Komoróczy, B., Vlach, M., Zelíková, M. 2017: Dokumentace, publikace a interpretace detektorových nálezů na příkladu spon typu Jobst 4F. In: E. Droberjar, B. Komoróczy (eds.): Římské a germánské spony ve střední Evropě (Archeologie barbarů 2012). Spisy Archeologického ústavu AV ČR Brno 53. Brno: Archeologický ústav AV ČR, Brno, 31-61.

Komoróczy, B., Vlach, M., Zelíková, M., Sedláček, J., Růžičková, P. 2019b: Revize stavu archeologických komponent v trati Drnholec „Holenická pole“ pomocí prospekčních a málo známých invazivních výzkumných metod. Přehled výzkumů 60 (2), 9-56.

Komoróczy, B., Zelíková, M., Lečbychová, O., Fedor, P., Kynclová, P. et al. 2019a: Společnými silami za poznáním společného archeologického dědictví Jihomoravského kraje. Brno: Archeologický ústav AV ČR, Brno, Jihomoravský kraj.

Kuča, M., Ženožičková, I. 2017: Jamolice (okr. Znojmo). Přehled výzkumů 59(1), 192-193.

Laharnar, B. 2018: Metal finds, glass finds and stone moulds from the Iron Age settlement at Most na Soči. In: J. Dular, S. Tecco Hvala (ur.): Železnodobno naselje Most na Soči. Razprave. Opera Instituti archaeologici Sloveniae 34. Ljubljana: Inštitut za arheologijo, 195-247.

Łuczkiewicz, P., Schönfelder, M. 2008: Untersuchungen zur Ausstattung eines späteisenzeitlichen Reiterkriegers aus dem südlichen Karpaten- oder Balkanraum. Jahrbuch des Römisch-Germanisches Zentralmuseums 55, 158-210.

Lutz, J. 1998: Röntgenfluoreszenzanalyse (RFA). In: H.-U. Voss, P. Hammer, J. Lutz: Römische und germanische Bunt- und Edelmetallfunde im Vergleich: Archäometallurgische Untersuchungen ausgehend von elbgermanischen Körpergrabern. Bericht der Römisch-Germanischen Kommission 79, 169-172.

Macháček, J. 2001: Zpráva o archeologickém výzkumu Břeclav Líbivá 1995-1998. In: Z. Měřínský (ed.): Konference Pohansko 1999. 40 let od zahájení výzkumu slovanského hradiska Břeclav-Pohansko. Břreclav-Pohansko 3.-4. 6. 1999. Archaeologia mediaevalis Moravica et Silesiana I/2000. Brno: Masarykova univerzita v Brně, 39-62.

Mangel, T., Jošková, T. 2019: East Bohemian finds of belt segments with a central knob and side plates as evidence of interregional contacts during the La Tène period. Studia Historica Nitriensia 23, Supplementum, Sedem kruhov Josefa Bujnu. Nitra: Univerzita Konštantína Filozofa v Nitre, 465-480.

Meduna, J. 1961: Staré Hradisko. Katalog nálezů uložených v muzeu města Boskovic. Fontes Archaeologiae Moravicae II. Brno: Archeologický ústav AV ČR, Brno.

Meduna, J. 1980a: Die latènezeitlichen Siedlungen in Mähren. Praha: Academia Praha.

Meduna, J. 1980b: Die latènezeitlichen Siedlungen und Gräberfelder in Mähren (Katalog). Fontes Archaeologiae Moravicae XI. Praha: Archeologicky ústav ČSAV.

Meduna, J. 1997: Latènezeit. In: L. Poláček (Hrsg.): Studien zum Burgwall von Mikulčice. Band II. Spisy Archeologického ústavu AV ČR Brno 7. Brno: Archäologisches Institut der Akademie der Wissenschaften der Tschechischen Republik Brno, 249-275.

Militký, J. 2015: Oppidum Hradiště u Stradonic. Komentovaný katalog mincovních nálezů a dokladi̊ mincovní výroby. Praha: Abalon, Archeologický ústav AV ČR, Praha, v. v. i.

Militký, J. 2018a: Celtic coins from the central site of Žehuň. Památky archeologické CIX, 179-231.

Militký, J. 2018b: Keltské mincovnictví ve 3. a 2. století pred Kristem $v$ Čechách. Praha: Archeologický ústav AV ČR, Praha, v. v. i.

Moosleitner, F., Pauli, L., Penninger, E. 1974: Der Dürrnberg bei Hallein II. Katalog der Grabfunde aus der Hallstatt- und Latènezeit. Zweiter Teil. Münchner Beiträge zur Vor- und Frühgeschichte 17. München: Beck.

Novotný, B. 1963: Výzkum velkomoravského hradiště „Pohanska“ u Nejdku na lednickém ostrově. Památky archeologické LIV, 3-40. 
Paulsen, R. 1933: Die Münzprägungen der Boier. Leipzig, Wien: Verlag Heinrich Keller, Anton Schroll \& Co.

Penninger, E. 1972: Der Dürrnberg bei Hallein I. Katalog der Grabfunde aus der Hallstatt- und Latènezeit. Erster Teil. Münchner Beiträge zur Vor- und Frühgeschichte 16. München: Beck.

Píč, J. L. 1906: Le Hradischt de Stradonitz en Bohême. Leipzig: Hiersemann.

Pieta, K. 2008: Keltské osídlenie Slovenska. Mladšia doba laténska. Archaeologica Slovaca Monographiae Studia XI. Nitra: Archeologický ústav SAV v Nitre.

Pieta, K. 2010: Die keltische Besiedlung der Slowakei. Jüngere Latènezeit. Archaeologica Slovaca Monographiae, Studia XII. Nitra: Archeologický ústav SAV v Nitre.

Pieta, K. 2018: Ein mittellatènezeitlicher Brandopferplatz in Slatina nad Bebravou. Študijné zvesti Archeologického ústavu Slovenskej akadémie vied Nitra 64, 2018, 89-113.

Pink, K. 1974: Die Münzprägung der Ostkelten und ihrer Nachbarn. Braunschweig: Klinkhardt \& Biermann.

Pollard, A. M., Bray, P. 2014: Chemical and Isotopic Studies of Ancient Metals. In: B. W. Roberts, C. P. Thornton (eds.): Archaeometallurgy in Global Perspective. Methods and Syntheses. New York: Springer, 217-238.

Rams1, P. C. 2011: Das latènezeitliche Gräberfeld von Mannersdorf am Leithagebirge, Flur Reinthal Süd, Niederösterreich. Studien zu Phänomenen der latènezeitlichen Kulturausprägungen. Mitteilungen der Prähistorischen Kommission 74. Wien: Austrian Academy of Sciences.

Salač, V. 2014: Oppida und Urbanisation Processes in Central Europe. In: M. Fernández-Götz, H. Wendling, K. Winger (eds.): Paths to Complexity. Centralisation and Urbanisation in Iron Age Europe. Hawertoven: Oxbow Books, 64-75.

Ščasnár, V., Kliment, V., Červeňanský, M., Zachar, L. 1984: Zlomky dávkovacích platničiek na výrobu keltských mincí - nálezy zo Šaštína-Stráźí a Bratislavy. Slovenská numizmatika 8, 121-145.

Schönfelder, M. 2002: Das spätkeltische Wagengrab von Boé. Studien $z u$ Wagen und Wagengräbern der jüngeren Latènezeit. Monographien des Römisch-Germanisches Zentralmuseums 84. Mainz: Verlag des Römisch-Germanischen Zentralmuseums.

Škojec, J. 2000: Archäologische Fundstätten und Funde im „Hinterland“ des Burgwalls von Mikulčice IV (Katastralgebiete Čejkovice, Dolní Bojanovice, Josefov, Nový Poddvorov, Petrov, Prušánky, Starý Poddvorov, Strážnice, Sudoměřice, Vnorovy). In: L. Poláček (Hrsg.): Studien zum Burgwall von Mikulčice. Band IV. Spisy Archeologického ústavu AV ČR Brno 18. Brno: Archäologisches Institut der Akademie der Wissenschaften der Tschechischen Republik Brno, 405-495.

Smělý, T. 2017a: Numismatische Spur des bislang verkannten Siedlungszentrums in der Region von Břeclav, Südmähren. In: J. Kysela, A. Danielisová, J. Militký (eds.): Stories that made the Iron Age. Studies in Iron Age Archaeology dedicated to Natalie Venclová. Praha: Institute of Archaeology of the Czech Academy of Sciences, v. v. i., Charles University, Faculty of Arts, 505-521.

Smělý, T. 2017b: One Authority - One Idea - One Order. The Monetary System of the Amber Road as a Testimony of Greek Influence on Social and Economic Activities of central European Celts. Studia Hercynia 21(2), 40-80.

Soják, M., Fecko, P. 2019: K niektorým novým nálezom z doby laténskej na Spiši. In: L. Benediková, G. Březinová, E. Horváthová, S. Stegmann-Rajtár (eds.): Fragmenty času. Venované Elene Miroššayovej k 70. narodeninám. Študijné zvesti Archeologického ústavu Slovenskej akadémie vied, Supplementum 1/2019. Nitra: Archeologický ústav SAV v Nitre, 451-462.

Soudská, E. 1994: Die Anfänge der keltischen Zivilisation in Böhmen. Das Gräberfeld Manětín-Hrádek. Praha: Krystal OP.
Tajer, A. 2009: Nález laténského bronzového opasku z lokality Hulín 1. In: M. Bém, J. Peška (eds.): Ročenka 2008. Olomouc: Archeologické centrum Olomouc, 172-183.

Tappert, C. 2019: Straubing „Sorviodurum“ - Entwicklung eines keltischen Zentralortes an der Donau. In: S. Fichtl, P. Barral, G. Pierrevelcin, M. Schönfelder (dir.): Les agglomérations ouvertes de l'Europe celtique (III $I^{e} I^{e r}$ s. av. J.-C.). Table ronde internationale. Glux-en-Glenne, 28, 29 et 30 octobre 2015. Mémoires d'Archéologie du Grand Est 4. Strasbourg: Avage, 349-366.

Tappert, C., Mielke, D. P. 1998: Eine kleine syrische Bronzesitula aus frühkeltischer Zeit. Jahresbericht des Historischen Vereins für Straubing und Umgebung 99/1997, 15-31.

Teßmann, B. 2007: Körbchenanhänger im Süden - Göritzer Bommeln im Norden. Eine vergleichende Studie zu einem spätrepublikanischen Anhängertyp. Situla 44, 667-694.

Teuber, S. 2017: Das Brandgräberfeld der Spätlatènezeit und älteren Römischen Kaiserzeit bei Einbeck, Landkreis Northeim. In: Ch. Rinne, J. Reinhard, E. R. Heege, S. Teuber (Hrsg.): Vom Bodenfund zum Buch. Archäologie durch die Zeiten. Festschrift für Andreas Heege. Historische Archäologie Sonderband 1. Bonn: Habelt, 91-142.

Torbágyi, M. 1998: Bemerkungen zur Chronologie der keltischen Münzen vom Kapostaler Typ. In: U. Peter (Hrsg.): Stephanos nomismatikos. Edith Schönert-Geiss zum 65. Geburtstag. Griechisches Münzwerk. Berlin: Akademie Verlag, 631-642.

Trebsche, P. 2014: Size and economic structure of La Tène period lowland settlements in the Austrian Danube region. In: S. Hornung (Hrsg.): Produktion - Distribution - Ökonomie. Siedlungs- und Wirtschaftsmuster der Latènezeit. Akten des internationalen Kolloquiums in Otzenhausen, 28.-30. Oktober 2011. Universitätsforschungen zur prähistorischen Archäologie 258. Bonn: Verlag Dr. Rudolf Habelt GmbH, 341-373.

Trebsche, P. 2019: Die latènezeitlichen Großsiedlungen im österreichischen Donauraum - Forschungsstand, Typologie und Überlegungen zur Genese. In: S. Fichtl, P. Barral, G. Pierrevelcin, M. Schönfelder (dir.): Les agglomérations ouvertes de l'Europe celtique (III $-^{e} I^{e r}$ s. av. J.-C.). Table ronde internationale. Glux-en-Glenne, 28, 29 et 30 octobre 2015. Mémoires d'Archéologie du Grand Est 4. Strasbourg: Avage, 367-388.

Trebsche, P., Fichtl, S. 2016a: Das keltische Siedlungszentrum von Haselbach. Die französisch-österreichischen Ausgrabungen 2015-2016. Archäologie Österreichs 27(2), 2-17.

Trebsche, P., Fichtl, S. 2016b: Die latènezeitliche Zentralsiedlung von Haselbach (Gemeinde Niederhollabrunn) - zum Beginn des französisch-österreichischen Forschungsprojektes. In: E. Lauermann, P. Trebsche (Hrsg.): Beiträge zum Tag der Niederösterreichischen Landesarchäologie 2016. Tag der Niederösterreichischen Landesarchäologie. Asparn/Zaya: Donau Universität Krems, MAMUZ Schloss Asparn/Zaya, 20-36.

Venclová, N. 1990: Prehistoric glass in Bohemia. Praha: Archeologický ústav ČSAV.

Venclová, N. 2016: Němčice and Staré Hradisko. Iron Age glass and glass-working in Central Europe. Praha: Archeologický ústav AV ČR, Praha, v. v. i.

Venclová, N., Militký, J. 2014: Glass-making, coinage and local identities in the Middle Danube region in the third and second centuries B.C. In: S. Hornung (Hrsg.): Produktion - Distribution Ökonomie. Siedlungs- und Wirtschaftsmuster der Latènezeit. Akten des internationalen Kolloquiums in Otzenhausen, 28.-30. Oktober 2011. Universitätsforschungen zur prähistorischen Archäologie 258. Bonn: Verlag Dr. Rudolf Habelt GmbH, 387-406.

Vích, D. 2017: Doba laténská v severní části Boskovické brázdy ve světle drobných kovových nálezů. Archeologické rozhledy LXIX(4), 629-671. 
Waldhauser, J., Krásný, F. 2006: Problémy konce doby laténské v Pojizeří. In: E. Droberjar, M. Lutovský (eds.): Archeologie barbarů 2005. Sborník př́spěvků z I. protohistorické konference „Pozdně keltské, germánské a časně slovanské osídlení“ (Kounice, 20.-22. zář́i 2005). Praha: Ústav archeologické památkové péče středních Čech, 91-155.

Werner, W. M. 1988: Eisenzeitliche Trensen an der unteren und mittleren Donau. Prähistorische Bronzefunde XVI(4). München: Beck.

\section{Resumé}

Ačkoliv Břeclavsko a region pod Pavlovskými vrchy jsou díky mnohaletým záchranným výzkumům, předcházejícím stavbu Novomlýnských nádrží, považovány za jednu z nejlépe prozkoumaných oblastí na Moravě, nové detektorové nálezy podstatně mění pohled na osídlení regionu v době laténské. Předkládaná studie představuje 70 drobných laténských předmětů z detektorových prospekcí, zapůjčených v roce 2020 ze studijního sbírkového fondu Střediska pro výzkum doby římské a stěhování národů Archeologického ústavu AV ČR, Brno, v. v. i, pro výstavu Keltové pod Pálavou v Regionálním muzeu v Mikulově.

Studovaný soubor čítá 47 předmětů ze slitin mědi (lidské figurky, součásti opasků, závěsky a „amulety“), 18 mincí a 5 skleněných předmětů ze 17 katastrů okresů Břeclav, Hodonín a Brno-venkov; u kovových artefaktů byla provedena analýza prvkového složení.

V souboru jsou zastoupeny výhradně předměty z LT C-D. Většina nálezů se zřejmě časově překrývá s dobou rozkvětu aglomerace v Němčicích nad Hanou v LT C1-C2, kde nacházíme paralely pro antropomorfní figurky, součásti opasků, skleněné náramky a pro část Knotenringe a mincí. Mladší předměty, které se jinak vyskytují spíse na oppidech v LT (C2)-D1, jsou v souboru spíse výjimkou (prstencový korál z Mikulova - Na Mikulovsku, mince z Horních Věstonic, Přítluk a Pasohlávek).

Některé lokality na katastru Mikulova, Břeclavi a Hrušek se nacházejí blízko u sebe a vytvářejí jakési shluky lokalit s obdobným spektrem kovových nálezů, datovaných převážně do LT C-D1. Není zatím jasné, jaké místo zaujímají tyto koncentrace lokalit v běžné sídelní strategii komunit v době laténské (nejen) na Moravě. Mohou odpovídat věnci sídlišť okolo centrálních lokalit nebo „aglomeracím“ v jiném slova smyslu, tvořeným seskupením sídlišt̃. Na Břeclavsku dosud postrádáme spolehlivě lokalizované regionální centrum, které by počtem nálezů vysoce přesahovalo průměrná sídliště (přesné místo nálezu dříve publikovaného souboru velkého počtu mincí z okolí Břeclavi dosud neznáme).
Předkládaný soubor ale jasně ukazuje, že některé lokality na Břeclavsku mají ve srovnání s regionálními centry typu Žehuň nižší kvantitu, ale ne kvalitu kovových nálezů. V budoucnu by bylo tedy vhodné věnovat pozornost nejen samotným centrům typu Němčice/Roseldorf (či stř̌edně velkým sídlištím typu Žehuň), ale i shlukům okolních lokalit a řešit otázky vztahu sídlišt k centru a k sobě navzájem (např. subsistence, distribuce produktů).

\section{Contacts}

\section{Petra Goláňová}

Ústav archeologie a muzeologie,

Filozofická fakulta, Masarykova univerzita

Arna Nováka 1

CZ-602 00 Brno

golanova@phil.muni.cz

\section{Balázs Komoróczy}

Archeologický ústav AV ČR, Brno, v. v. i.

Čechyňská 19

CZ-602 00 Brno

komoroczy@arub.cz

\section{Matěj Kmošek}

Archeologický ústav AV ČR, Brno, v. v. i. Čechyňská 19

CZ-602 00 Brno

kmosek@arub.cz

\section{Eva Kolníková}

Výstavná 17

SK-949 01 Nitra

titusaeva@gmail.com

\section{Marek Vlach}

Archeologický ústav AV ČR, Brno, v. v. i. Čechyňská 19

CZ-602 00 Brno

vlach@arub.cz

\section{Michaela Zelíková}

Archeologický ústav AV ČR, Brno, v. v. i.

Čechyňská 19

CZ-602 00 Brno

zelikova@arub.cz 
